\title{
الآثار القانونية لعقد الإشراف على البناء
}

\author{
إعداد
}

عبدالرحمن بن محمد عبدالرحمن الزير

الأستاذ المساعد بقسم القانون

بالجامعة السعودية الإلكترونية 


$$
\text { - oqrr }
$$




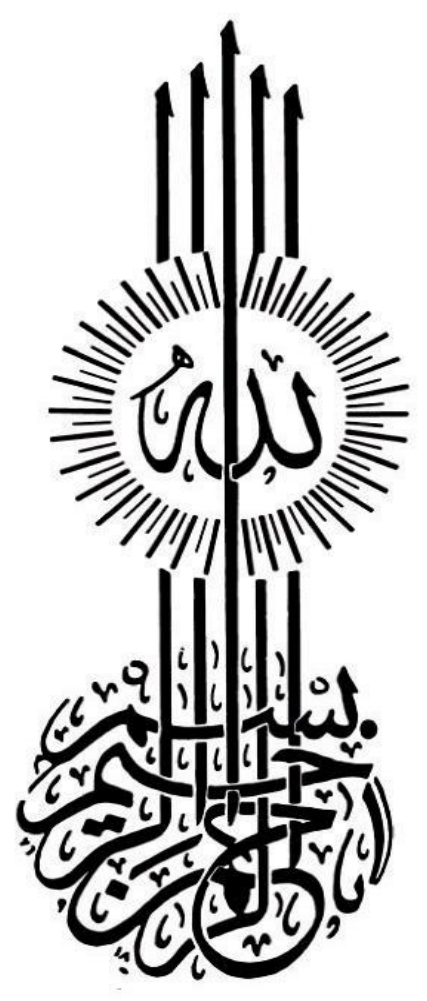




\section{الآثار القانونية لعقد الإثراف على البناء}

\section{عبدالرحمن بن محمد عبدالرحمن الزير}

قسم القانون ، الجامعة السعودية الإلكترونية ، المملكة العربية السعودية .

\section{dr.a.m.alzeer@gmail.com: البريد الإكتروني}

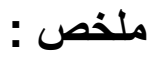

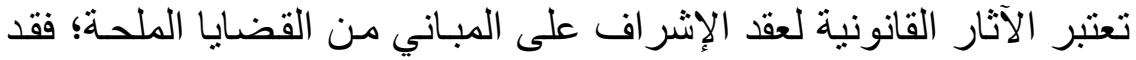

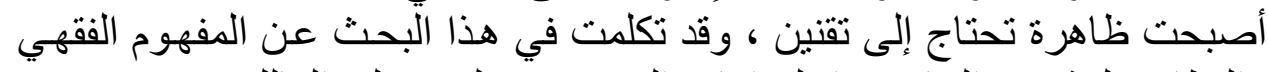

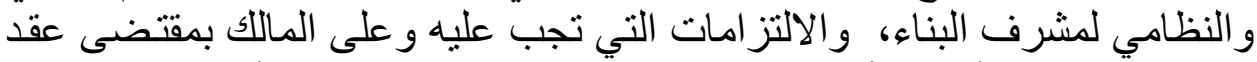

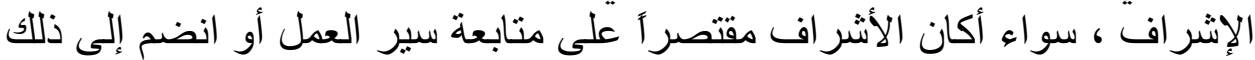

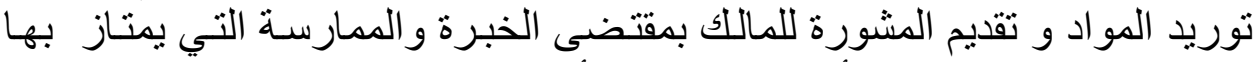

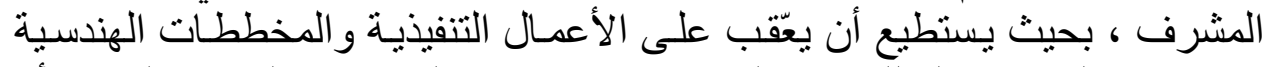

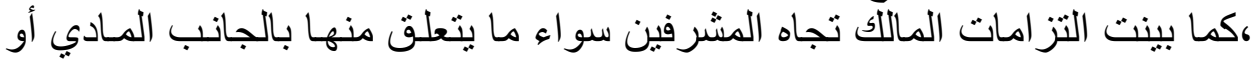

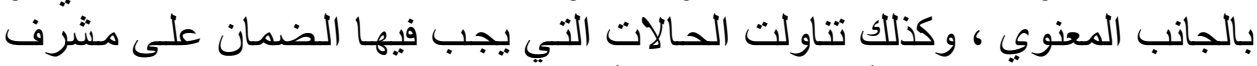

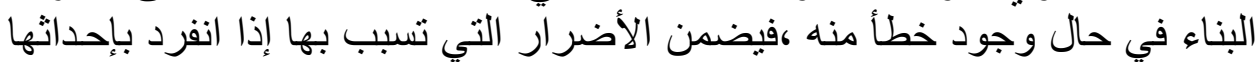

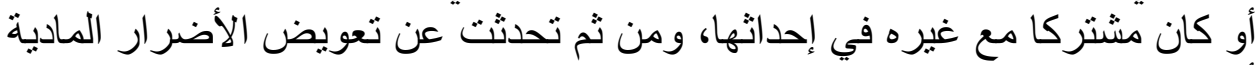

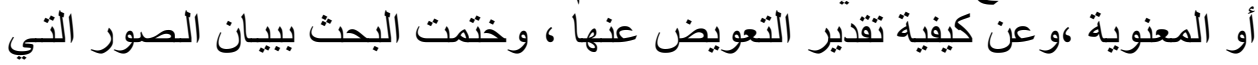
ينقضي بها عقد الإشر اف.

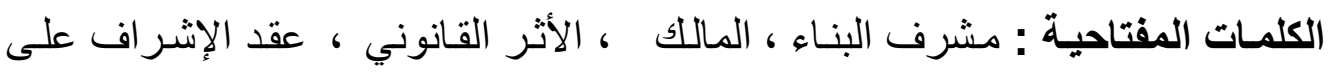

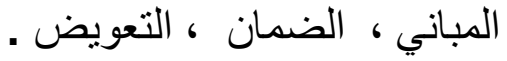




\section{Legal implications of the construction supervision contract}

\section{Abdul Rahman bin Mohammed Abdul Rahman Al-Zeer}

Law Department, Saudi Electronic University, Kingdom of Saudi Arabia.

\section{E-mail : dr.a.m.alzeer@gmail.com}

\section{Abstract:}

The legal implications of the supervision of buildings contracts are a pressing issue, as it becomes a phenomenon, need to be legalized.

In this research, I discussed the jurisprudential and legal concept of the construction supervisor, his obligations, and the owner obligations under the supervision contract, whether the supervision is confined to following up on the workflow, the supply of materials, or guiding the owner from the perspective of the supervisor practical experience who shall be able to comment on the executive works and blueprints.

I also clarified the owner's obligations towards the supervisors, related to the material or the moral aspect. I also addressed the cases in which the construction supervisor shall be liable to make reparation for damage, caused by his actions or involved with others in causing it. Then I talked about compensation of the material or immaterial damage suffered, and how to estimate this compensation.

The research concluded with a statement of the cases in which the supervision contract expires

Key words: Construction supervisor, owner, legal effect, building supervision contract, guarantee, compensation. 


\section{مقدمة}

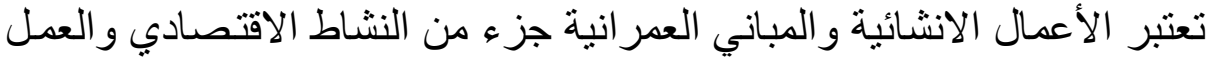

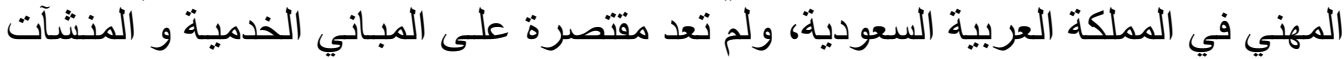

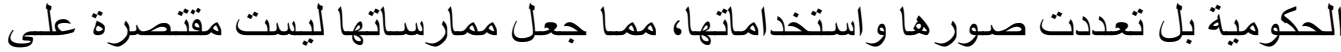

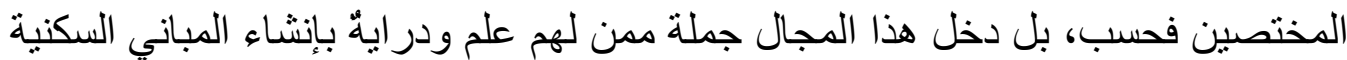

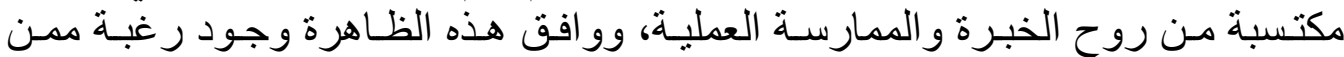

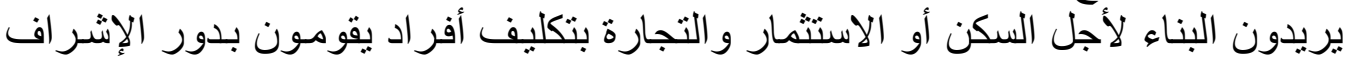

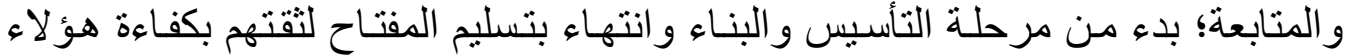

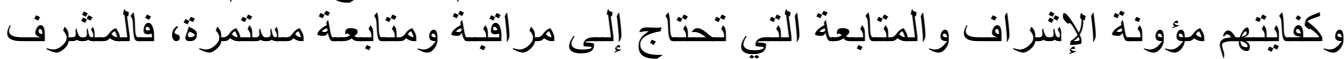

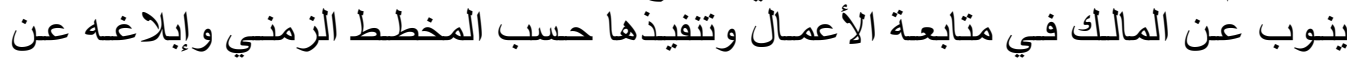

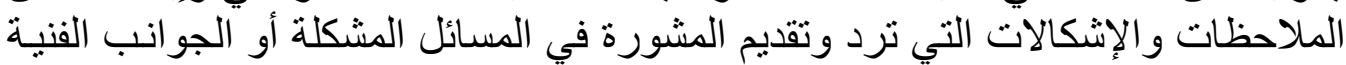

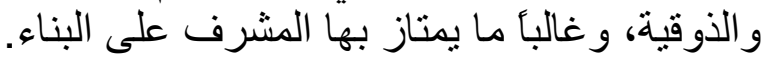

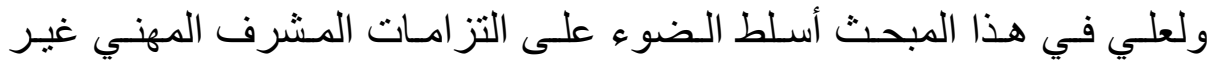

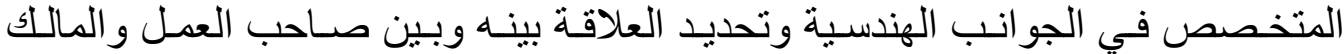

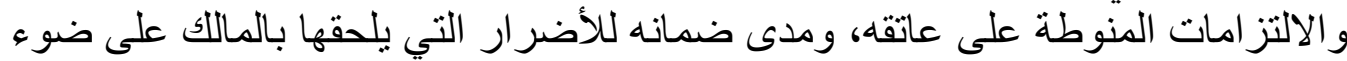

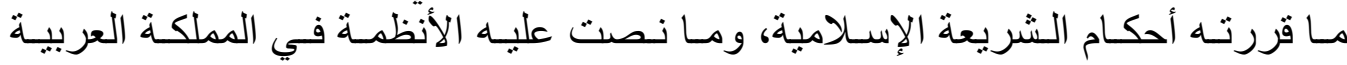
السعودية.

\section{مشكلة الار اسة:}

نظـرًا لتعدد المجـالات و المهام المطلوبـة لإتمـام عقود البنـاء والتشييد يتدخل

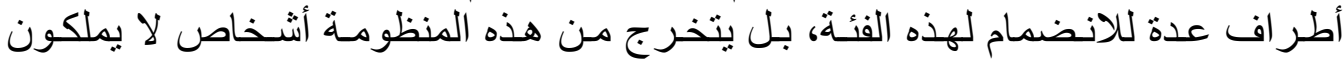

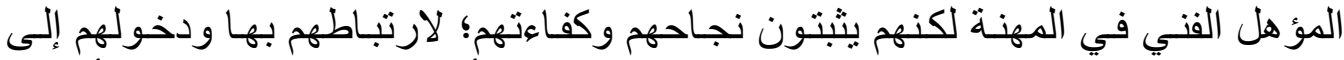

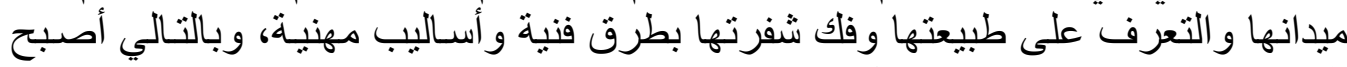
المشرف يلعب دورًا رئيسًا داخل هذه المنظومة.

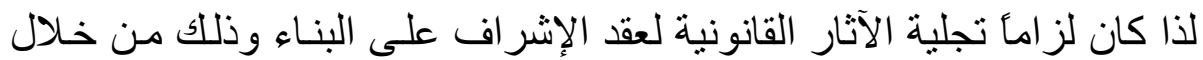

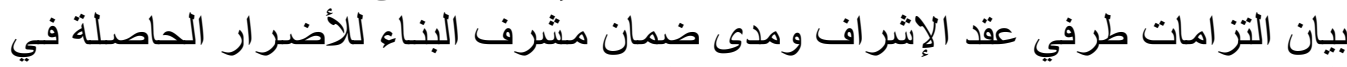

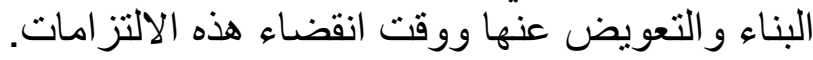

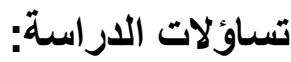

تسعى الدراسة إلى الإجابة على عدد من الأسئلة المتعلقة بالآثار القانونيـة لعقد

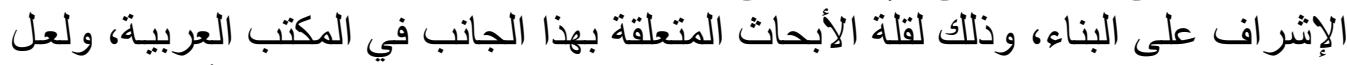
هذه الدر اسة تقدم فائدة علمية حول هذا الموضوع من خلال الإجابة على الأسئلة التالية: 1 ـ كيف يمكن تحديد الطبيعة القانونية لثخصية مشرف البناء. r- ما الفرق بين المشرف المهني و المشرف الخبير. r- ما الالتز امات التي يفترض أن يقوم بها المشرف. 
ع كيف عالج الفقه الإسلامي الأضرار الصـادرة عن مشرف البناء. 0ـ كف يتم التعويض عن هذه الأضرار. 7- كيف ينتهي عقد الإشراف.

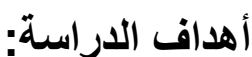

تهدف هذه الدراسة إلى تحقيق جملة من الأهداف تشتمل على ما يلي: ا ـ تحديد الإطار العام لشخصية المشرف على الشى البناء. r- تكييف عقد الأشر اف على البناء تكييفاً فقهياً. بـ تقديم المقترحات القانونية اللازمة و المنظمة لشخصية المشرف على البناء.

\section{منهجية الدراسة}

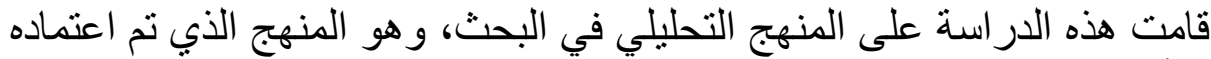

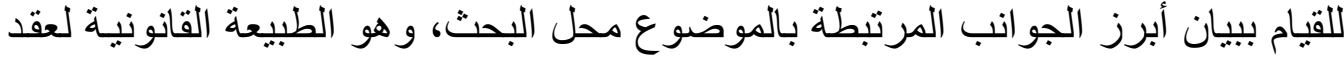
الإشراف على البناء، وما يترتب عليه من التز امات متبادلة وكيفية انتهائه.

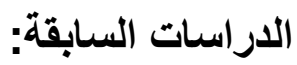

بالتأمل في الدر اسـات السابقة المرتبطة بعقد الإشر اف على الأعمـال الهندسية

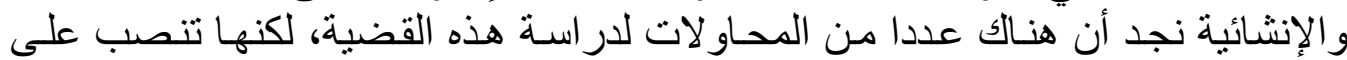

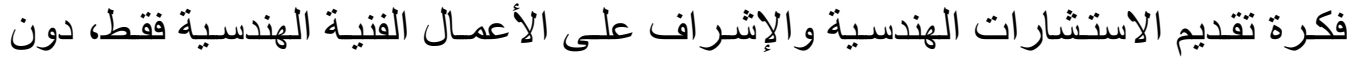

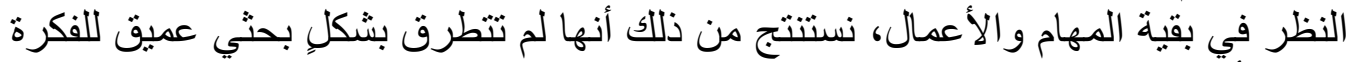

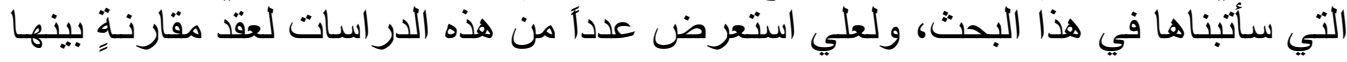
وبين البحث محلّ الدراسة:

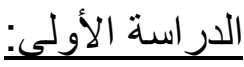

بحـث بعنـوان (المسؤولية المدنيـة للمهندس الاستشاري في عقود الإنشاءات) وقدمها الباحث هاثم علي الثهو ان. (المؤه

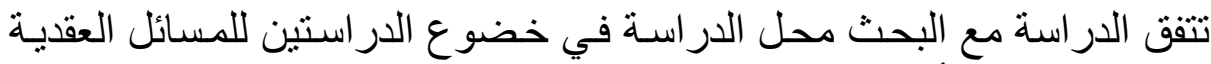
المتعلقة بفرع من فروع الأعمال الهندسية.

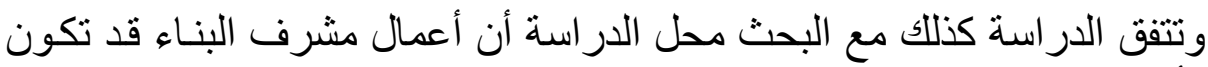

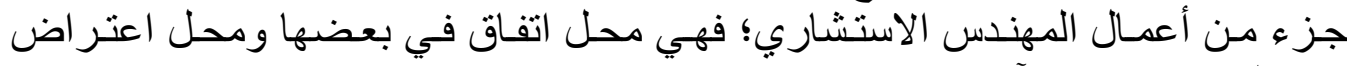

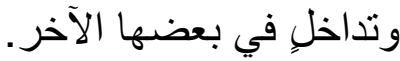

بينما الاختلاف بين هذه الدراسة والدراسة محل البحث أن:

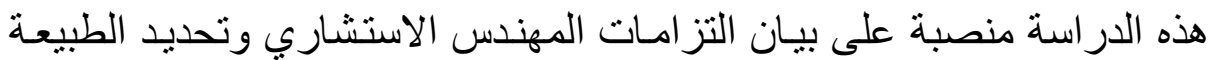

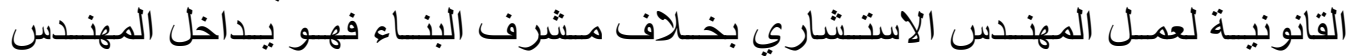

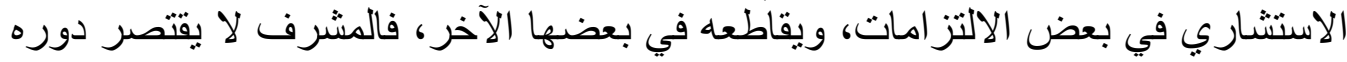




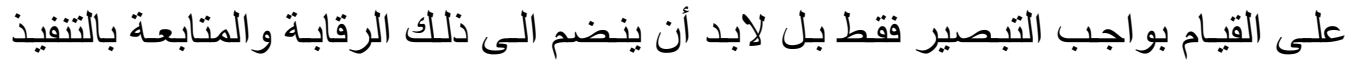
و إدارة المشروع و العاملين فيه، وهذا ما يميز هذا البحث عن الدر اسة محل المقارنة.

الدر اسة الثانية:

رسالة علمية بعنوان (مسؤولية أصحاب المهن و الحرف في الشريعة الإسـلامية

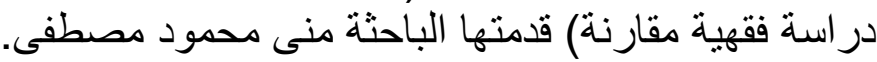

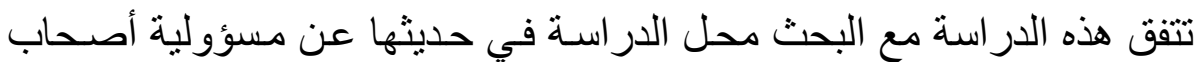

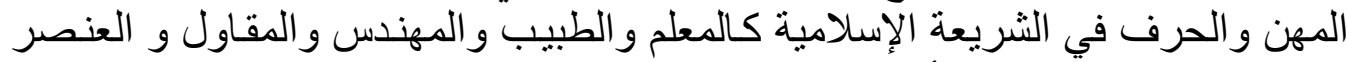

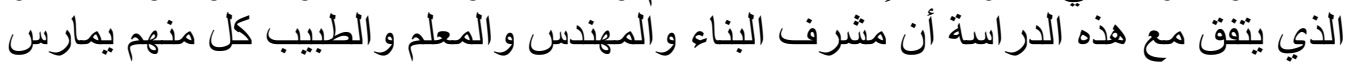

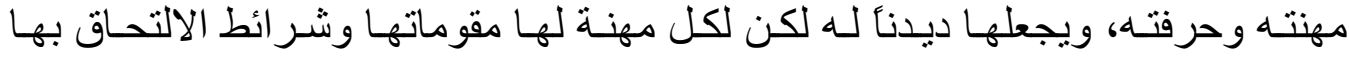

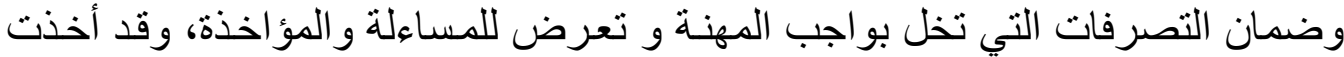

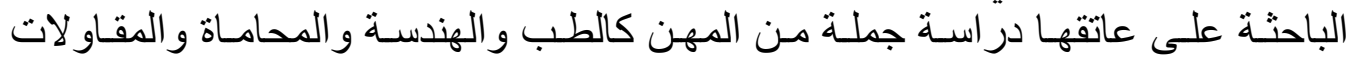

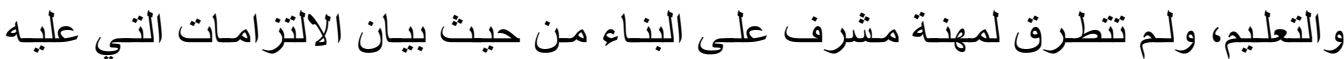

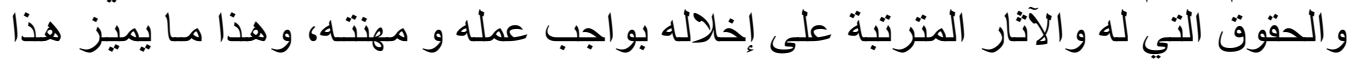
البحث عن الدر اسة محل المقارنة.

الدر اسة الثالثة:

رسالة علمية بعنو ان (المسؤولية الجنائيـة لمهندس البناء در اسـة مقارنـة) قدمها

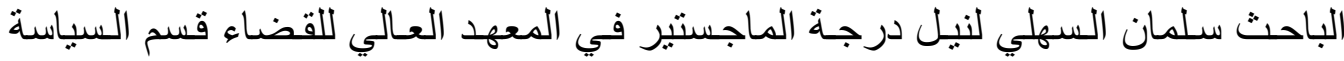

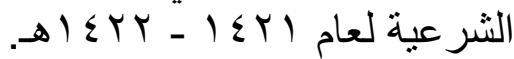

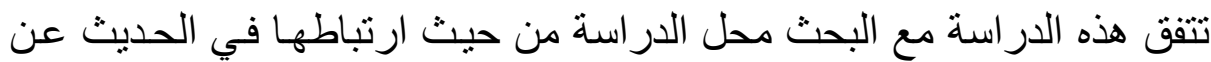

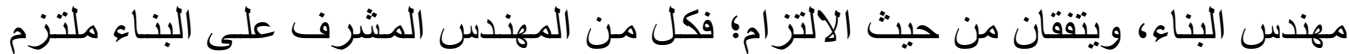

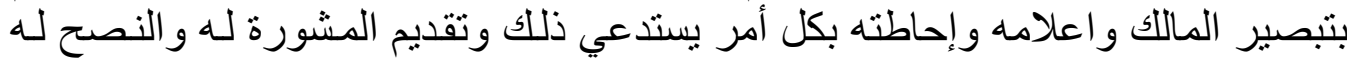

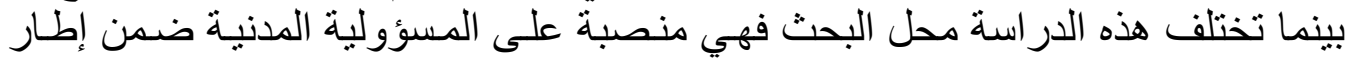

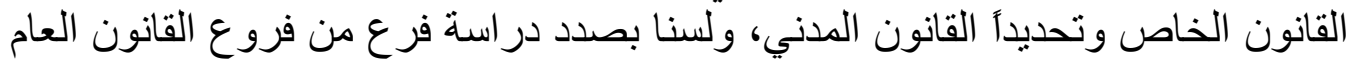
متمثلا بالمسؤولية الجنائية لمهندس البناء.

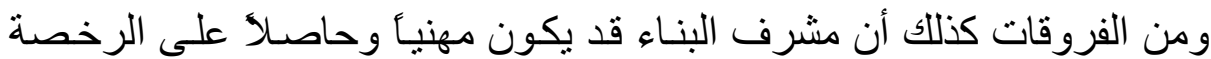

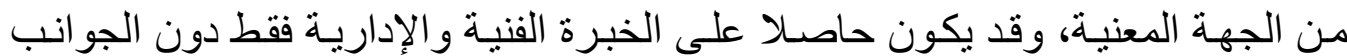
الهندسية النظرية البحتة، و هذا خارج حدود الدر اسة محل المقارنة. 


\section{خطة البحث}

المبحث الأول: المفهوم النظامي والفقهي للآثار القانونية لعقد الإشراف على البناء. المطلب الأول: المعاني اللغوية والاصطلاحية لمفردات العنوان المطلب الثاني: المفهوم النظامي والفقهي للآثار القانونية المترنبة على عقد الإشراف. المبحث الثاني: التزامات المشرف و المالك في عقد الإشر اف على المباني المطلب الأول: التزامات المشرف حال اقتصار دوره على متابعة سير العمل. المطلب الثاني: التزامات المشرف بتوريد المواد اللازمة للبناء. المطلب الثالث: التز ام المشرف بتقديم الخبرة والمشورة للمالك. المطلب الر ابع: التزامات المالك في عقد الإشراف. المبحث الثالث: مدى ضمان مشرف البناء لأفعاله وتصر فاته الضارة. المطلب الأول: أركان المسؤولية لطرفي عقد الإشر اف على المباني. المطلب الثاني: ضمان الأضرار الناتجة عن تصرفات مشرف البناء. الفرع الأول: ضمان الأضر ار حال انفر اده. الفرع الثاني: ضمان الأضرار حال اشتر اكه مع الغير في إحداثها. المبحث الر ابع: التعويض عن الضرر. المطلب الأول: التعويض عن الضرر المادي. المطلب الثاني: التعويض عن الضرر المعنوي. المطلب الثالث: تقدير التعويض. التصاب. المطلب الر ابع: انتهاء عقد الإشر اف الخاتمة تشتمل على النتائج و التوصيات.

$$
\text { -فهرس الآيات. }
$$




\section{المبحث الأول}

\section{الإفهوم النظاهي والفقهي الشرف البنـاء}

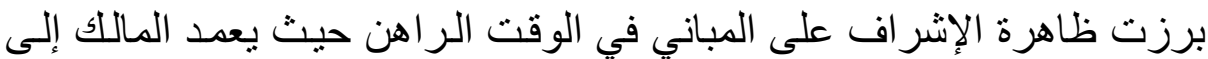

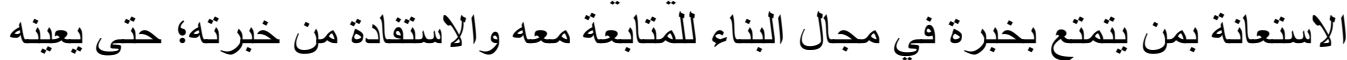

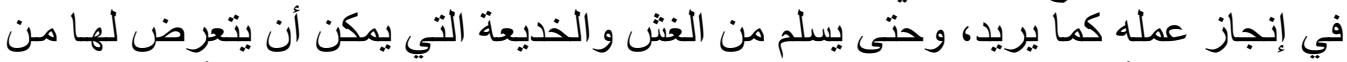

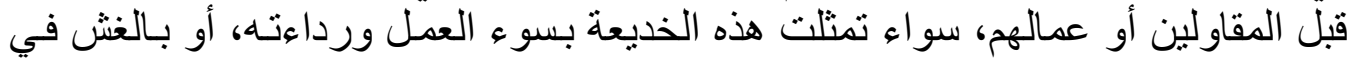
المو اد التي ينم البناء بواسطتها؛ إذ إن عيوب البناء مؤثرة، وتبقى ما بقي البناء. وقد تكلمت في هذا البحث عن الإشراف على المباني من قبل غئل غير المختصين

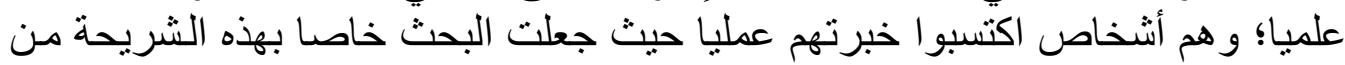

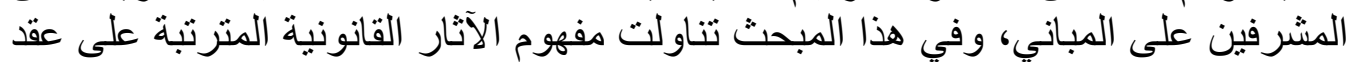

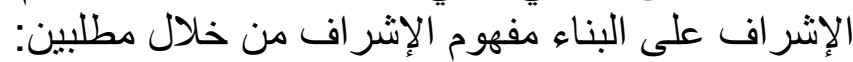

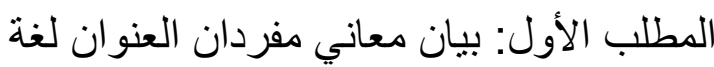
المطلب الثاني: المر اد بالآثار القانونية لمشرف دلئ البناء في النظام.

\section{المطلب الأول}

\section{المعاني اللغوية والاصطلامية لمفردات العنـوان}

لغة:

تعتبر اللغـة مهاد المعـاني الاصطلاحية فالأصل في الكلمـة أو التركيب معنـاه

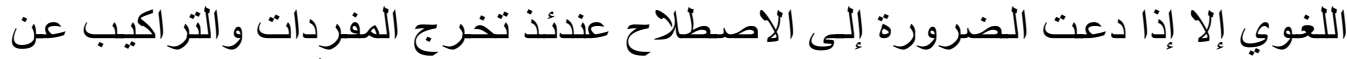

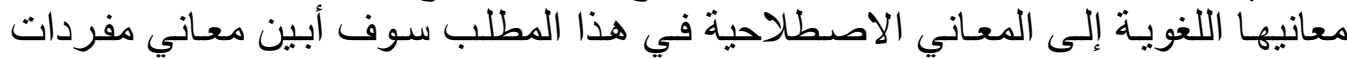

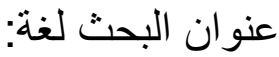

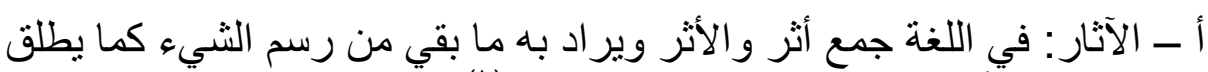

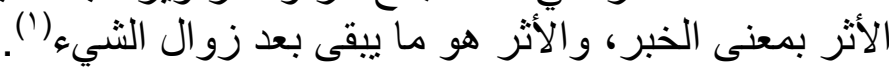

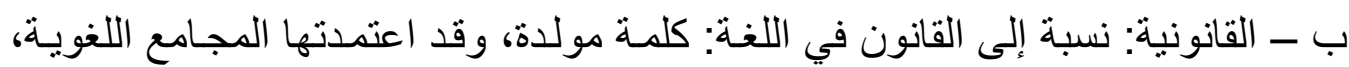

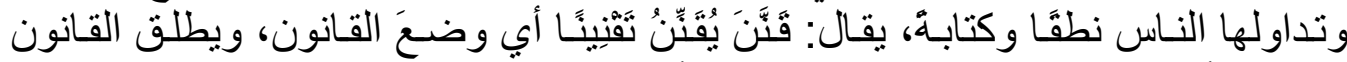

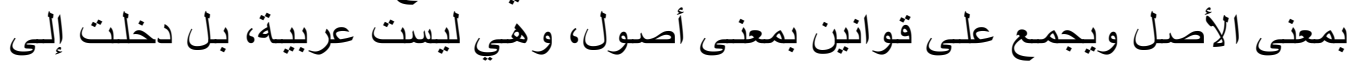
العربية قيل: من اللغة الرومانية، وقيل: من اللغة السريانية، وقيل: من اللغة العبرية. 
وذهب البعض إلى أنَّ كلمة "القانون" عربية الأصل مـادة وصيغة فمـادة قُنَّ بمعنى تنبَّعَ

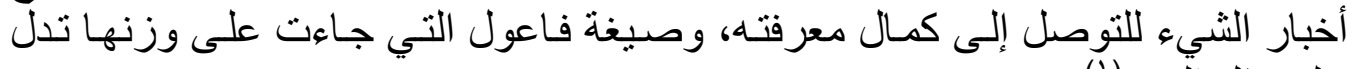

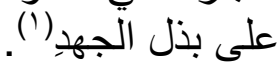
ج - المترتبة: من ترتب يترتب نرنبا أي نتبت ورتبت الثبت الثيء أي ثبته يقال رتب الشيء

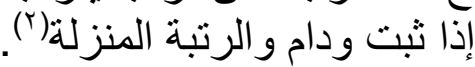

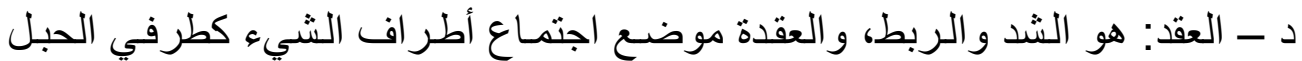

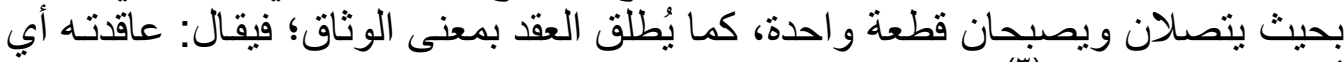
ألزمته ذلك باستيناق (ن)

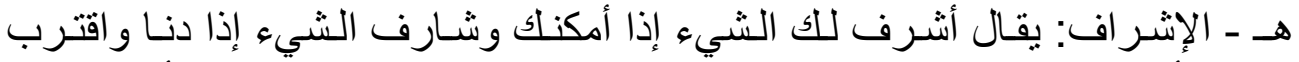

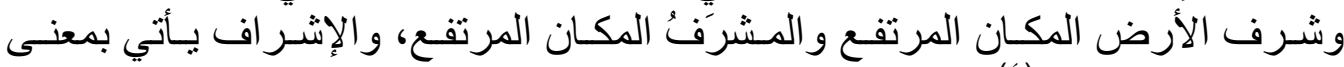

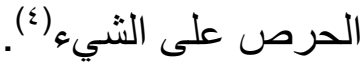

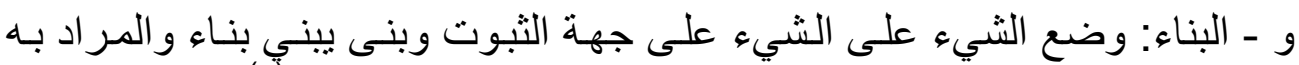

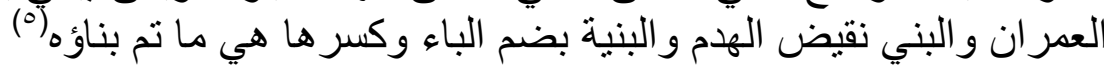

\section{1المطلب النانبي}

\section{المفهوم النظظامي والفقهي لآثار عقد الإشراف على البناء}

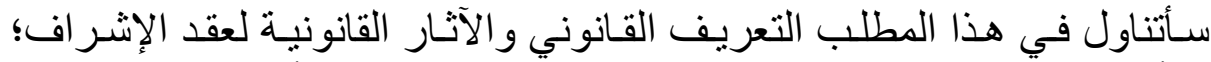

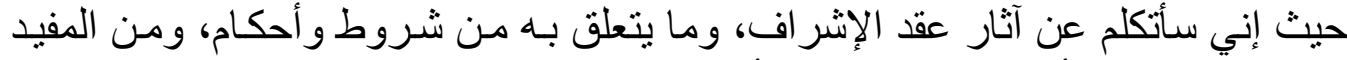

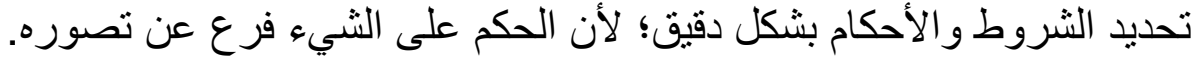

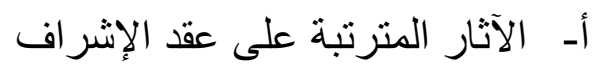

بـ القانون في الاصطلاح: لكلمة القانون في الاصطلاح ثلاثثة معاني:

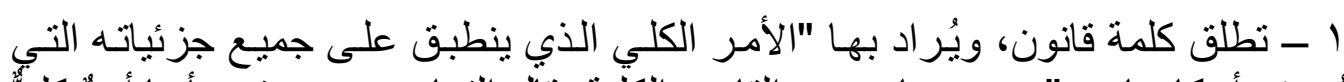

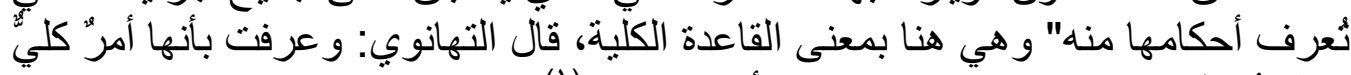

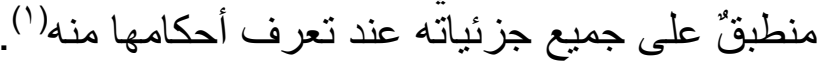

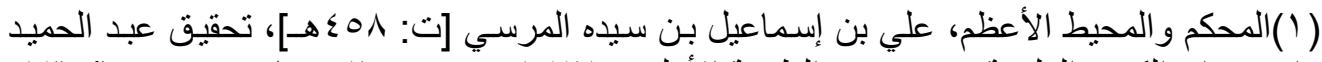

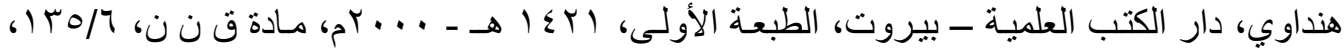

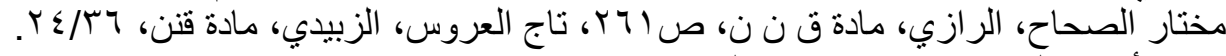

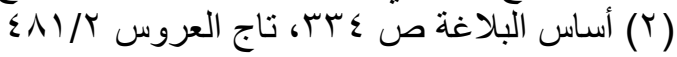

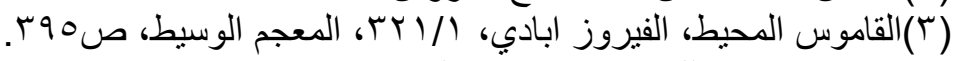

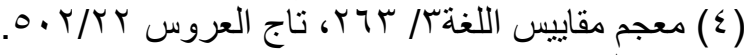




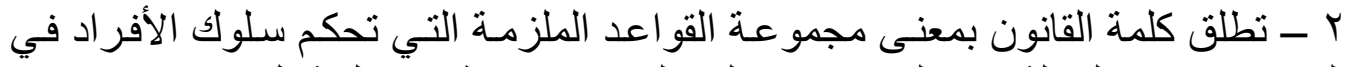

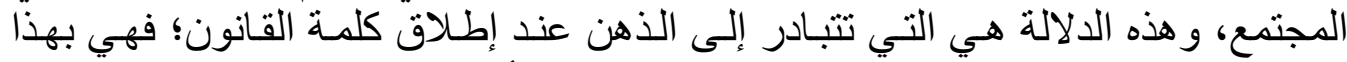

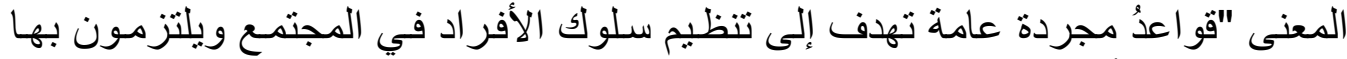

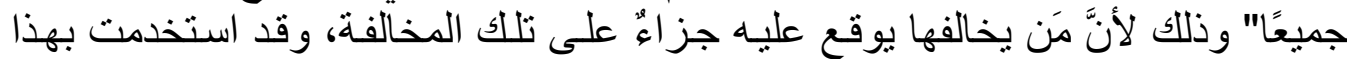

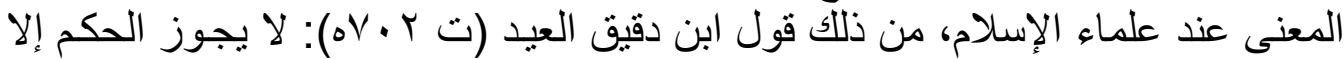

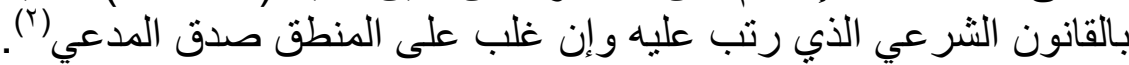

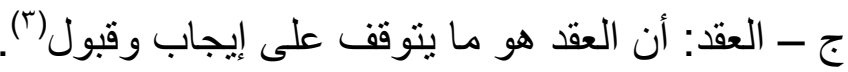

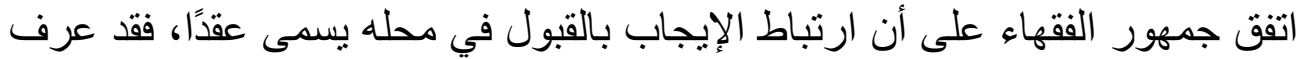

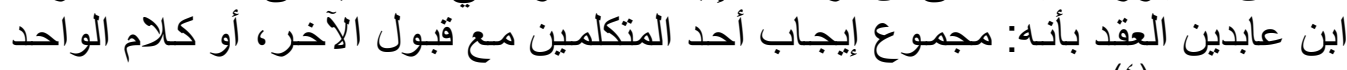

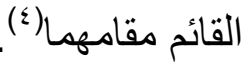

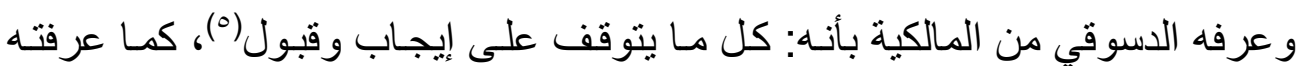

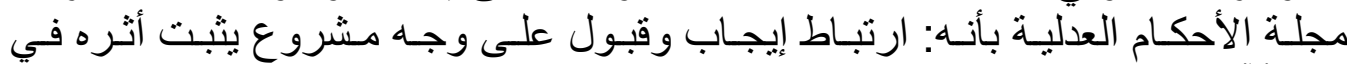
محلة) مجلة)

و ورفتـه مجلة الأحكام الحنبلية بأنه: المعاملة التي يلتزمها الطرفان بربط الإيجاب

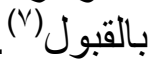

ويمكن أن يعرف بأنه: ارتباط إيجاب بقبول على وجه مشروع يظهر أثره في المحل المعقود عليه. - ان.

\section{تعريف العقد في القانون:}

عرف السنهوري العقد بأنـه: اتفـاق إر ادتين على إنشاء حق أو على نقله، أو على إنهائه(^).

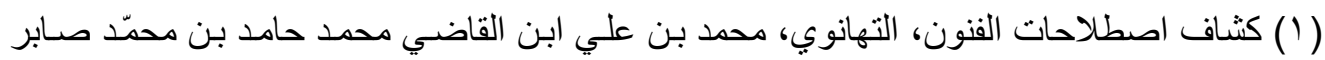

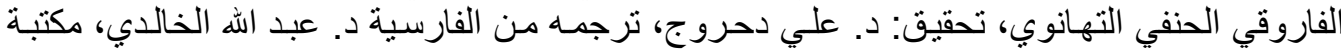

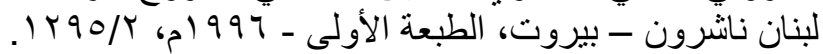

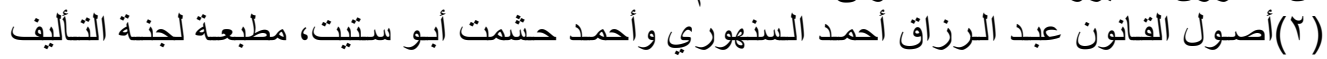

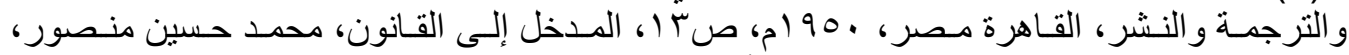

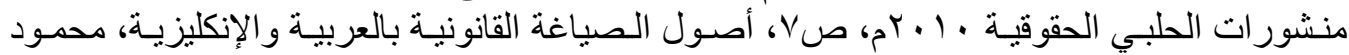

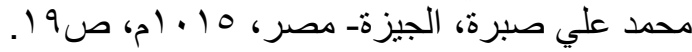

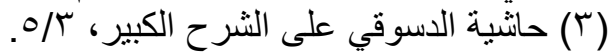

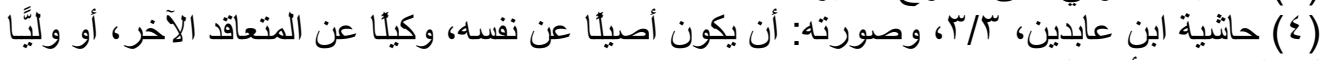
على المتعاقدين أو كينا.

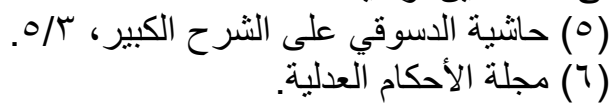

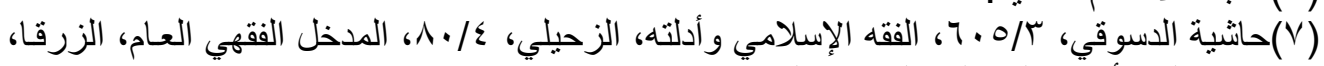

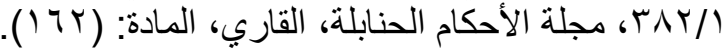


و الملاحظ أن تعريف العقد في القانون أعم و أوسـع نطاقَّا من تعريف العقد في الفقهـ

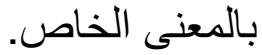

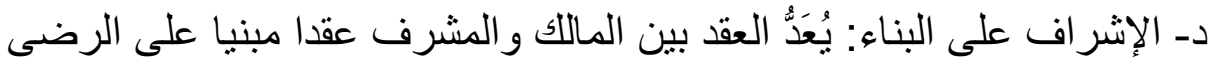

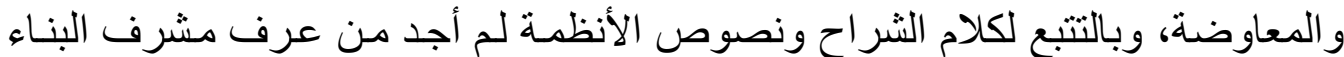

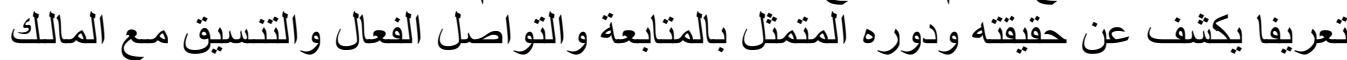

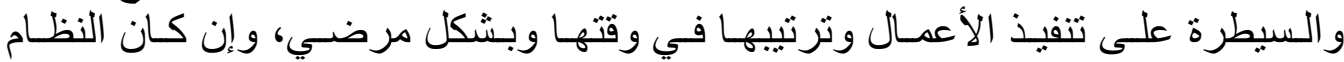

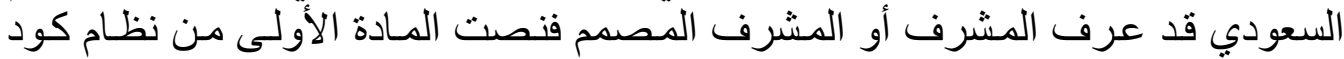

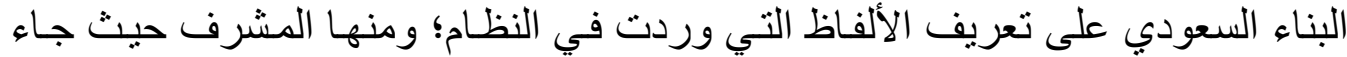
فيها:

هو الثخص ذو الصفة الطبيعية أو الاعتبارية المرخص له الذي يكلفه المالك بالقيام بأعمال الإشر اف.

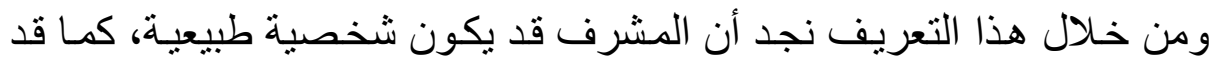

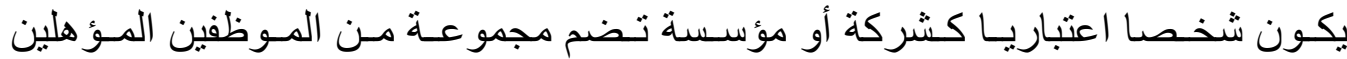

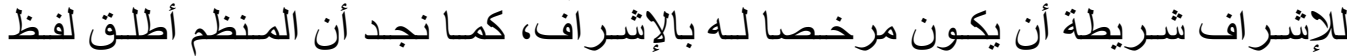

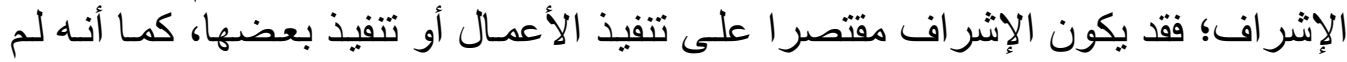

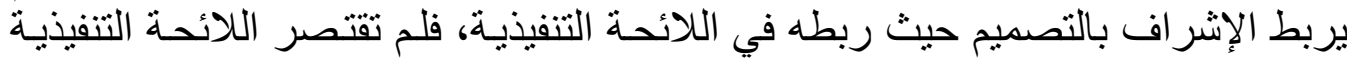

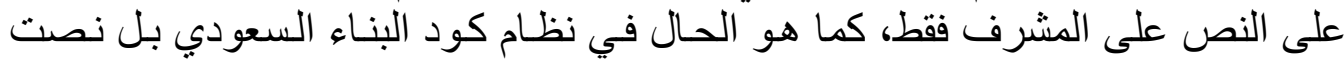

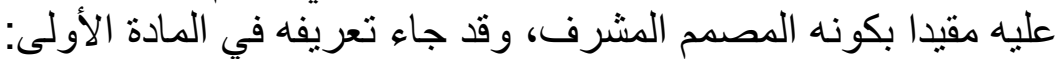

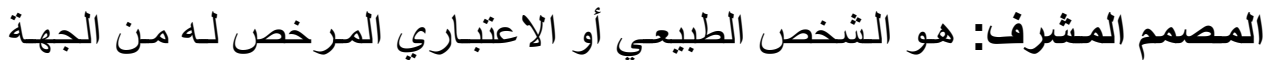

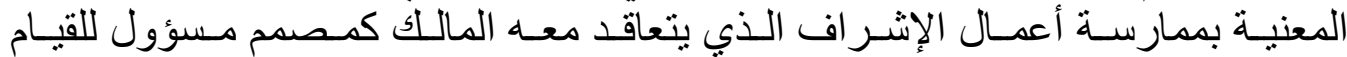

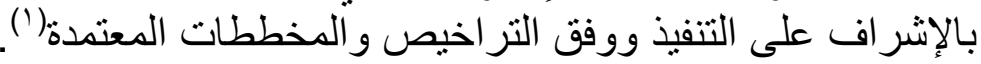

من خلال ما تقدم ذكره في النظام واللائحة وما هو معمول به في الوالهن في اقع نستنتج:

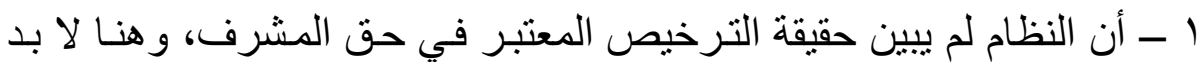

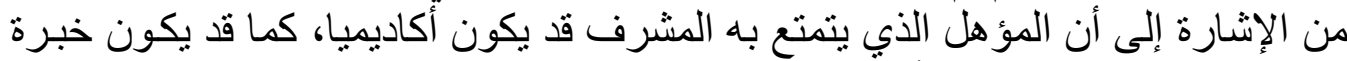

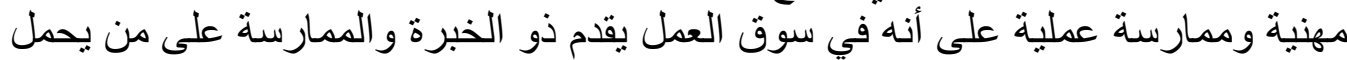

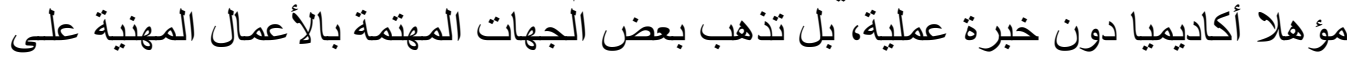

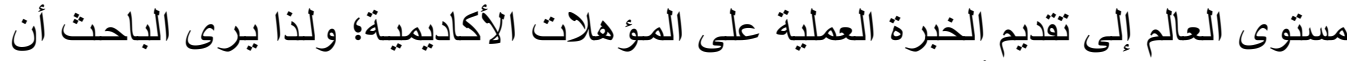

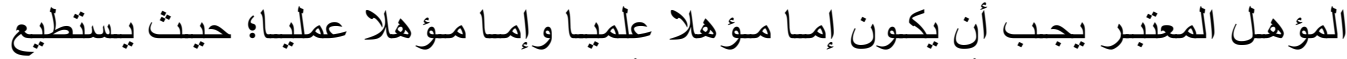

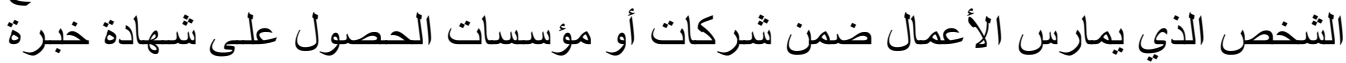

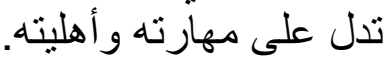

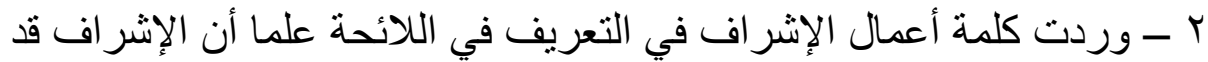

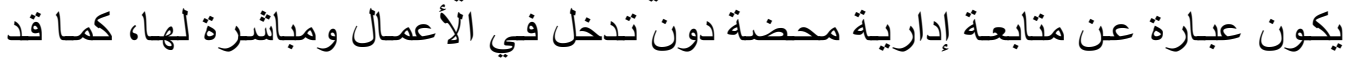


ينطوي على خبرة ودر اية و عناية ورقابـة تتعلق بصحة التنفيذ من عدمها، وليس مجرد إثر اف يقصد منه وجود التنفيذ فحسب.

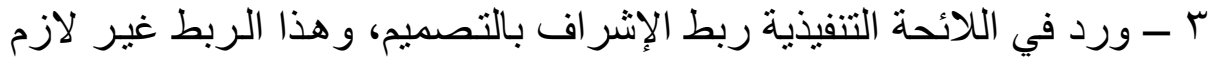

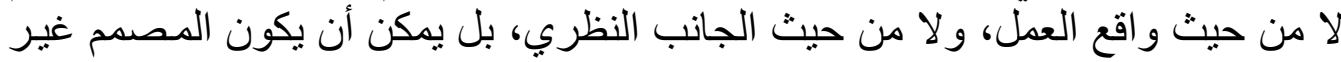

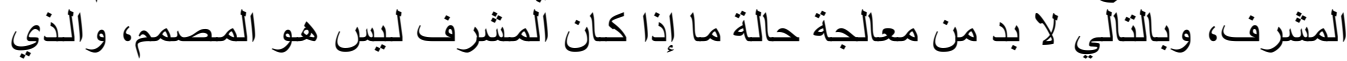

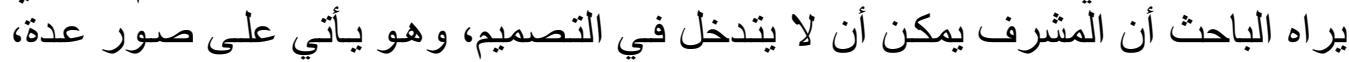

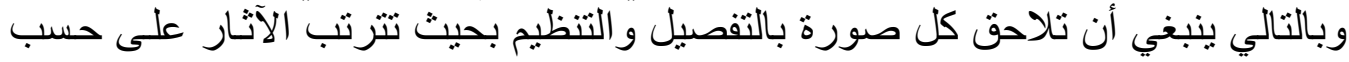

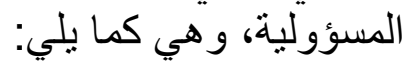

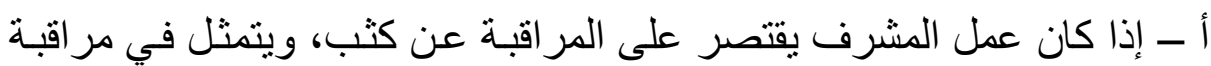

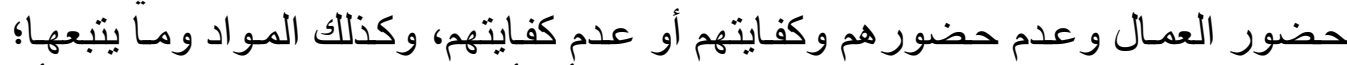

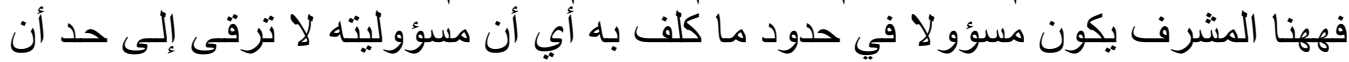

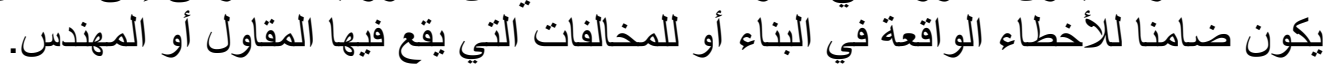

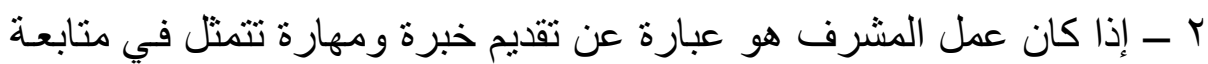

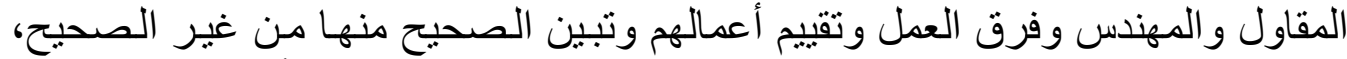

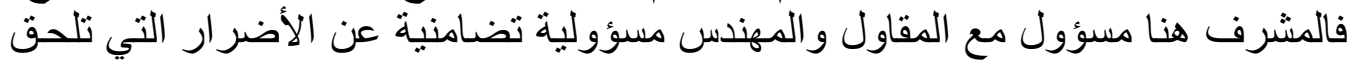

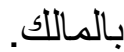

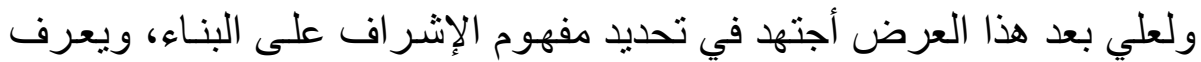

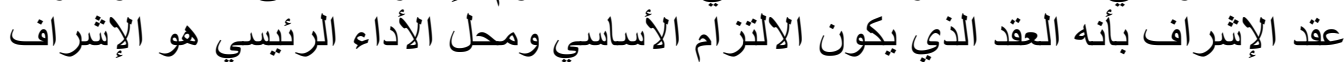
و المتابعة للبناء (')

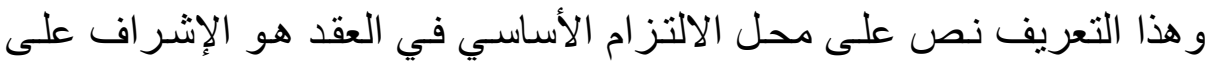

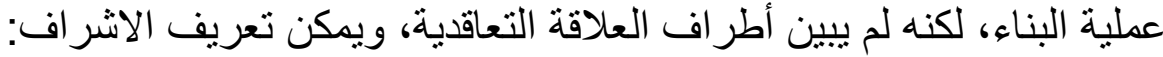
بأنه العقد الذي يلتزم المشرف بمقتضاه بمتابعة أعمال البناء والإشر اف عليها مقابل أجر لئر

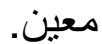

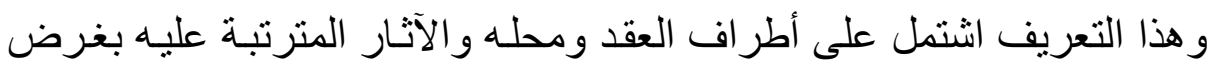
أجر معين لقاء ما قدمه من خدمة في مجاله.

( (1)سمير الأودن ، مسؤولية المهندس الاستشاري في مجـال العقود المدنيـة وعقد تسليم مفتـاح، ، 


\section{المبـث الثاني}

\section{التراهات المشرف والمالك في عقد الإشراف على البناء}

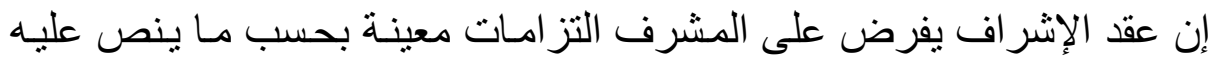

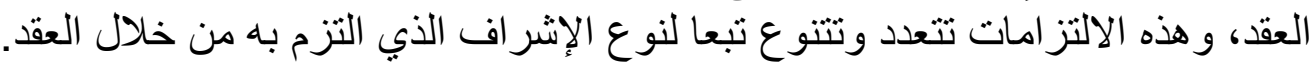

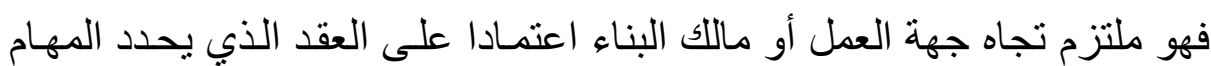

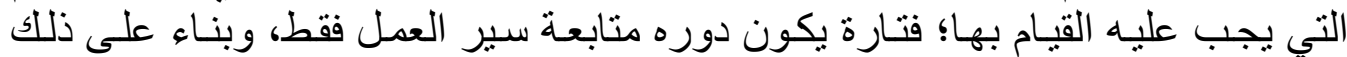

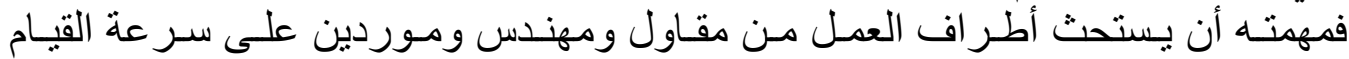

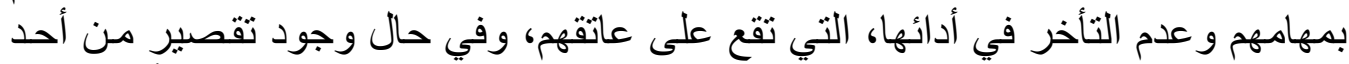

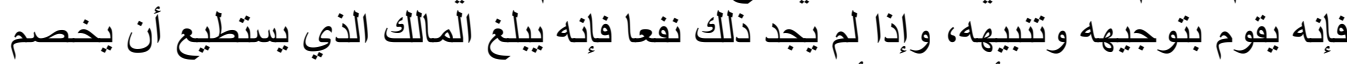

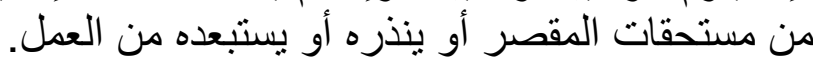

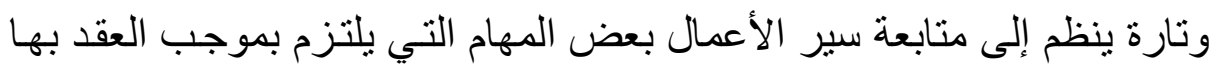

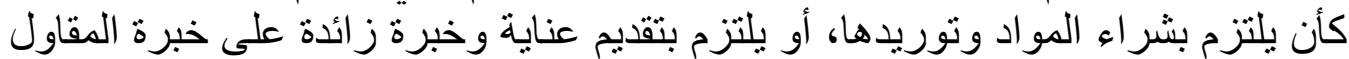

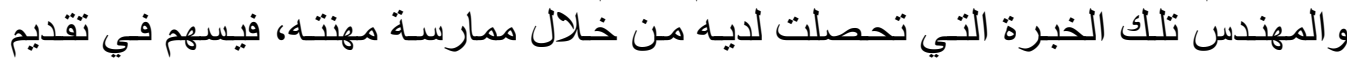

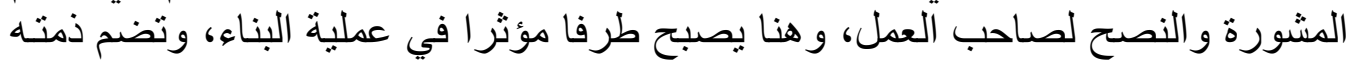

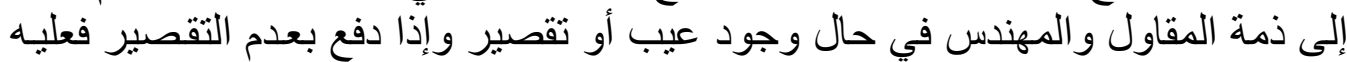

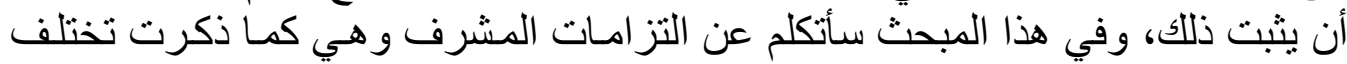
باختلاف العقد الذي يرتب هذب الالتز امات و الحقوق:

\section{المطلب الأول}

\section{التنزامات المشرف في حال اقتنصار دوره على متنابعة سير الأعمال}

في هذه الحالة تترتب عليه مجموعة من الالتزامات بمقتضى العقد ويمكن إجمالها في

1 - يلتزم بمتابعة حضور العمال إلى موقع العمل واستمر ار هم فيه بالشكل الصحيح

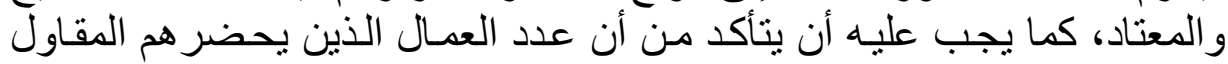
كافٍ في إنجاز العمل في الوقت المبان المتفق عليه في العقد.

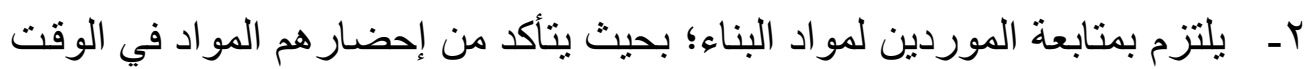

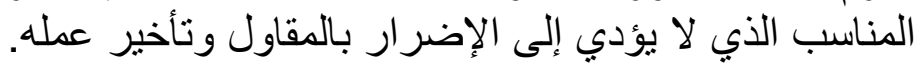

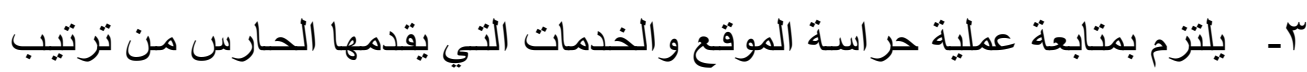
للموقع ورش للخرسانة و البناء و عدم مغادرته لـانه للموقع.

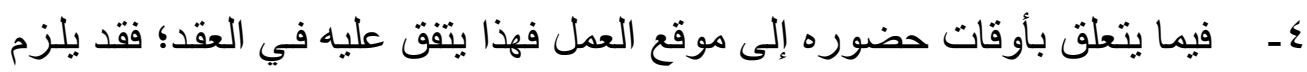

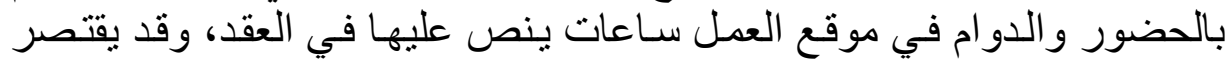


الأمر على حضوره عند الحاجة وهذا هو الشائع والمعمول بـه في أكثر صور الإشر اف.

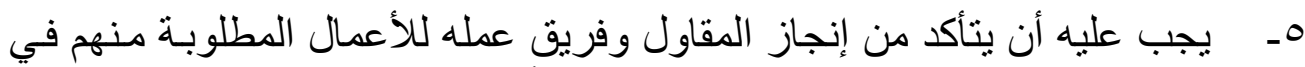

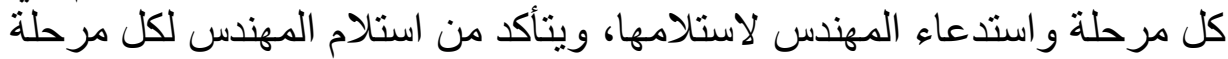
بحسب ما ينص عليه عقد الاستشنارة الهندسية.

7- يلتزم بمتابعة وصول الخدمات إلى الموقع بالثكل الصحيح و المناسب.

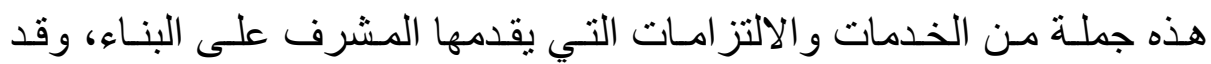

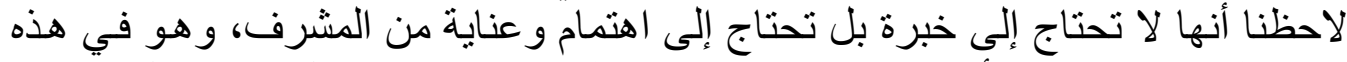

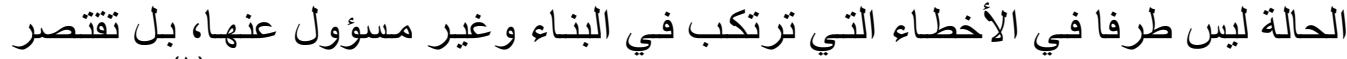

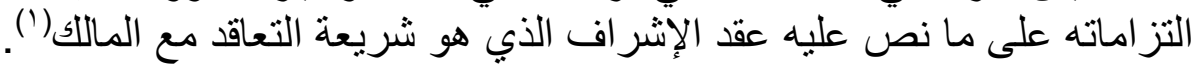

\section{المطلب الثناني}

\section{التزام المشُرف بـتوريب المواد اللازمة للبـناء}

وفي هذه الصورة تزداد التزاماته، ويصبح مسئو لا عن المواد التي التي يوردهـا

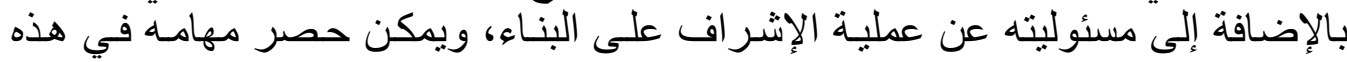

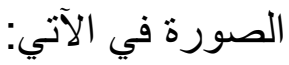

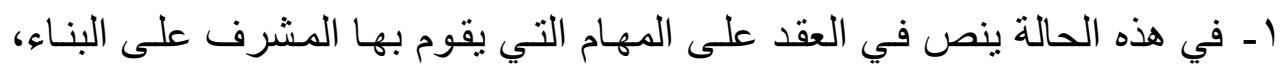

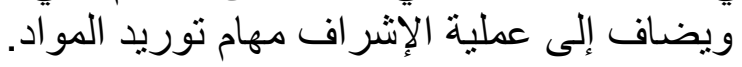

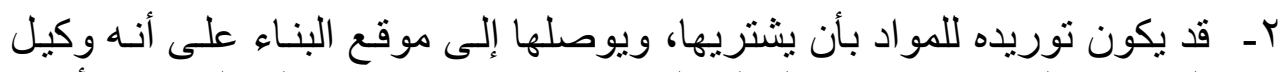

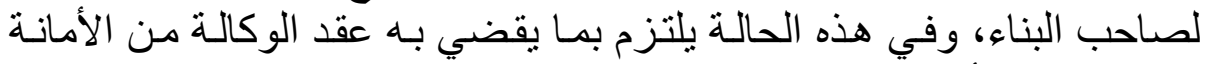

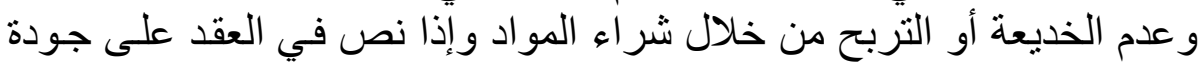

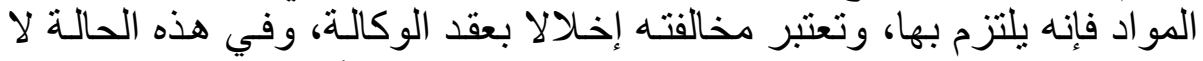

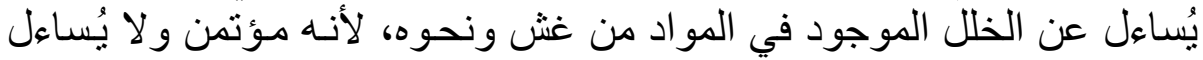
إلا في حال التفريط.

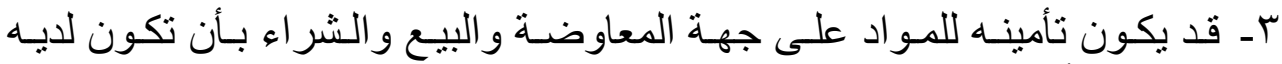

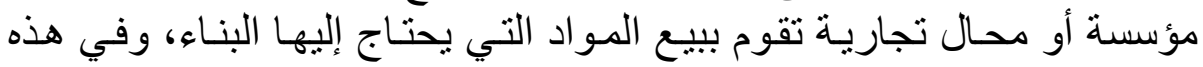

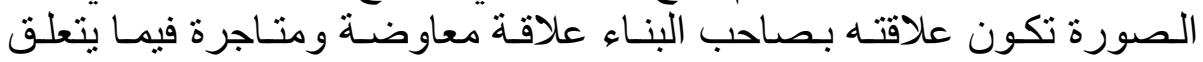

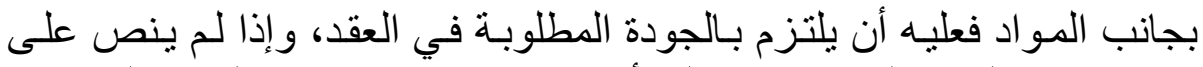

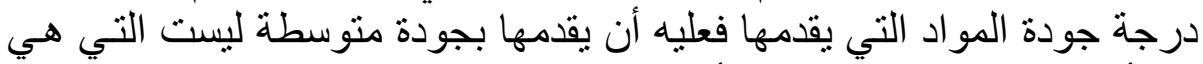

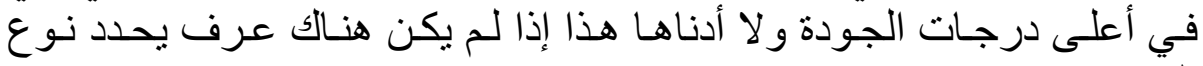
المو اد وجودتها. 


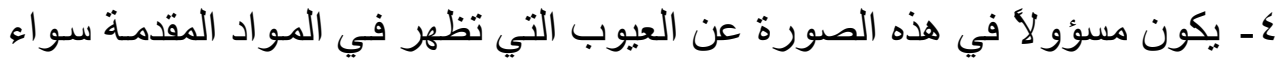

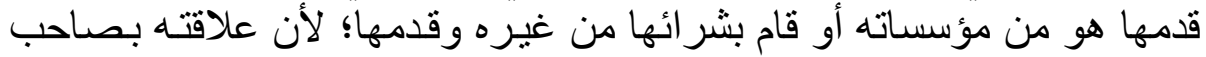

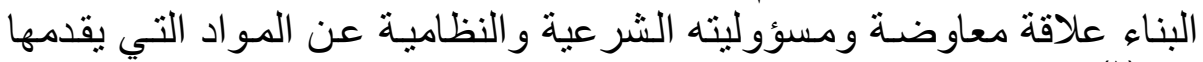

تامة (')

\section{المطلب الثالث}

\section{التزام المشرف بتنقديم المشورة للمالك}

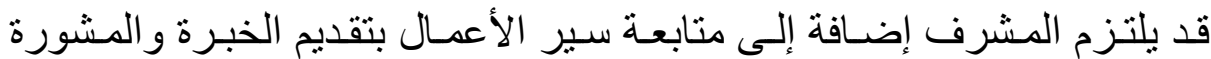

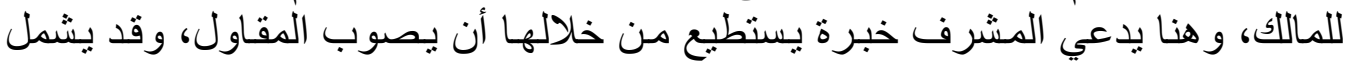

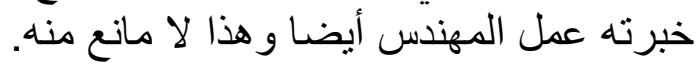

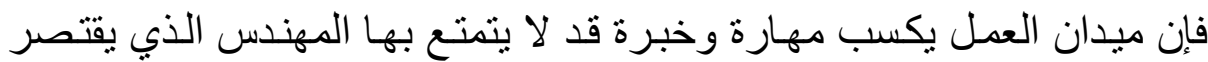

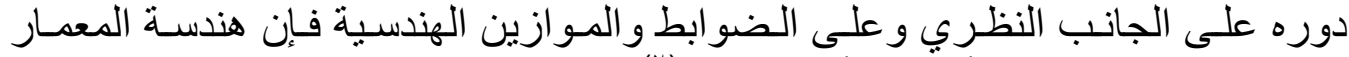
تتحصل للممارس بشكل أفضل وانبل وأكثر و اقعية(؟).

وفي هذه الصورة فإن التزامات المشرف تتشعب، وبنـاء عليها تزداد مسؤوليته

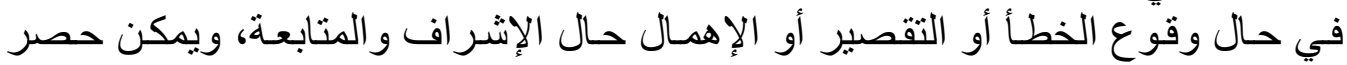

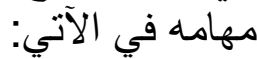

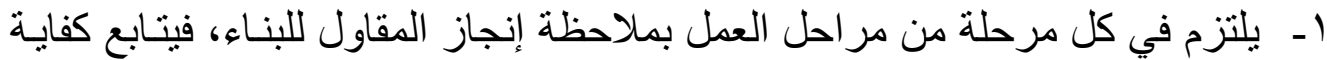

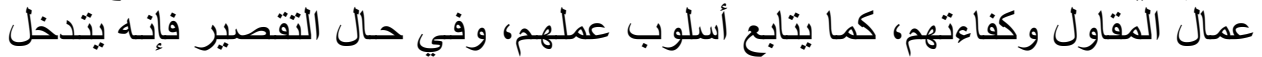

$$
\text { لإصلاح الخلل بموجب الخبرة التي يتمتع بهاء }
$$

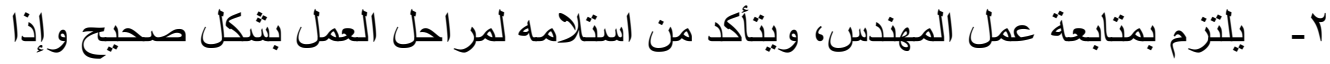

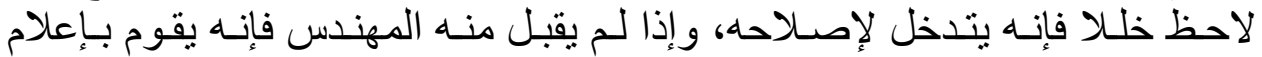

صاحب العمل كي ترتفع عنه المسؤولية.

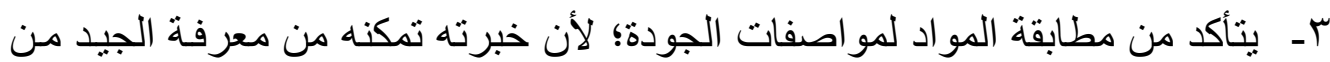

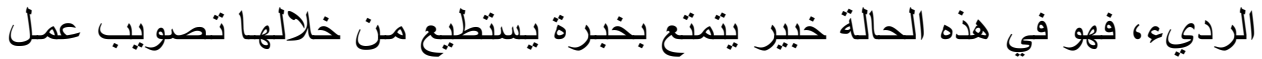

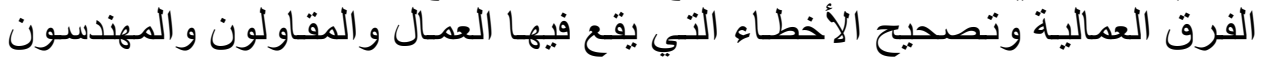

$$
\text { على حد سواء. }
$$

ع - يلتزم بتقديم المشورة لصاحب العمل فيما يعرض ويقدم الحلول لمشـاكل العمل.

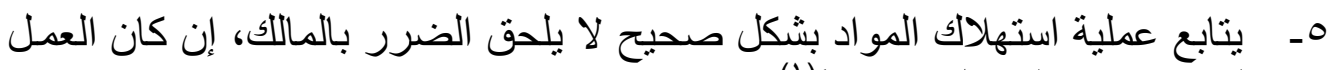

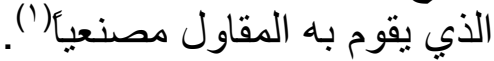

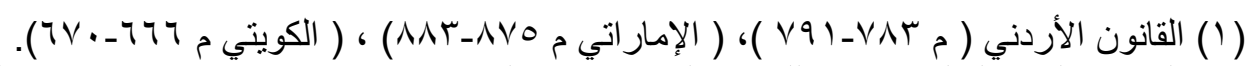

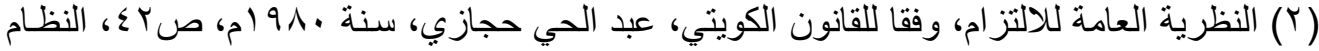

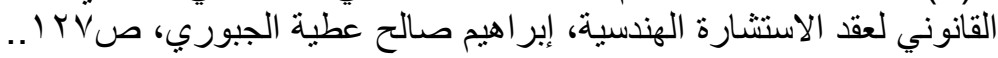




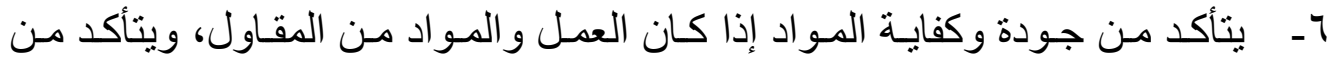

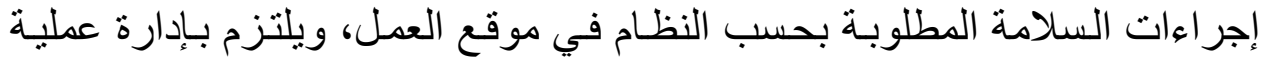

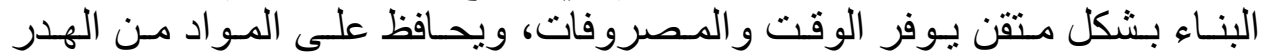

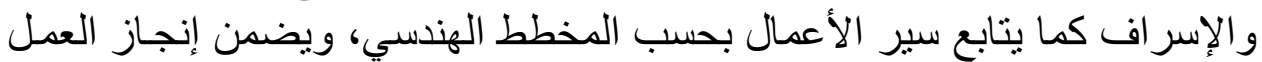

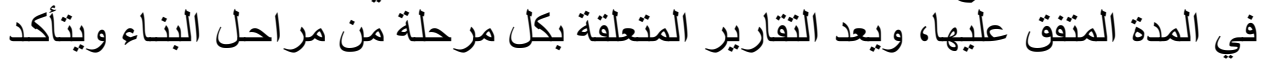

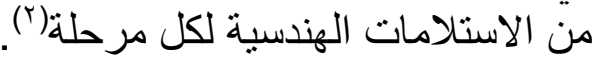

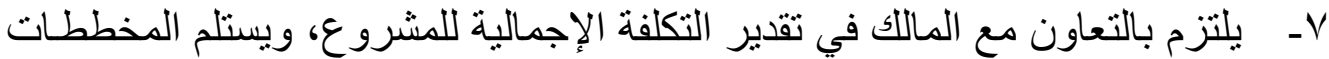

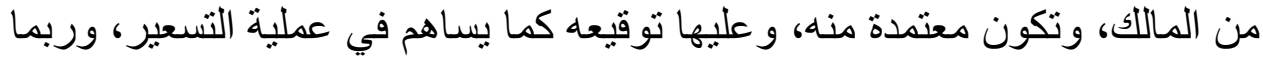

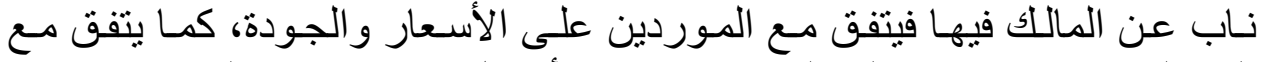

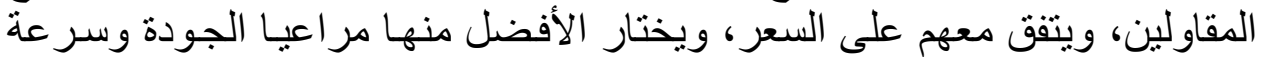

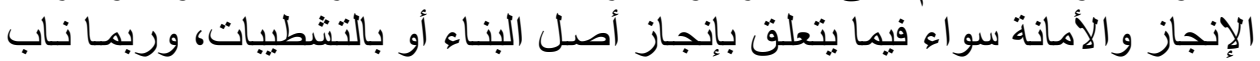

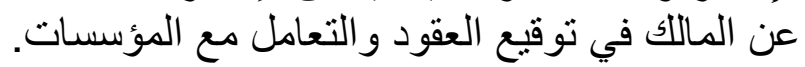

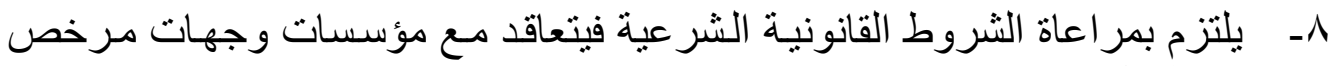
لها بالعمل رسمياً.

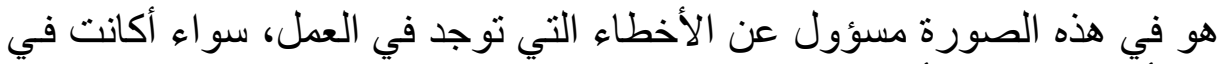

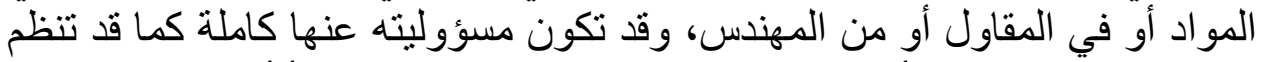

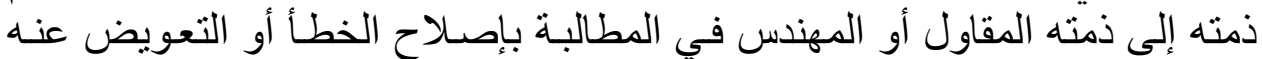

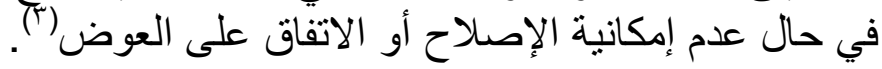

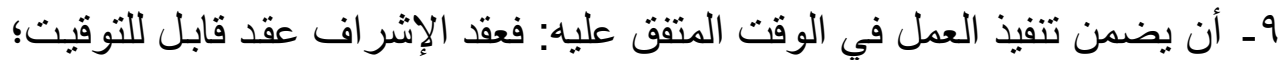

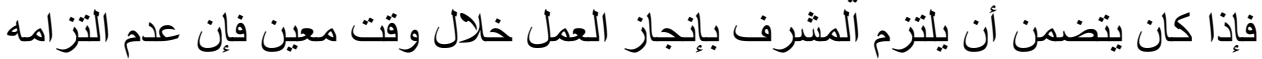

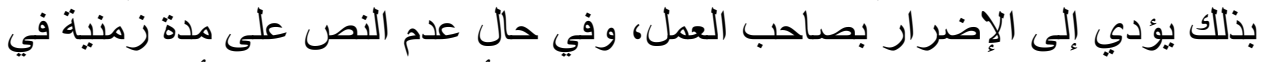

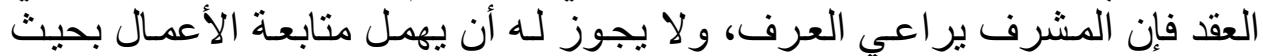

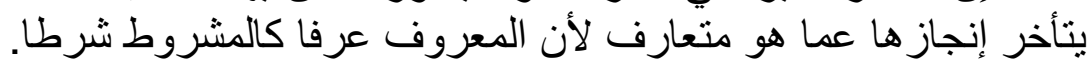

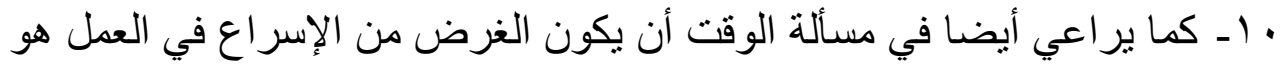

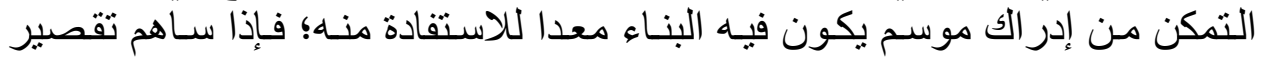

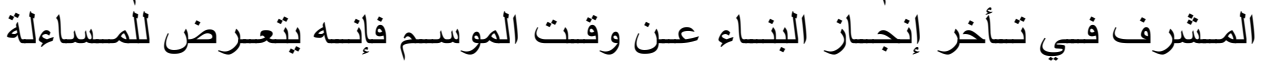

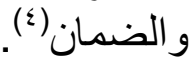

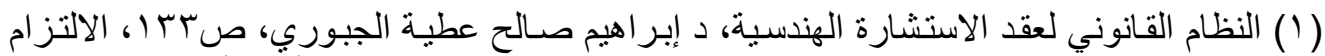

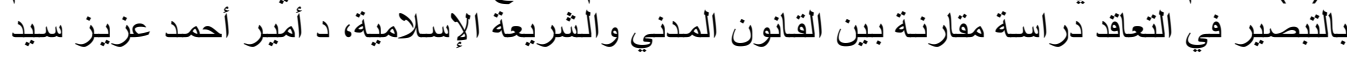

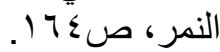

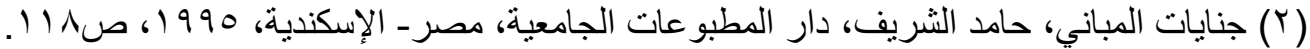

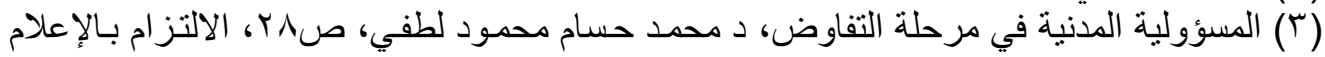

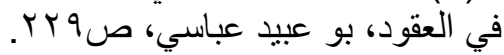

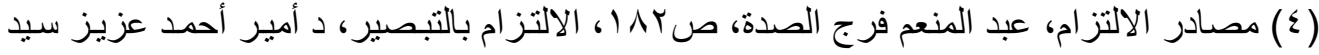

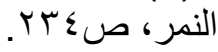


11 - الالتز ام بتنفيذ الأعمال وفق المواصفات المنصوص عليها في العقد:

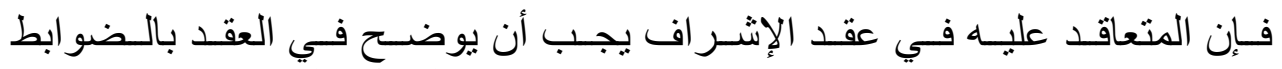

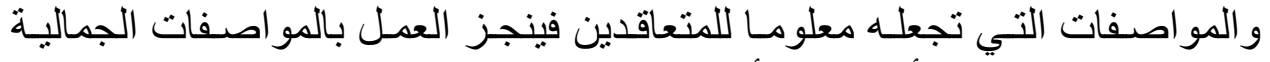

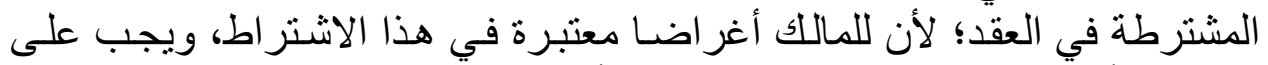

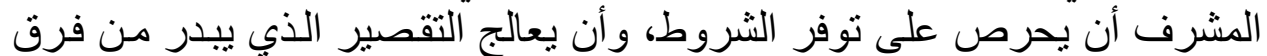

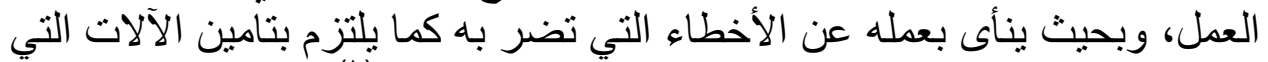

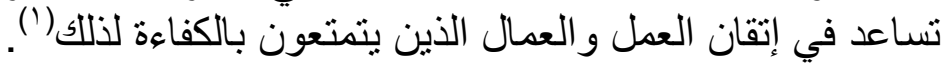

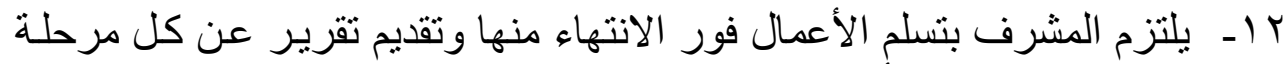

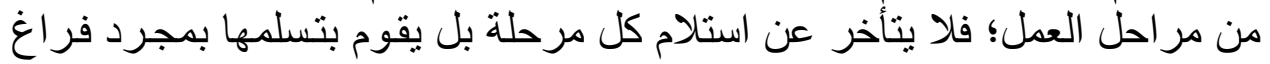

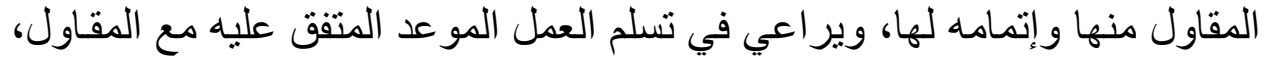

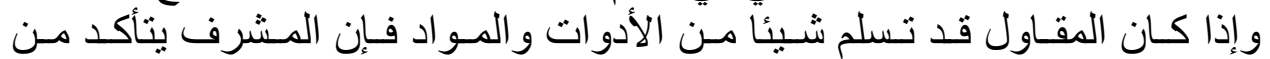

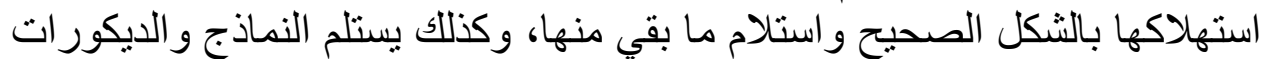

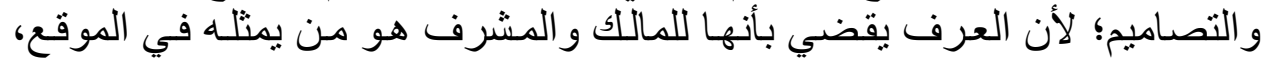

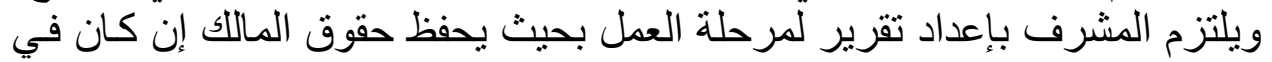
العمل قصور ويؤدي حقوق المقاول و المهندس ومن تحت بـت يدهم من العمال.

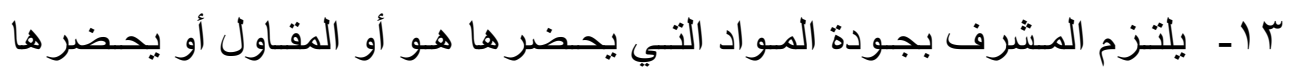

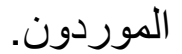

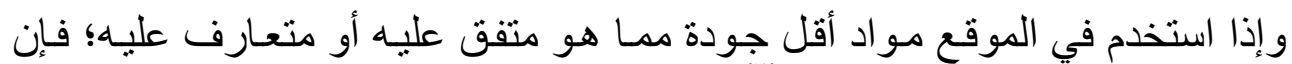

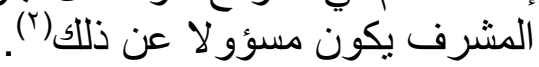

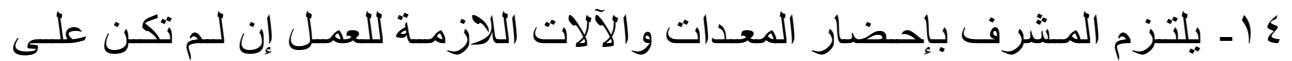

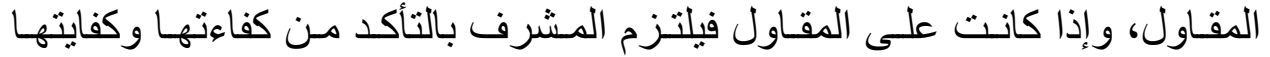

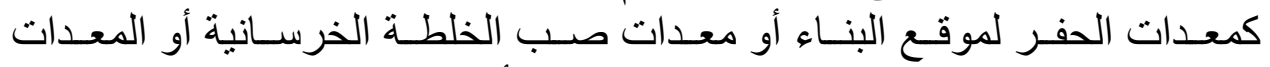

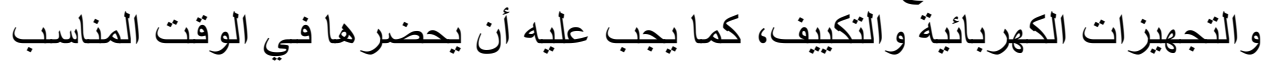
حتى لا يؤدي إلى تأخر العمل بتأخر والتيف كضور ها.

0 ا ـ يلتزم المشرف بالمحافظة على المو اد والآلات بحيث يجنبها ما يفسدها، ويحافظ

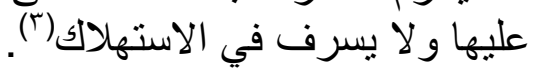

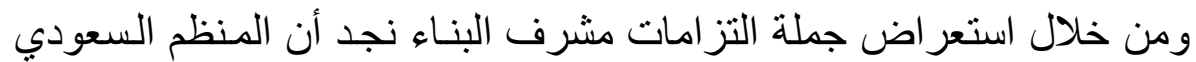

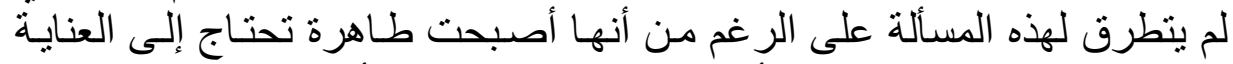
و التنظيم، وفق معايير تحفظ للأطر اف حقوقهم وتلزمهم بأداء ما يجب علئ عليهم.

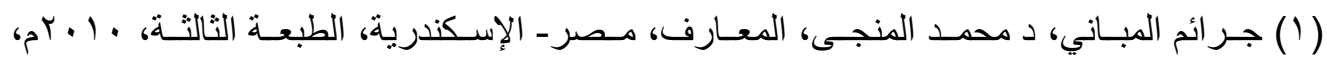

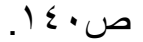

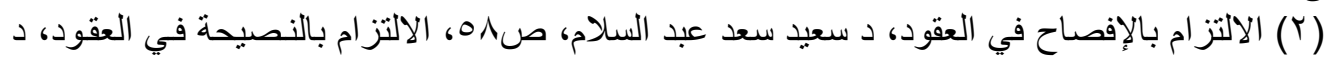

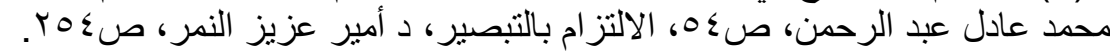

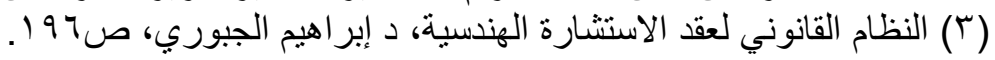




\section{المطll}

\section{التززامات المالك تتجاه المشُرف}

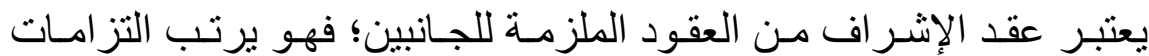

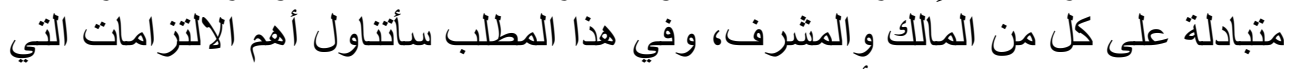
تقع على عاتق المالك ومن أبرز ها:

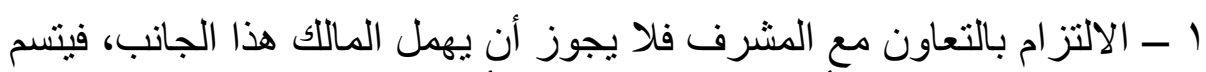

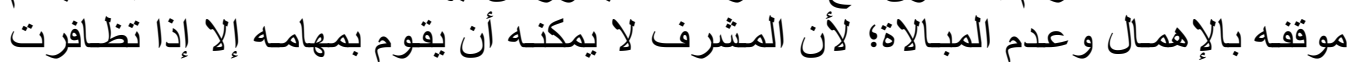

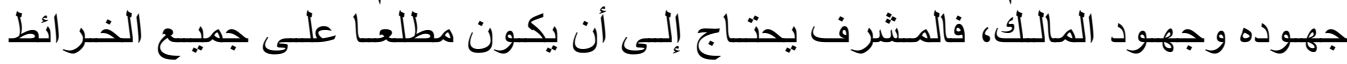

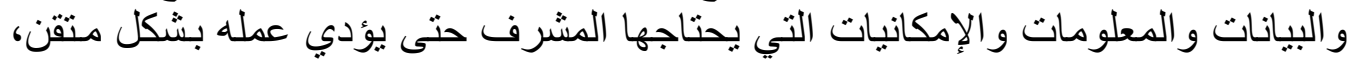

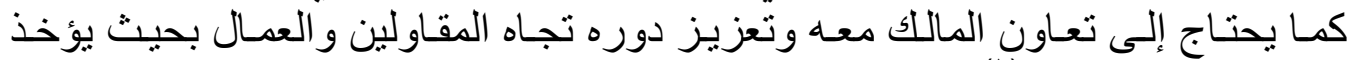
توجيهه بعين الاعتبار (')

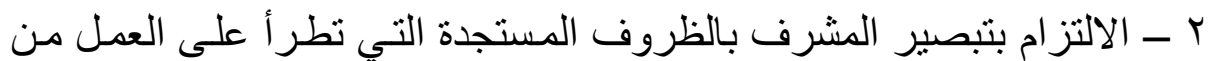

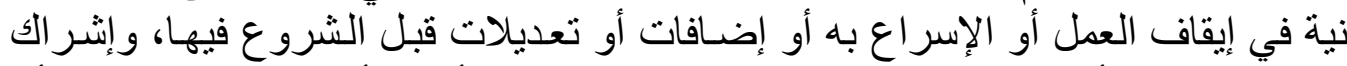

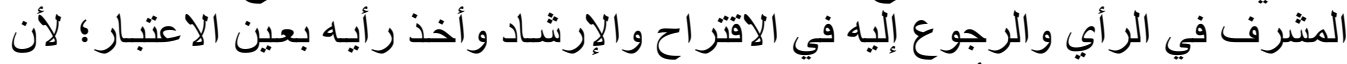

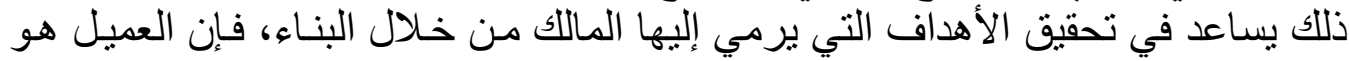

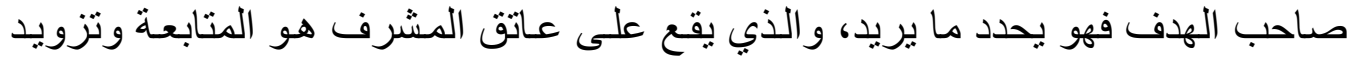

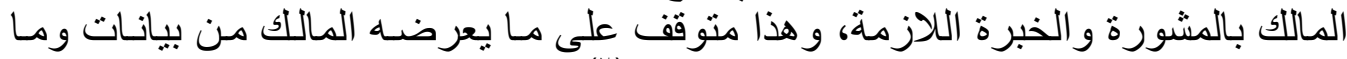

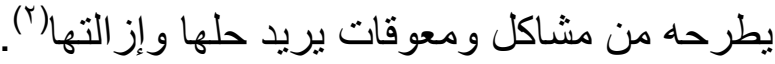

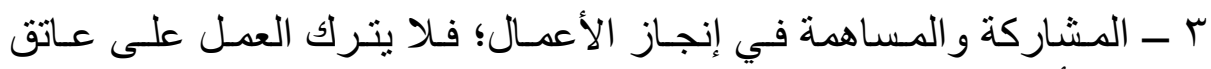

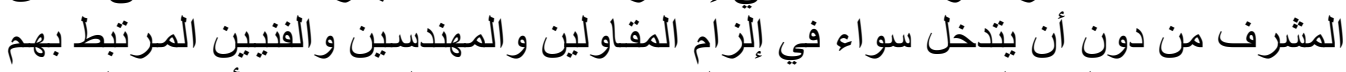

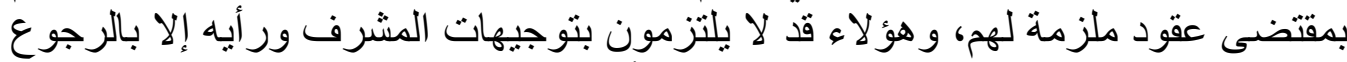

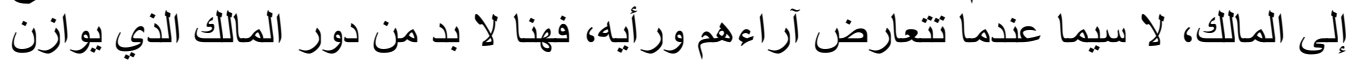

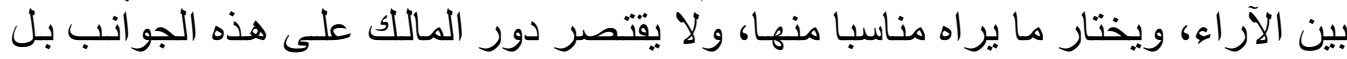

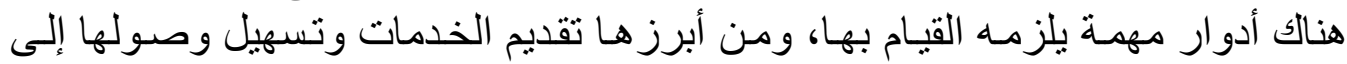

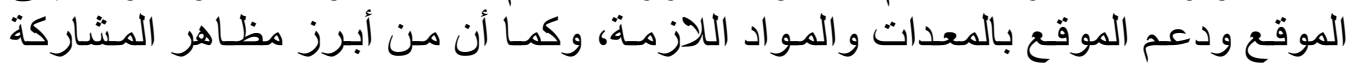

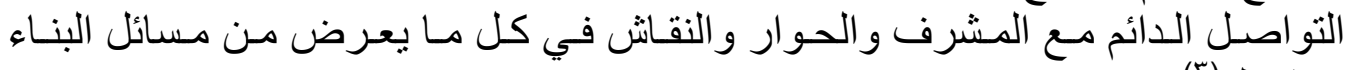

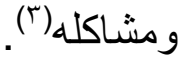

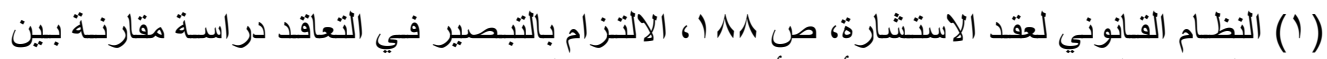

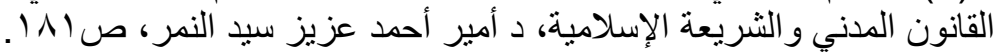

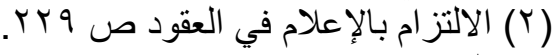

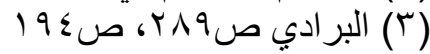




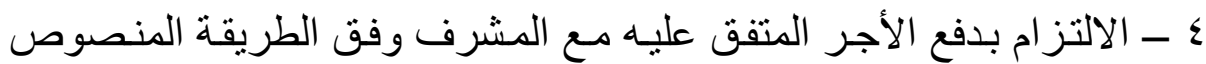

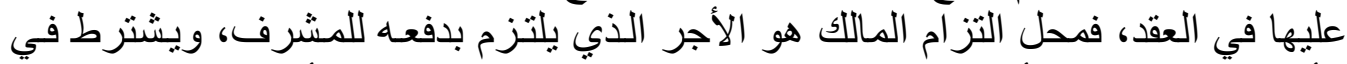

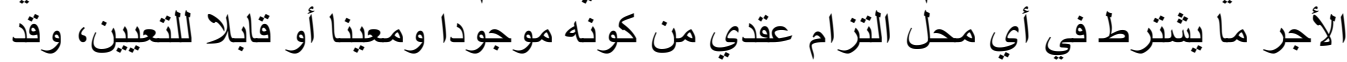

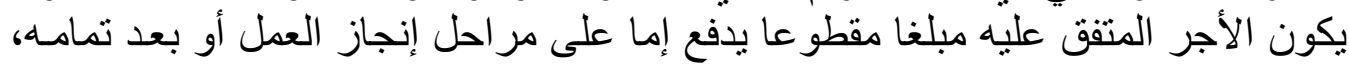

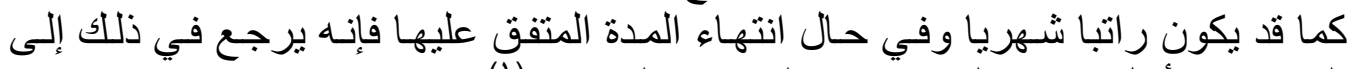

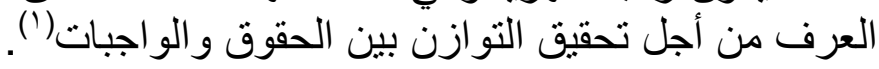




\section{المبحث الثالث}

\section{هدى ضهان هشرف البناء لأفعاله وتصرفاته الضارة مدعما}

\section{المطلب الأول}

\section{أركاز المسؤولية لطرفي عقد الإشراف على المبانيي}

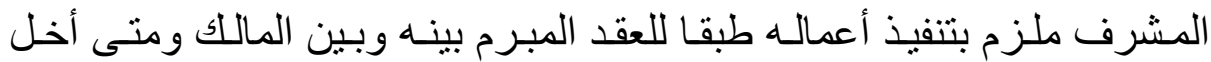

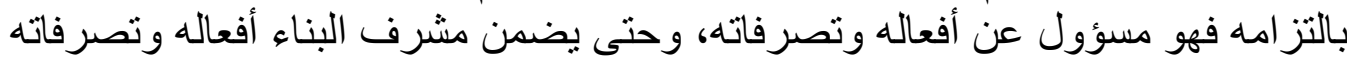

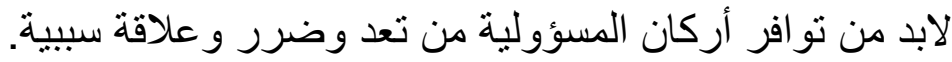
تعريف الضمان:

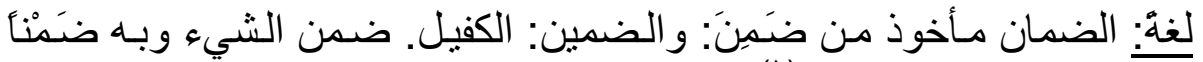

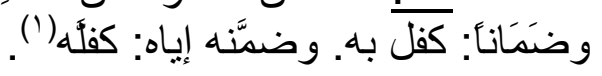

اصطلاحا: ضم ذمة إلى ذمة في المطالبة(؟)، وهي مشتقة من الكفل وهو الضم

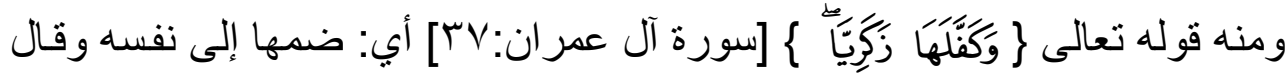

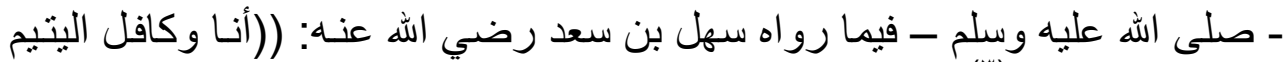

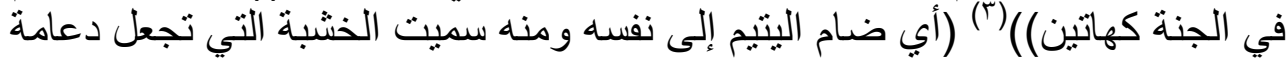

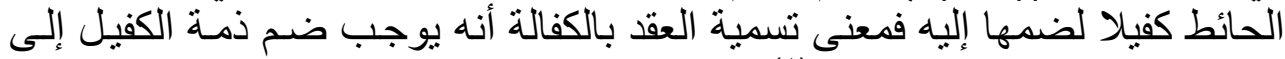

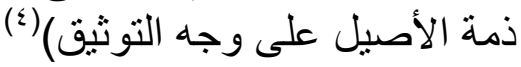

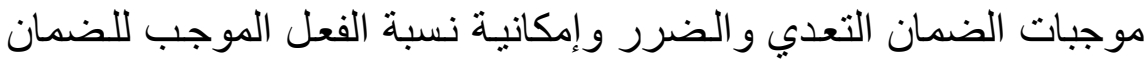

إلى من بر اد تضمينه وهذا الموجب يشمل الفعل سواء كان مباشرة أو تسببئ(ه).

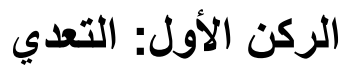

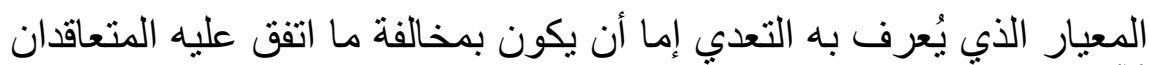

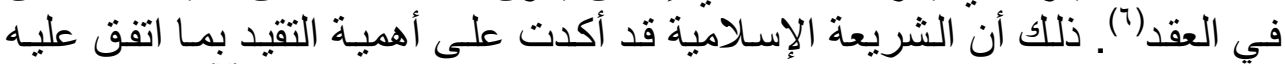

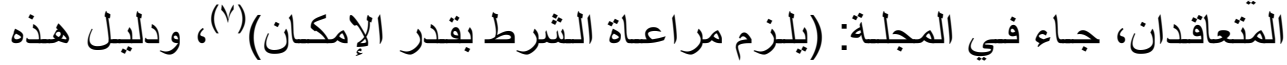

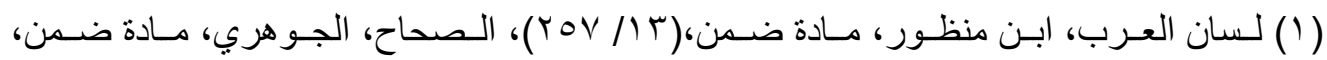

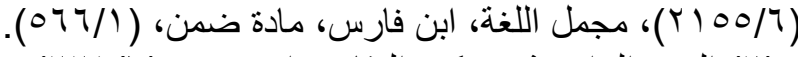

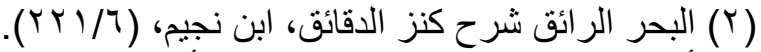

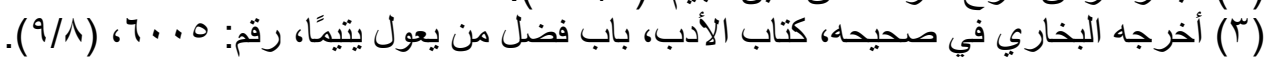

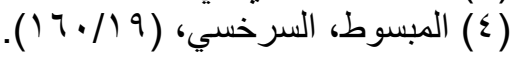

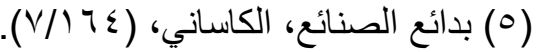

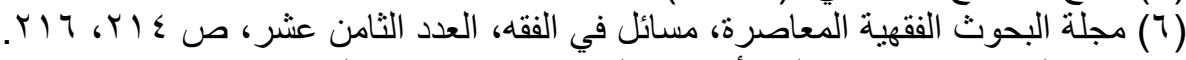

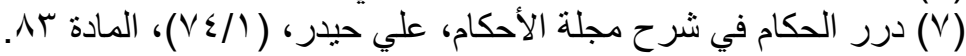




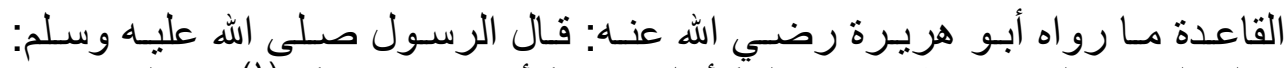

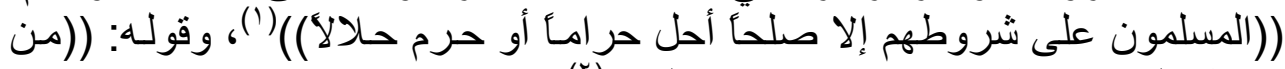

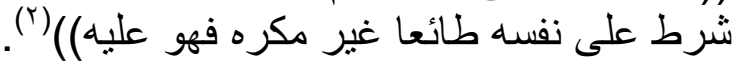

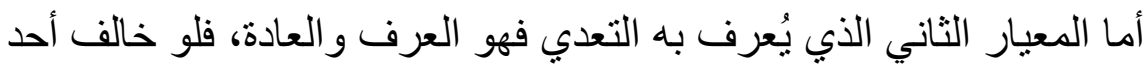

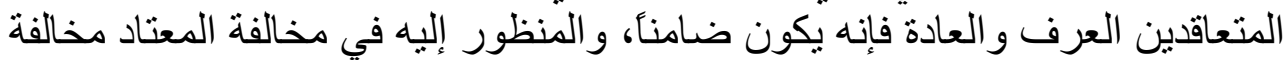

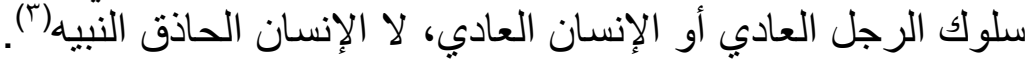

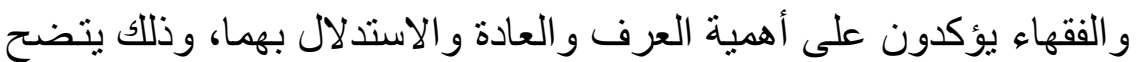

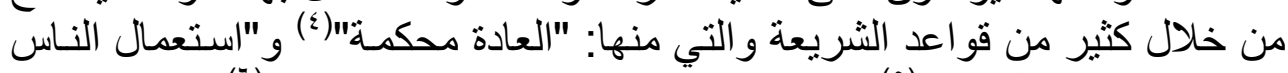

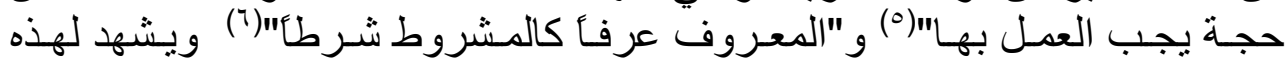

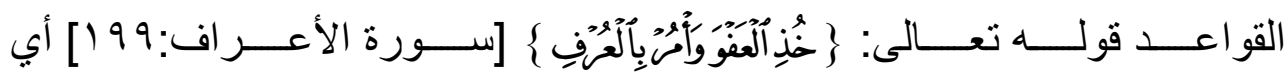

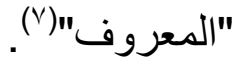

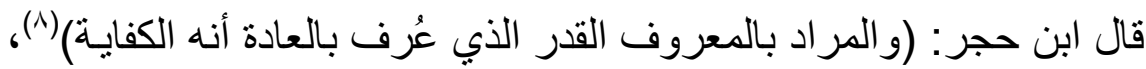

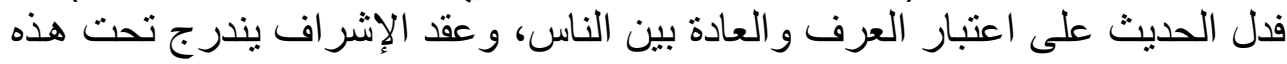
المعايير.

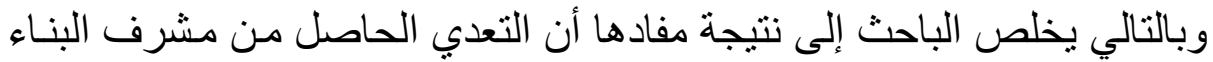

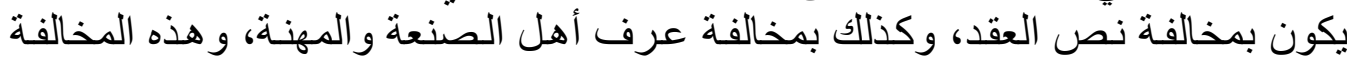

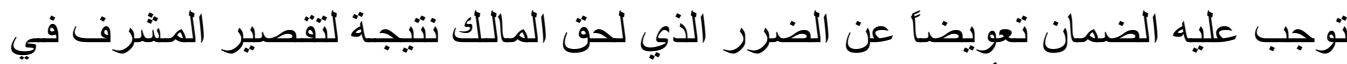

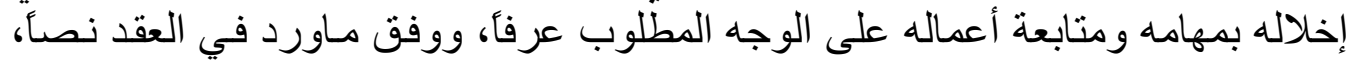

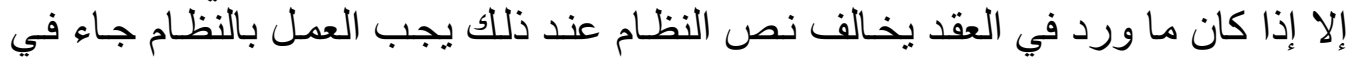

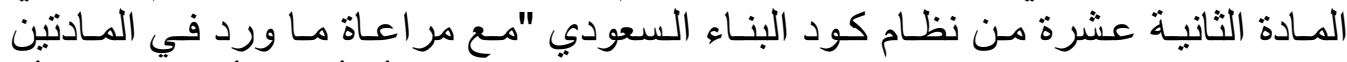

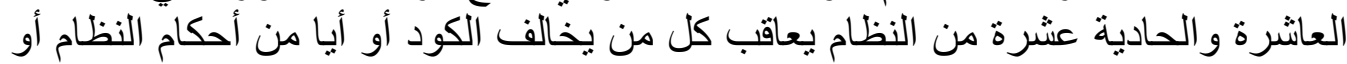

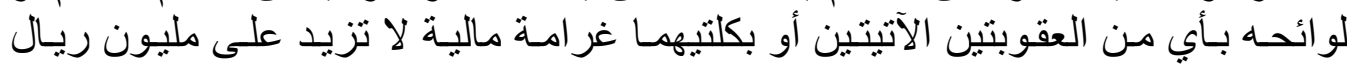

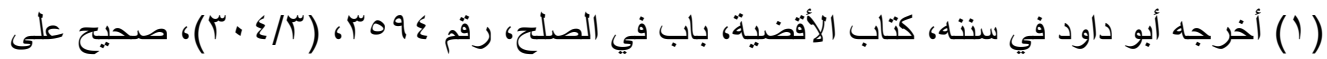

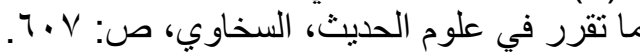

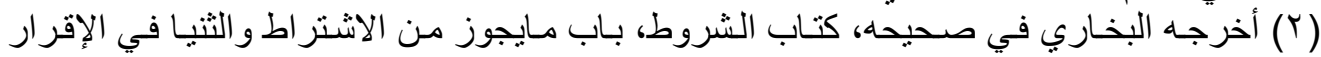

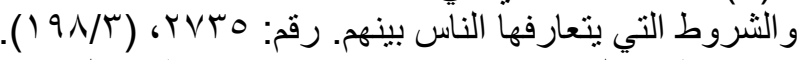

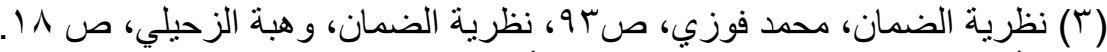

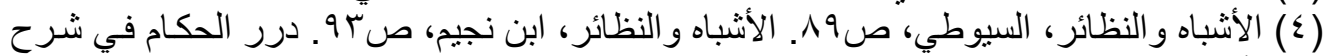

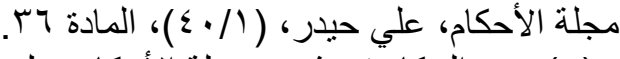

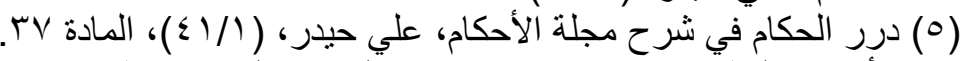

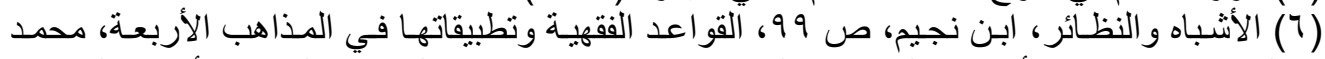

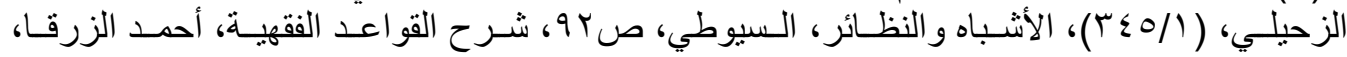

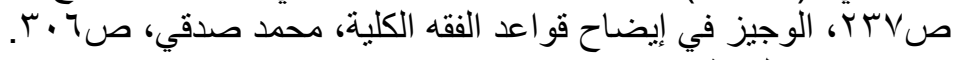

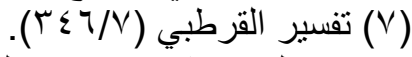

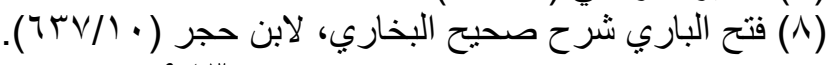


للمخالفة الواحدة في المبنى الواحد. ثانيا: إيقاف رخصة الممارسة مدة لا تقل عن شـهر، و لا تتجاوز سنة واحدة".

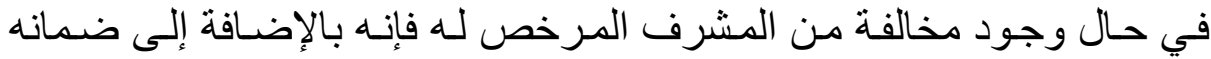

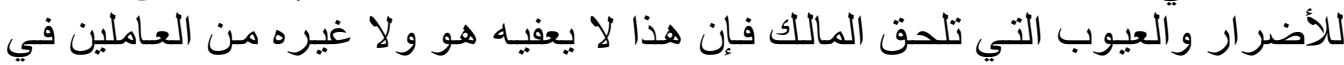

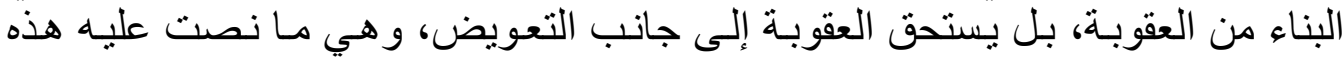

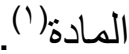

\section{الركن الثاني: الضرر}

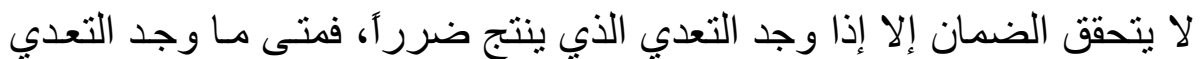

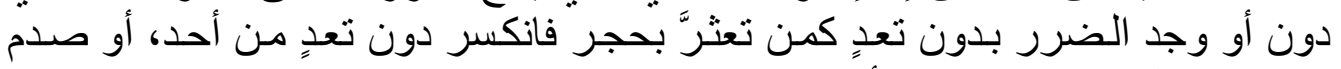

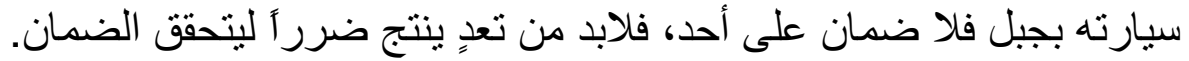
تعريف الضرر:

لغة: خلاف النفع(r).

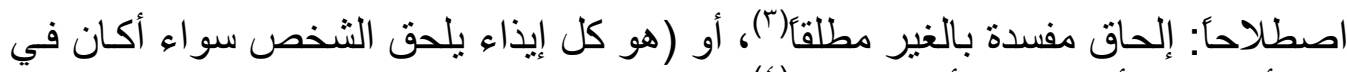

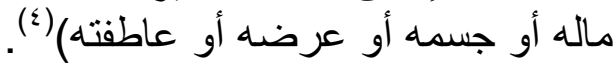
و التعريف المختار للباحث هو: هو الاعتداء على الغير مطلقأ.

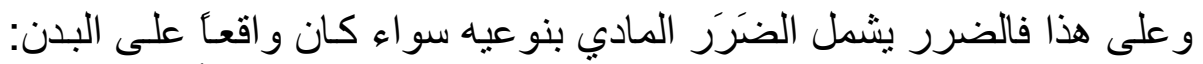

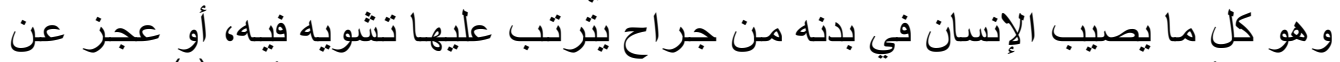

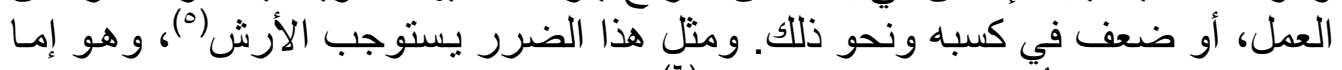

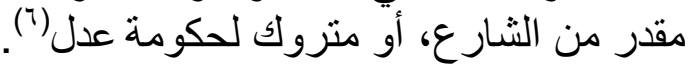

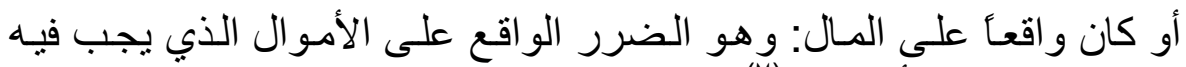

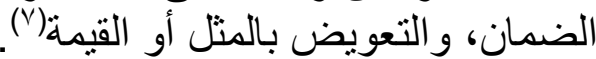

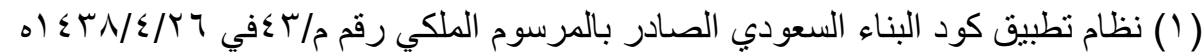

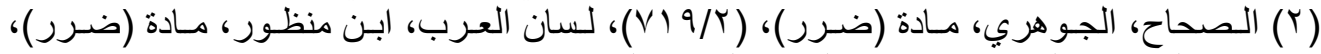

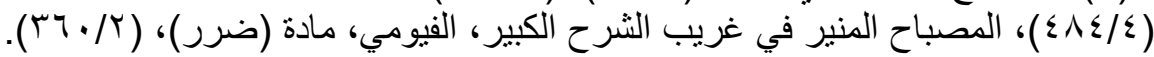

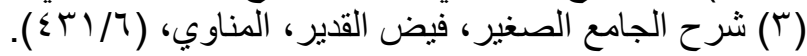

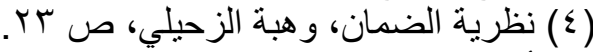

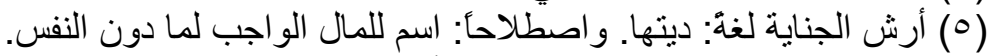

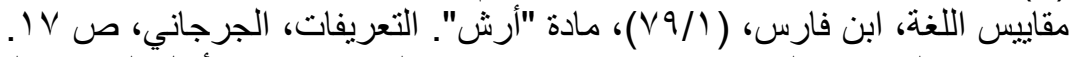

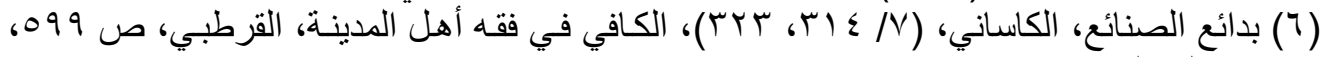

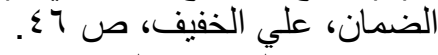

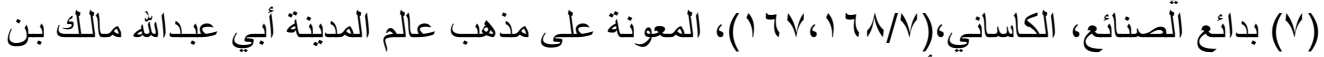

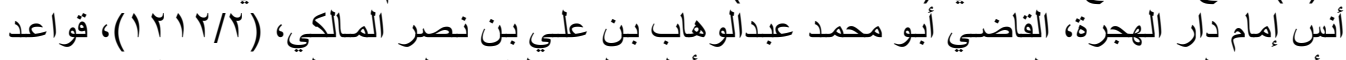

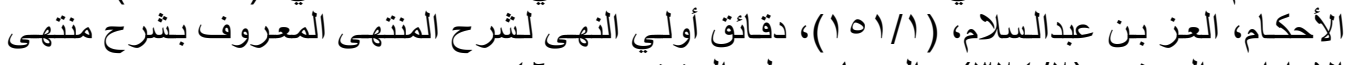

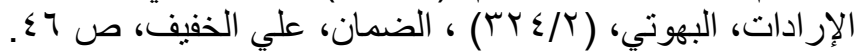




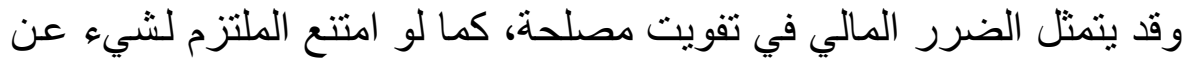

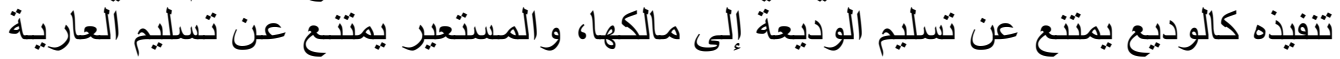

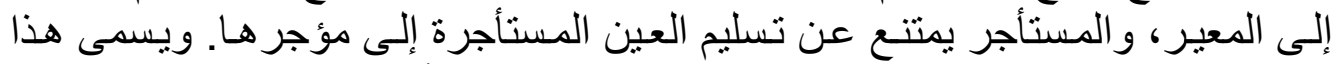

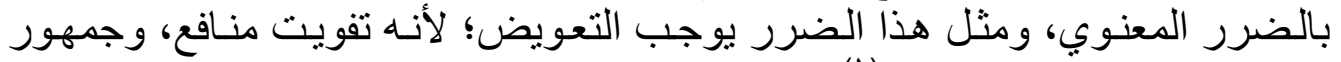

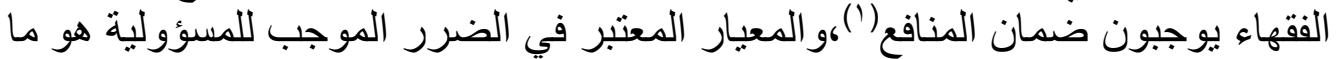

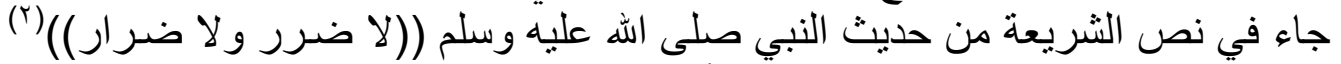

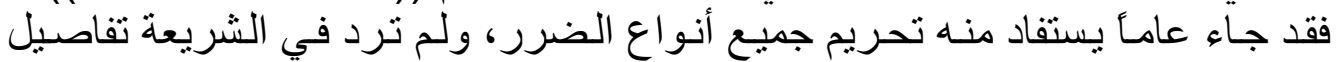

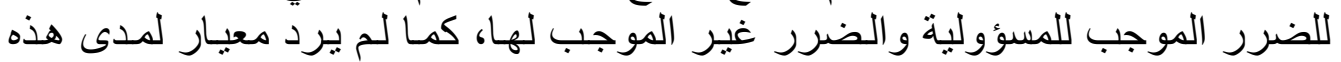

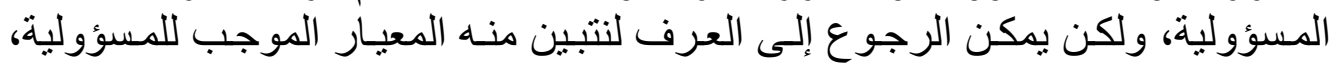

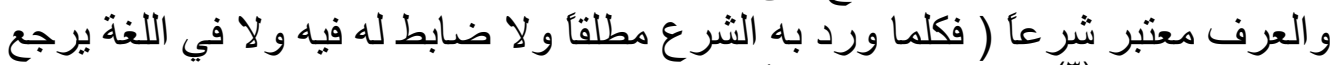

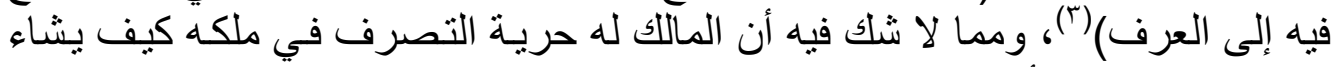

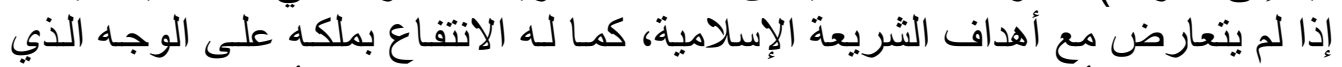

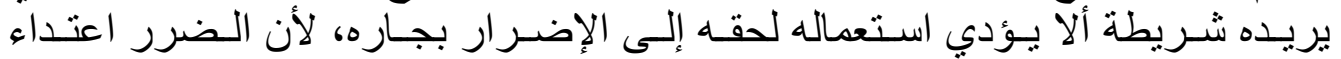

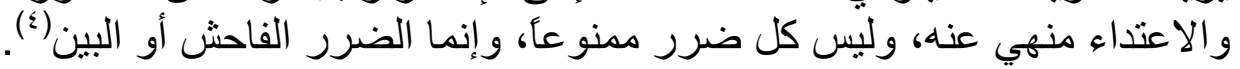

الركن الثالث: الإفضاء

تعريف الإفضاء:

لغةٌ: من أفضى يفضي إفضاء، أفضى أي صار في فضاء ولم يتحرز بشيء،

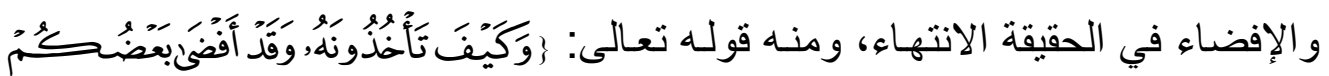

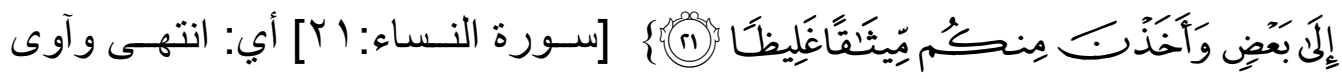

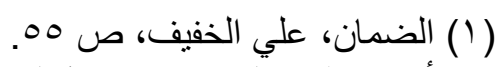

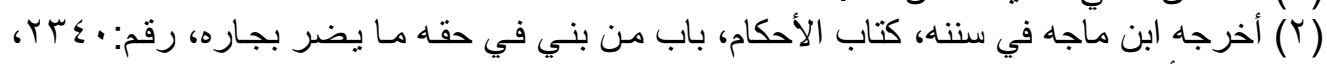

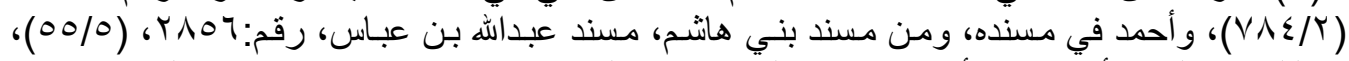

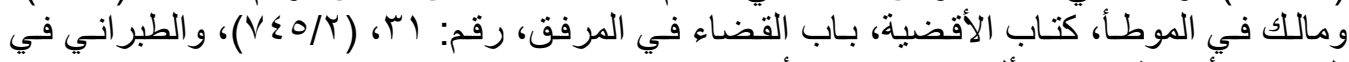

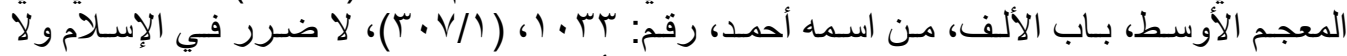

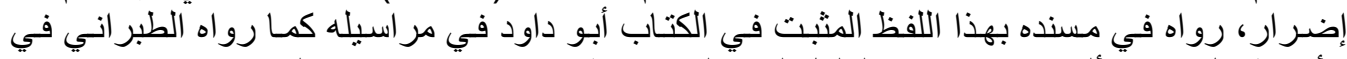

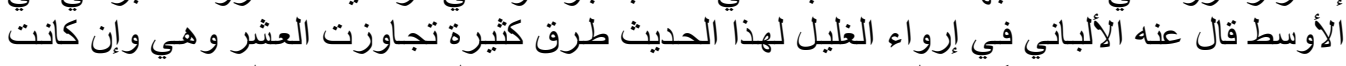

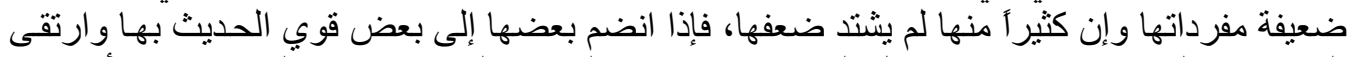

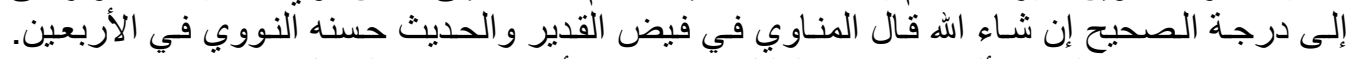

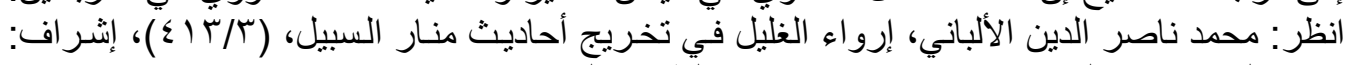

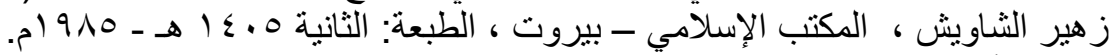

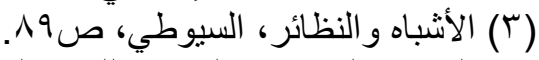
( ) التكييف الثر عي و القانوني للمسؤولية المدنية الناشئة عن مضار الجوار ، مر اد حيدر ، ص ع ؟ب. 


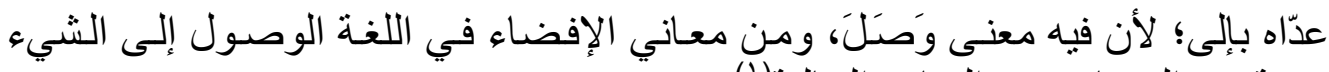

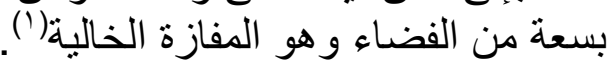

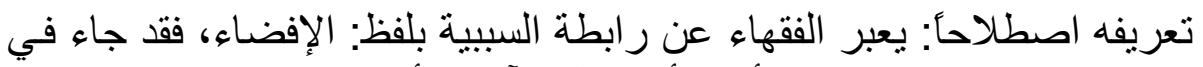

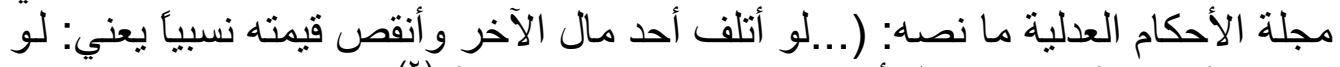

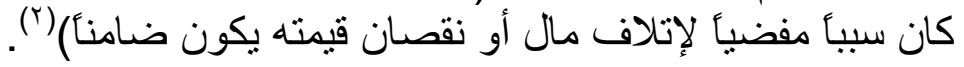

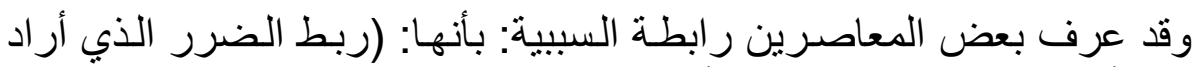

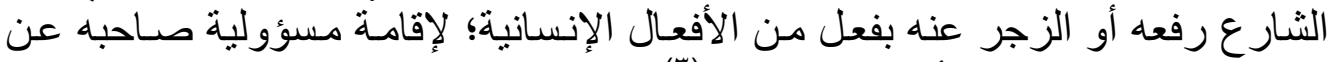
الضرر، وإيجاب ضمانه أو العقوبة عليه)(").

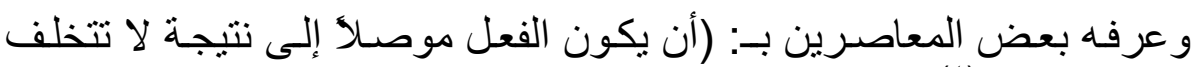

عنه، إذا انتفت الموانع)(

ويمكن تعريفه بـ ( أن يترتب على الفعل نتيجة لازمـة لله مـع توفر الشروط و انتفاء المو انع).

وقد حدد الفقهاء هذه الصلة أو رابطة السببية بين التعدي والضرر بأنها:

أ- إما أن تكون على سبيل المباثرة.

ب- و إما أن تكون على سبيل السببية.

فلا ضمان في غير المباثرة والتسبب، فيضدن المباشر الضرر دون مـا حاجـة

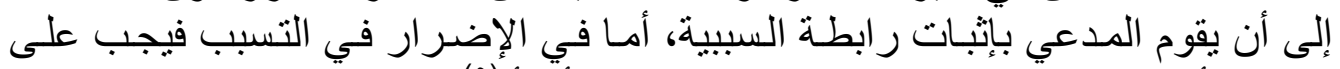

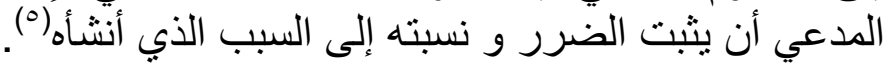

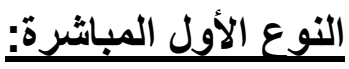

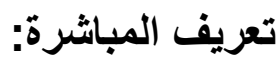

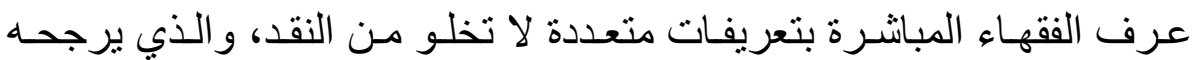

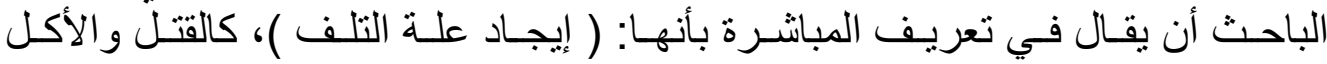

(1) انظر : كتاب العين، الفراهيدي، مادة ( أفضى) (ب/ع §)، لسان العرب، ابن منظور ، مادة (فضا)،

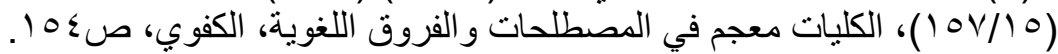

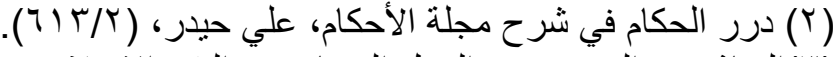

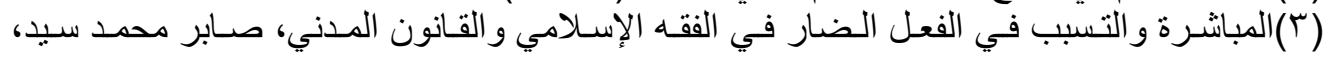
(§) انظر : دفع المسؤولية المدنيـة وتطبيقاتهـا القضائية دراسـة مقارنـة، د.محمد بـن عبيد الجنـاح

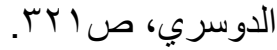

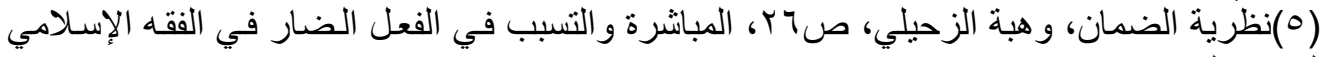

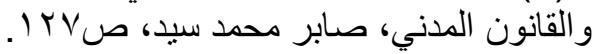


و الإحر اق، وذللك لأن الذي يضاف إليه التلف في العـادة والعرف إضـافة حقيقية، يسمى

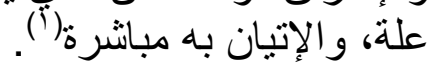

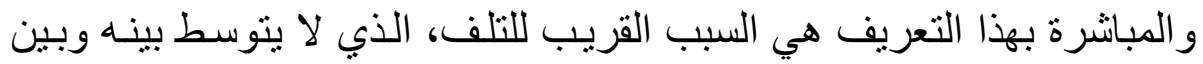

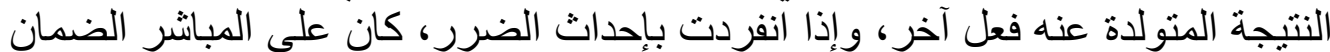

النوع الثانى: السبب تعريف السبب:

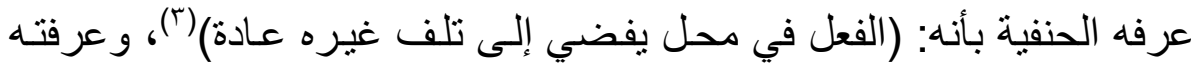
مجلة الأحكام العدلية بأنه: (إحداث أمر في شئ شيء يفضي إلى في تلف شيء آلفي آخر على جري

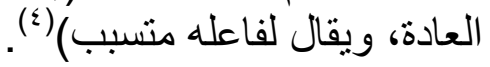

\section{الفرق بين التسبب والمباشرة:}

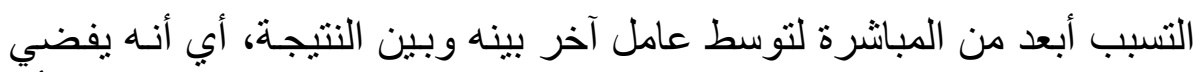

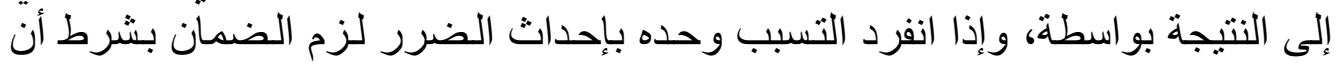

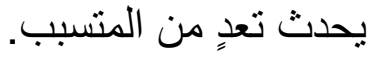

فالإتلاف بالتسبب هو كل فعل يفضي عادة إلى الإتلاف دون أن يتخل إنلل بينهما

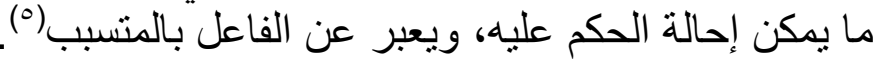
معيار رابطة السببية: - مالية

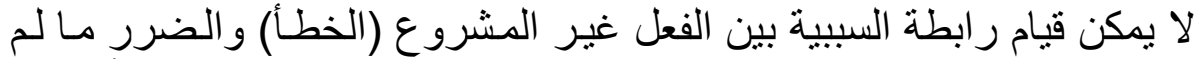

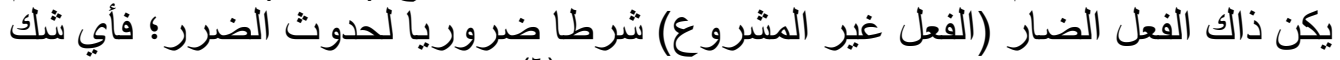

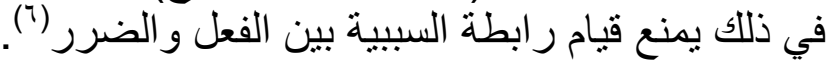

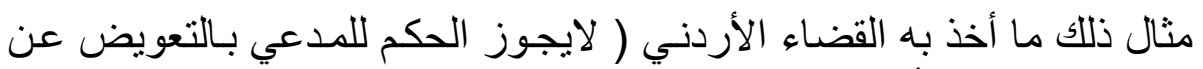
إصابته بالقلق النفسي دون أن تبين المحكمة وجود الفياه الردة ابطة السببية بين هذا القلق وحادث

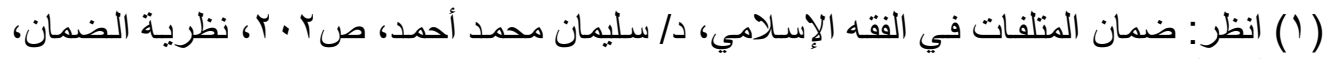

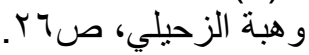
(Y) انظر: ضئمان العدوان في الفقه الإسلامي دراسـة فقهية مقارنة بأحكام المسؤولية التقصيرية في

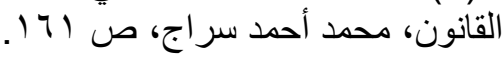

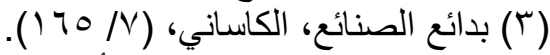

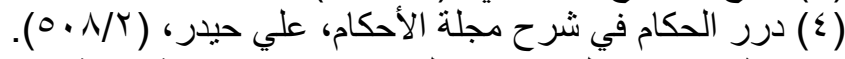

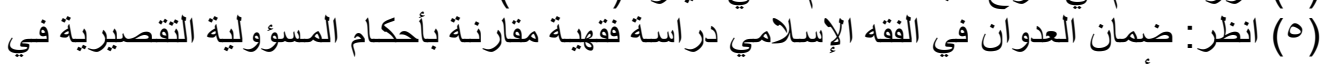

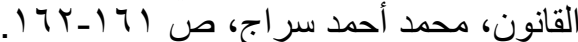

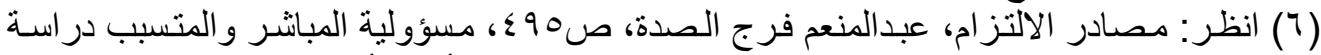

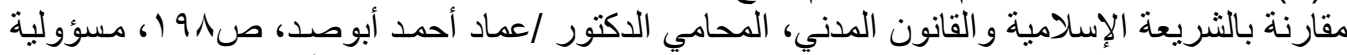

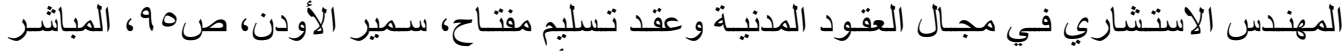

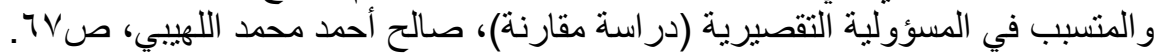


سقوط المدعي في الحفرة؛ لأن وجود الرابطة السببية أمر ضروري، ولايثبت إلا بالبينة

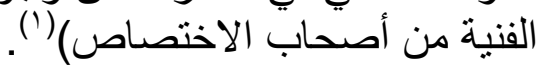

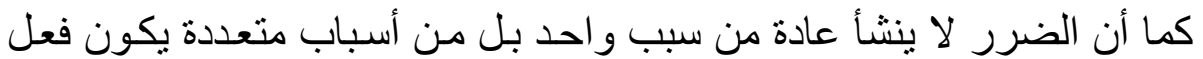

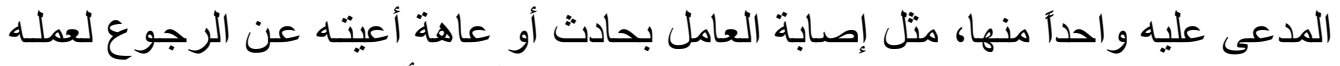

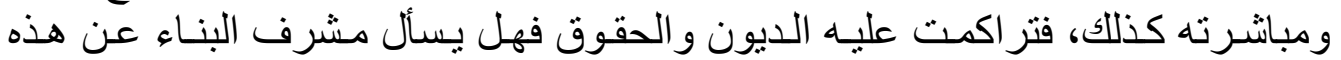

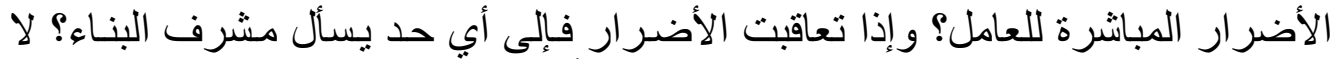

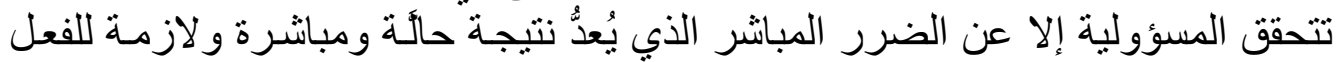

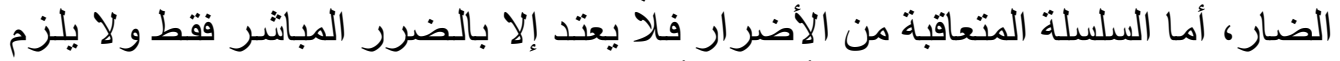

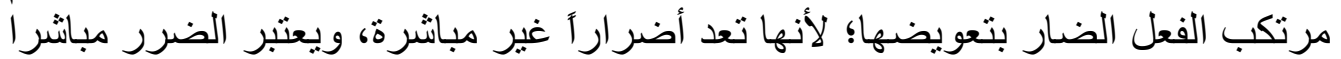

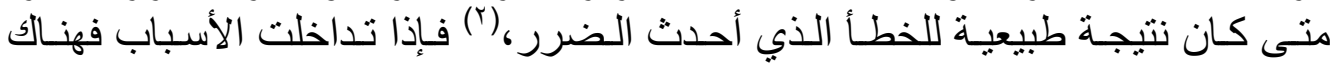

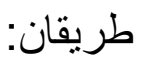

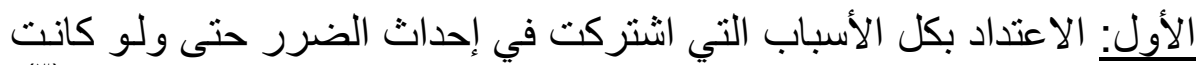

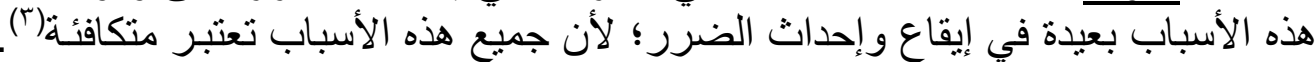

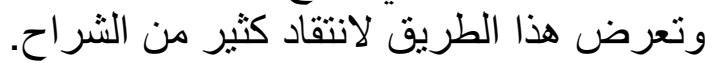

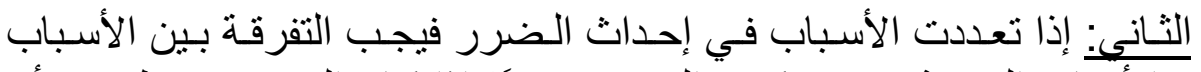

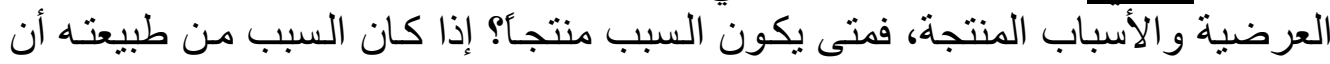

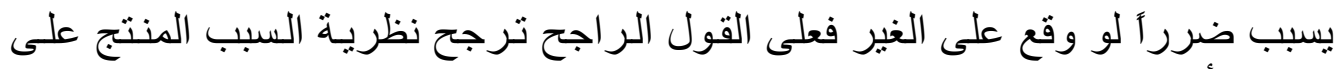

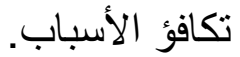

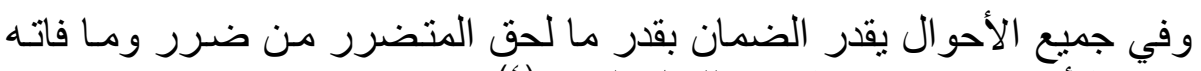

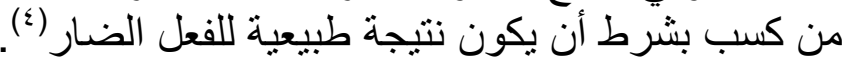

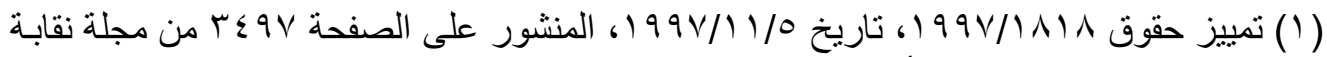

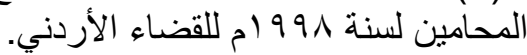

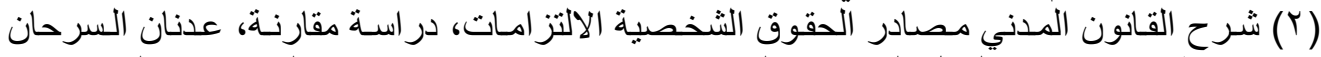

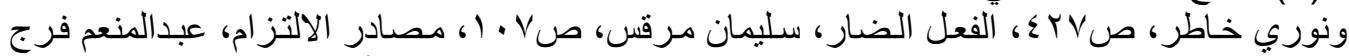

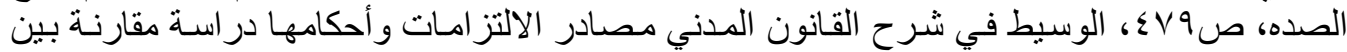

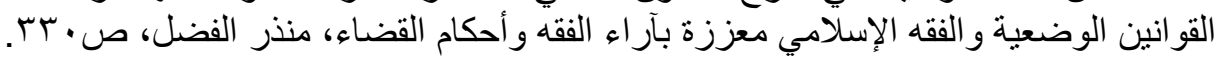

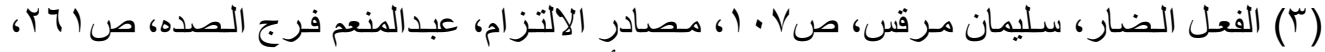

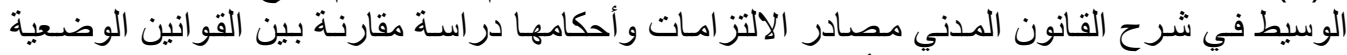

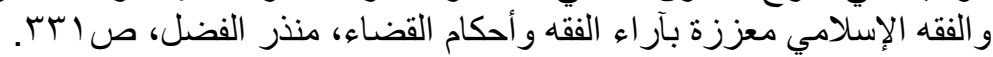

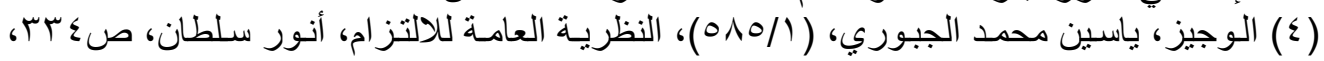

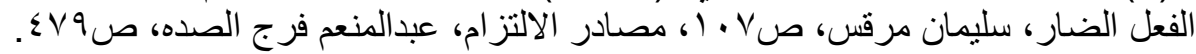




\title{
1المطلب الثناني
}

\section{ضمان الأضرار الناتجة عن تصرفات مشُرف البــاء}

\author{
الفرع الأول
}

ضمان الأضرار الناتجة عن تصرفات مشرف البناء حال انفراده

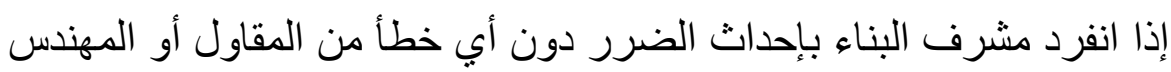

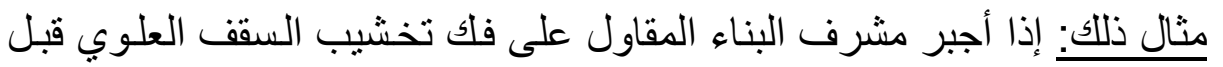

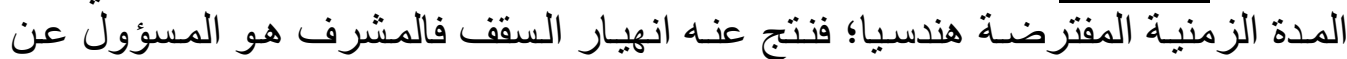
الضرر، ويتحمل التعويض لوحنة لوحده نتيجة فعله و لا شيء على على المقاول.

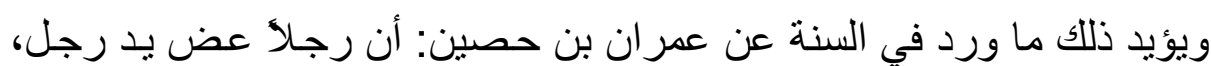

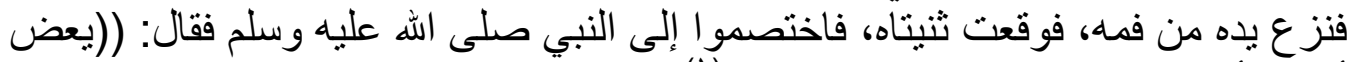

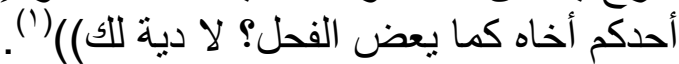

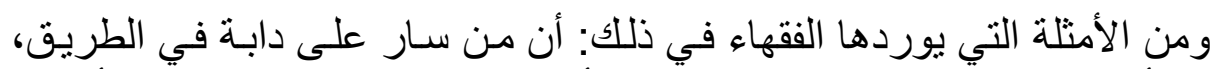

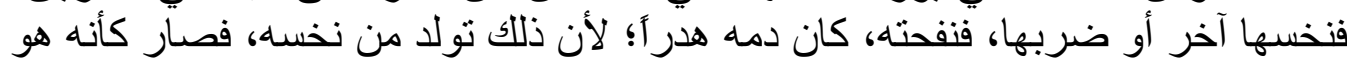
الذي جنى على نفسه(ب).

\section{الفرع الثاني}

ضمان الأضرار الناتجة عن تصرفات مشرف البناء حال اشتراكه مع الفرع

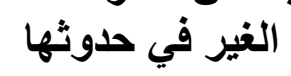

إذا اشترك خطأ المشرف مع فعل الغير فلا يخلو من حالتين:

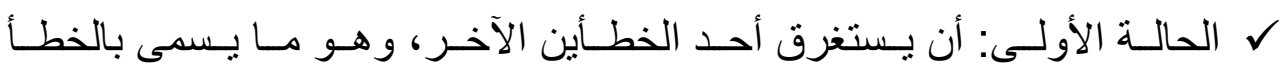
المسُستغرق.

ل الحالة الثانية: أن يشترك كلا الخطائن في إحداث الضرر دون استغراق، وهو ما يسمى بالخطأ المشترك الخد (الخطأ المساهم).

الحالة الأولى: الخطأ المستغرق بالخطن

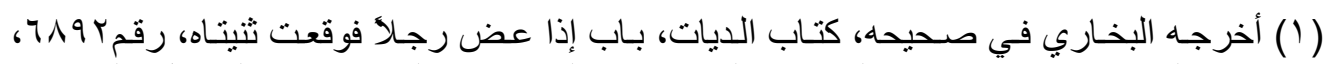

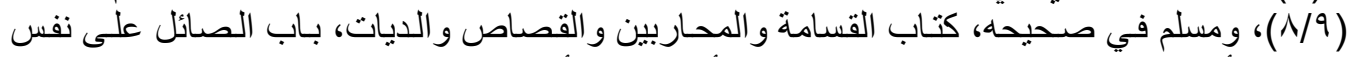

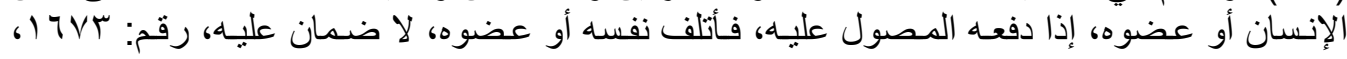


مفهومه: إذا وجد خطأ من المشرف وخطأ من الغير، و استغرق أحد الخطأين

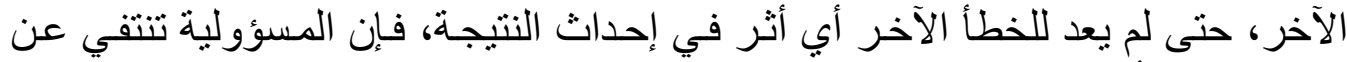
صاحب الخطأ المستغرق.

فإذا كان فعل المالك الخاطئ هو السبب الوحيد المنتج للضرر، اعتبر المشرف

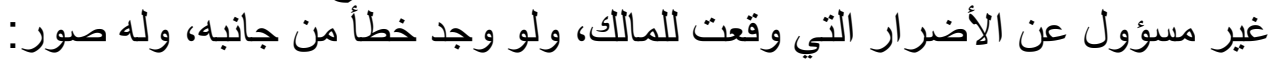

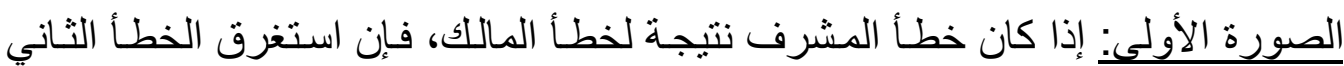

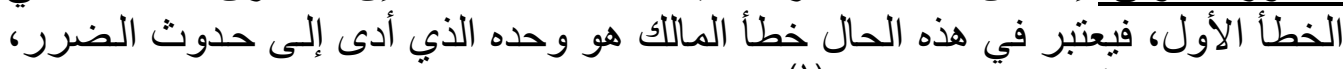

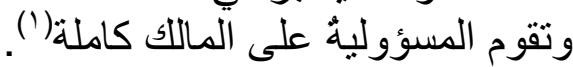

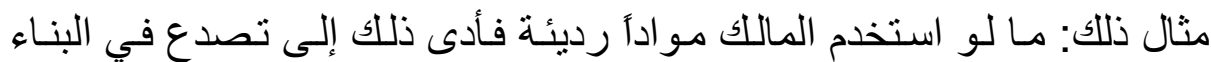

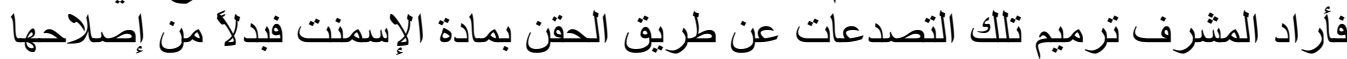

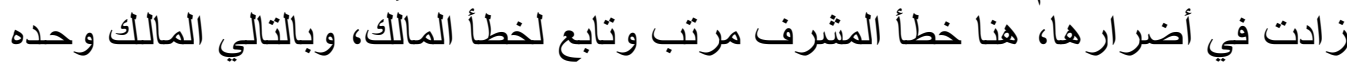
الذي يتحمل المسؤولية لكون خطأ المشرف تابعأ فرة لخطئه.

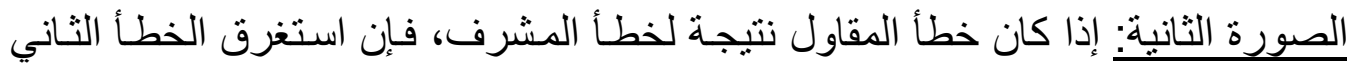

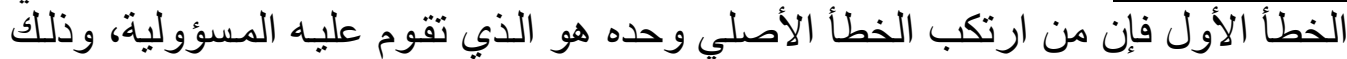

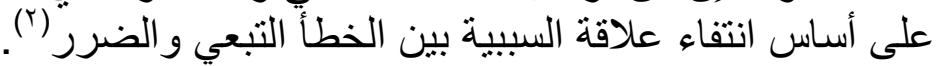

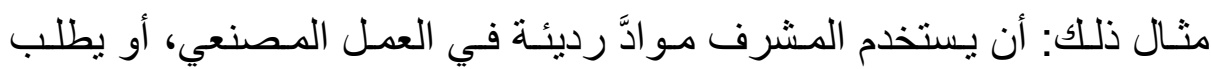

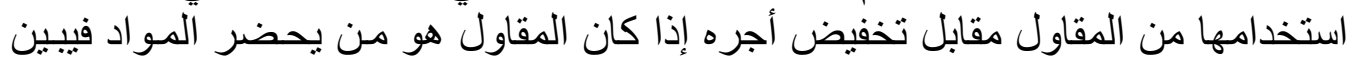

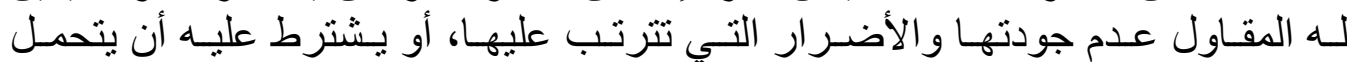

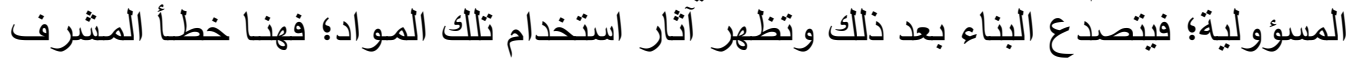
مستغرقٌ لخطأ المقاول؛ وبالتالي يتحمل المشرف وحده الثناء النتيجة دون المقاول.

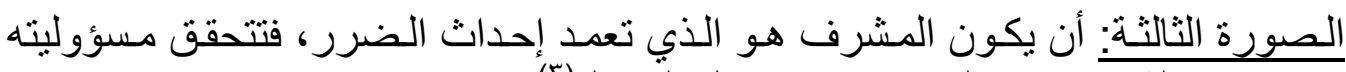

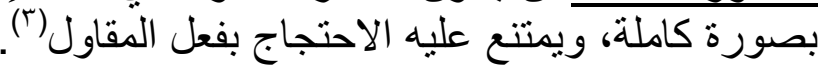

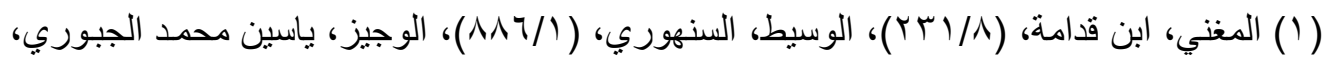
. (T. (T/T)

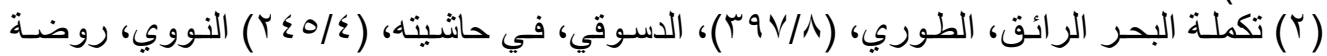

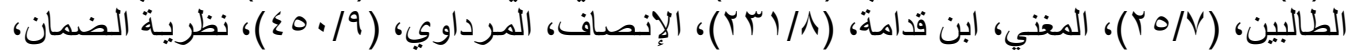

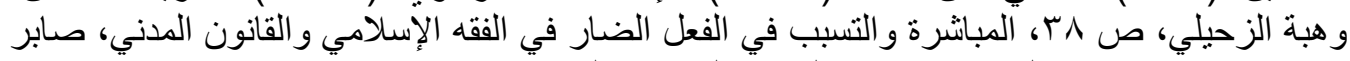

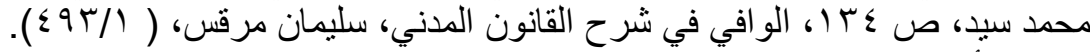

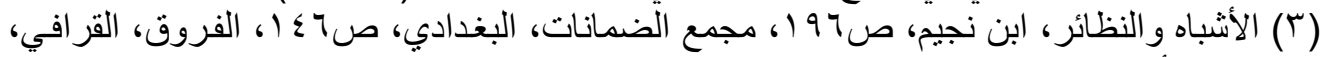

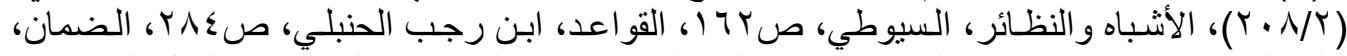

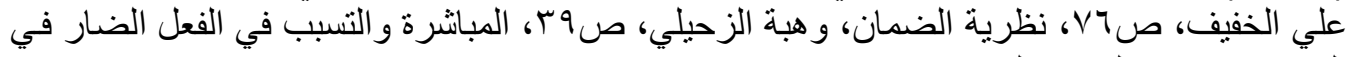

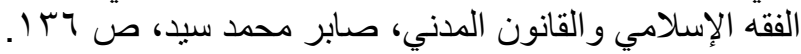


مثنال ذلك: أن يستخدم المشرف مو اداً قد اتفق معـه الماللك على عدم استخدامها

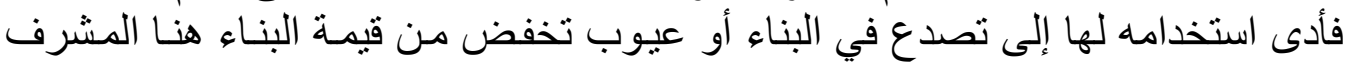
تعمد الخطأ ويتحمل المسؤولية كاملة.

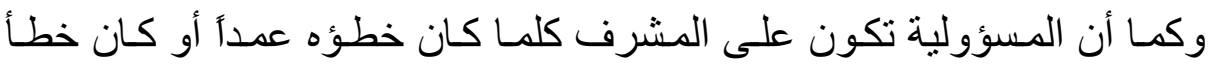
المالك نتيجة لخطأ المشرف كذللك تكون المسؤولية على المالك وحده إذا كان خطؤه عمداً أو كان خطأ المشرف نتيجة له لهأ.

الحالة الثانية: أن يشترك كلا الخطأين في إحداث الضرر دون استغراق، وهو ما يسمى بالخطأ المشترك (الخطأ المساهم). مفهومه: أن يساهم خطأ المشرف مع خطأ المقاول في إحداث الضرر.

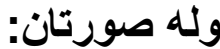

منهما('). الصورة الأولى: إذا كان الضرر واقعاً على أحدهما، كان الضمان عليهما بنسبة خطأ كل

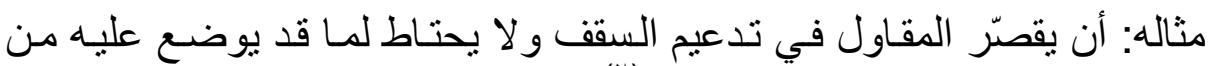

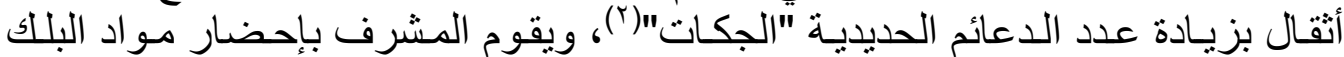

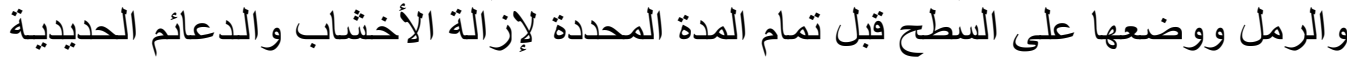

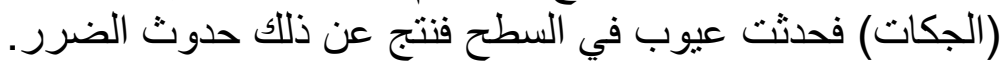
فيكون الضمان عليهما بنسبة تأثثر خطأ كل منهما، ويرجع في تقدير نسبة الخطأ

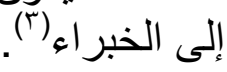

الصورة الثانية: إذا كان الضرر و اقعأ عليهما كليهما.

مثنال ذلك: أن يتأخر المشرف في تأمين المواد اللازمـة لإنجاز العمل، ويتأخر

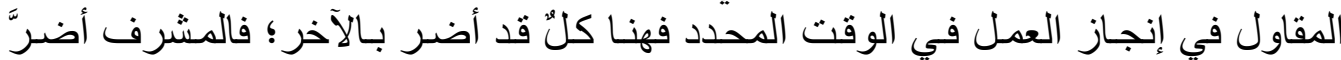

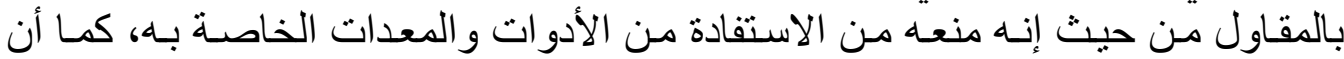

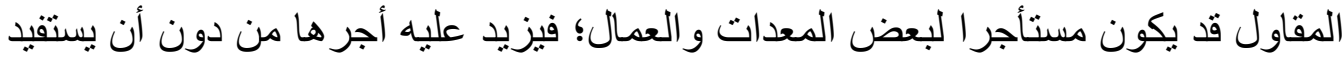

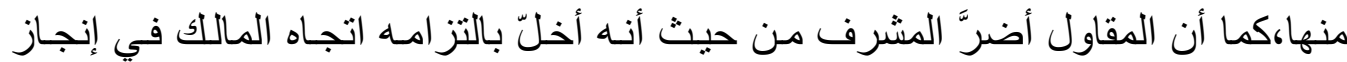

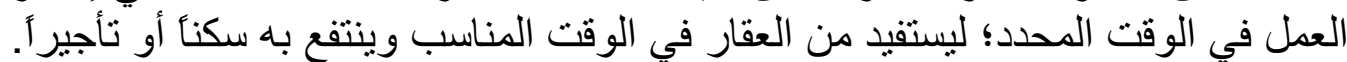

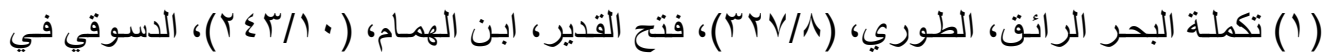

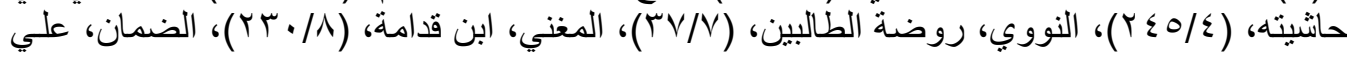

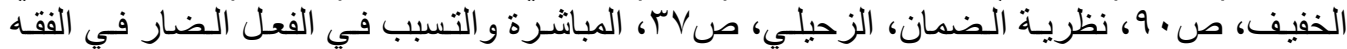

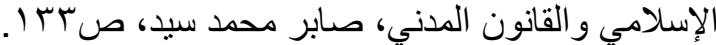

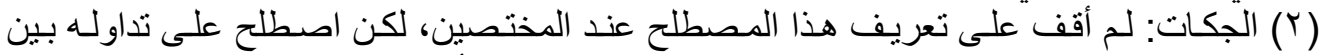

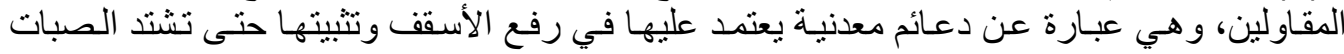
الخر اسانية ويعتمد على صلى صلابنها.

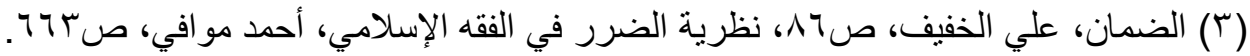




\section{اختلف العلماء في كيفية توزيع المسؤولية بينهما على قولين:}

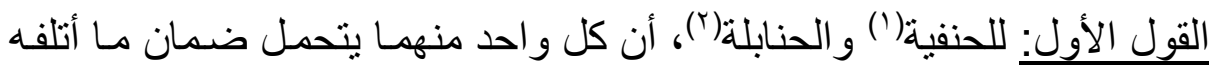

على الآخر.

فإذا اشترك السائق والمتضرر في إحداث الضرر، كان على كل واحد منهما

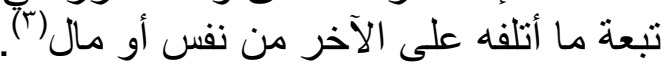

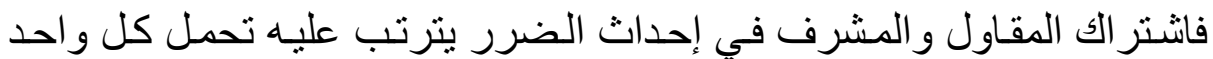
منهما تبعة ما أتلفه على الآخر.

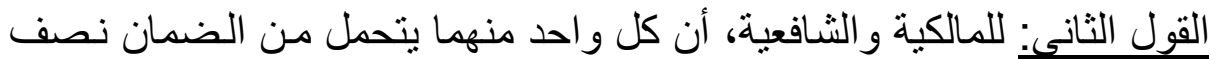

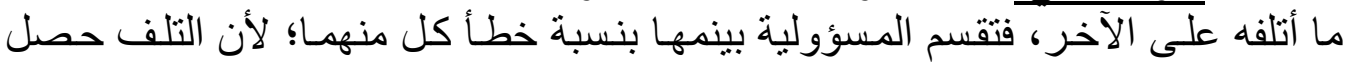
بفعلهما، فكان الضمان منقسما عليهما.

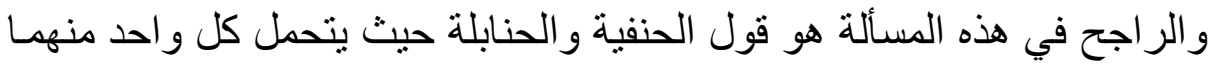

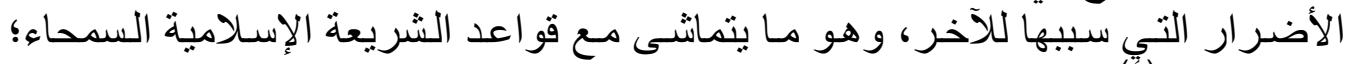

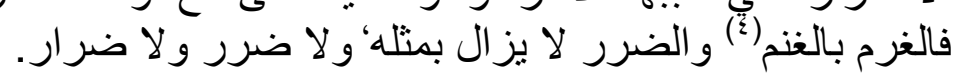

وفي حال عدم إمكانية تحديد مسؤولية كل منهما يُقسم الضمان بينهما بالتساوي.

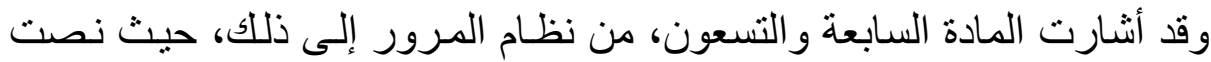

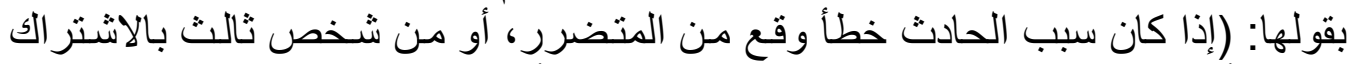

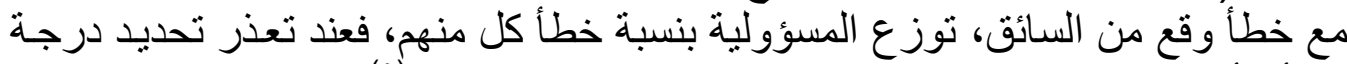

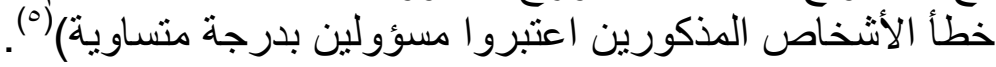

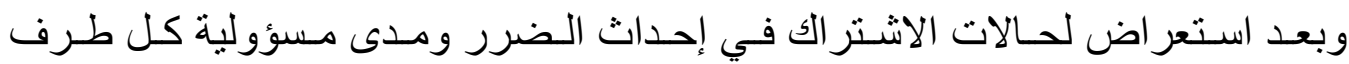

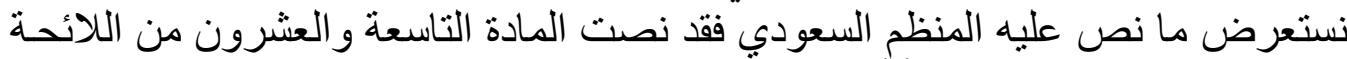

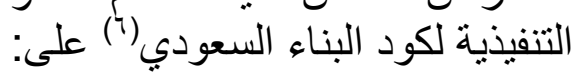

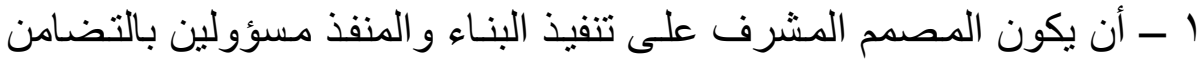

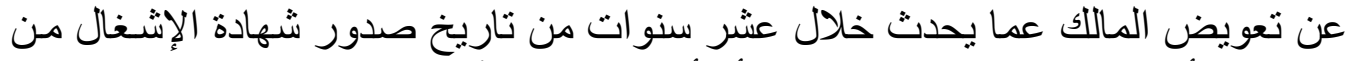

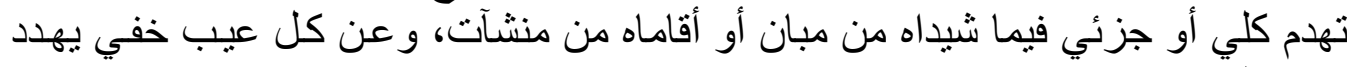
متانة البناء وسلامته.

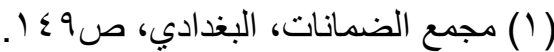

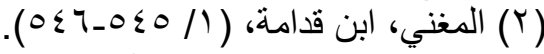

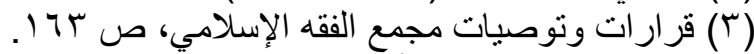

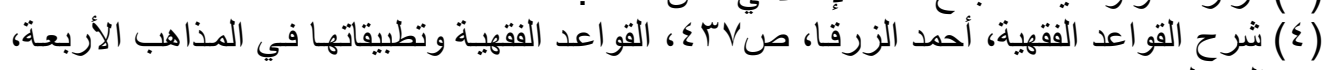

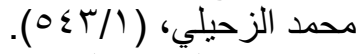

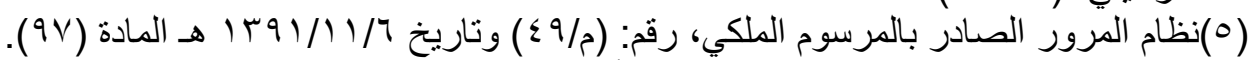

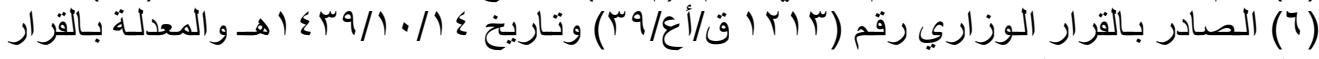




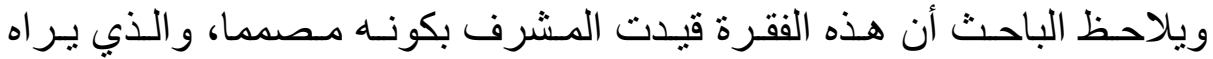

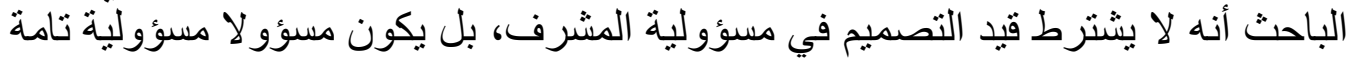
بالتضامن مع المنفذ، و إن لم يكن مصممأ.

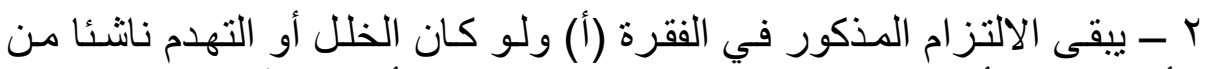
عيب في الأرض ذاتها أو رضي صاحب العمل بإقامة المباني أو المنشآت المعيبة.

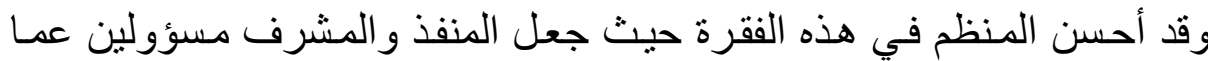

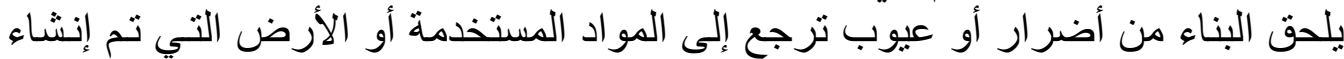

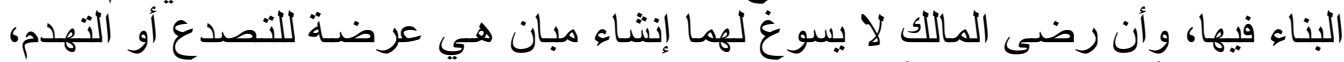

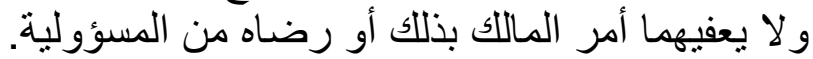

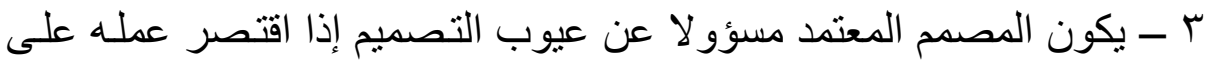
وضع التصميم فقط دون الإشر اف على التنفيذ.

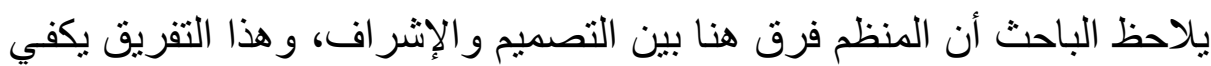
لإبر از دور المشرف ومدى مسؤوليته عن أعمال الإشر اف الف التي يتو لاهيا.

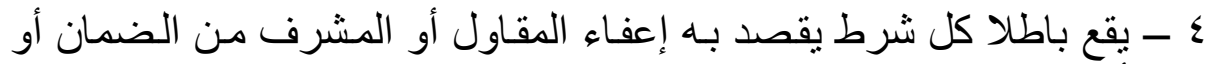

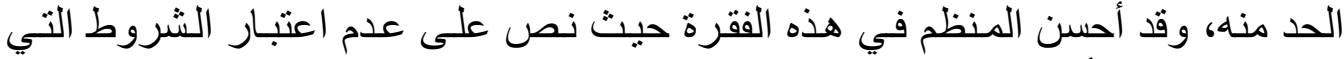

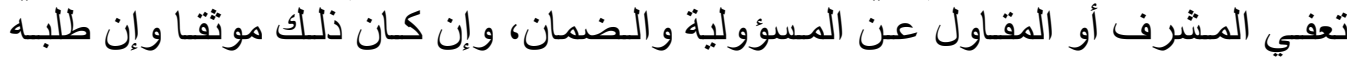

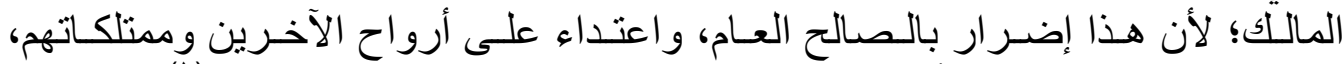

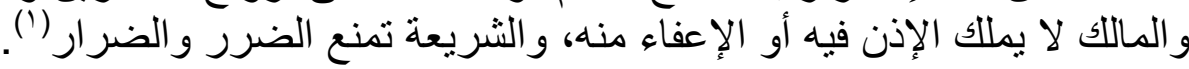

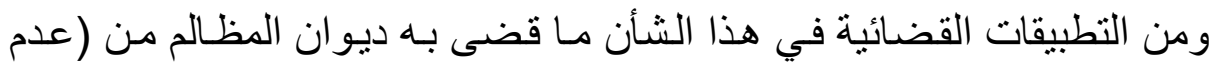

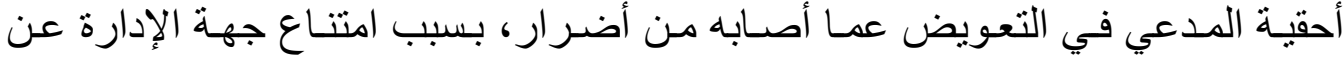

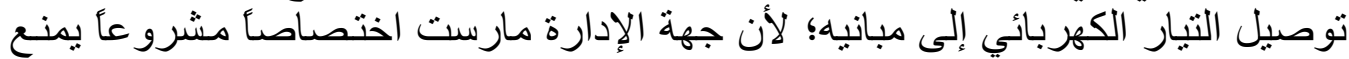

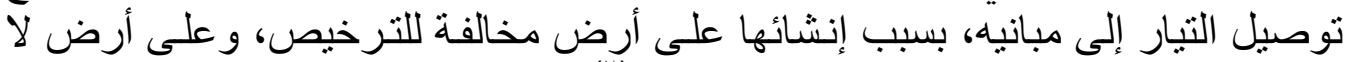

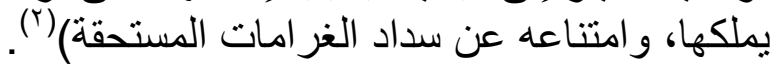
ففي هذه الحالة لا يكون المشرف مسؤولا عن الخطأ ولا يتحمل شيئا من نتائجها مالم يكن هو السبب في البناء بأرض الخي الغير.

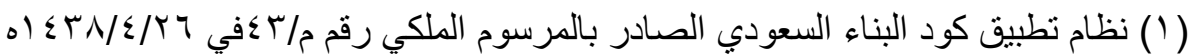

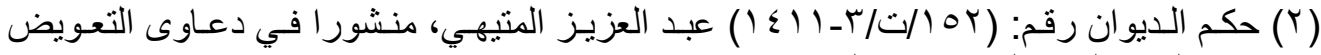

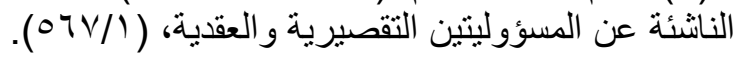




\section{المبحث الرابع}

\section{التعوبض عن الضرد}

يلتزم المشرف بمقتضى العقد بالتزامات الأجير المشترك أو الخاص و إذا أخل بالتز اماته

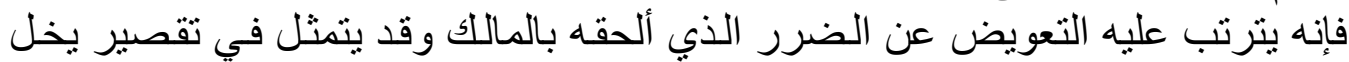

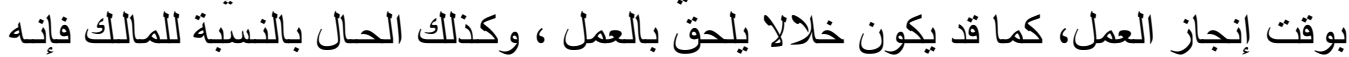

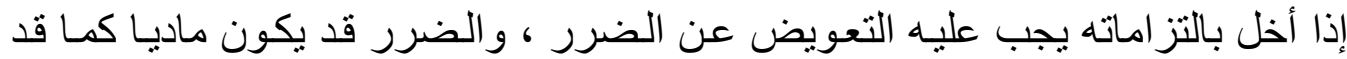

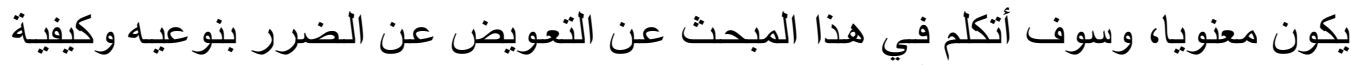
تقديره من خلال المطالب الآتية.

\section{المطلب الأول}

\section{الضرر الماديى}

يجب على محدث الضرر أن يعوض المضرور عمـا لحقهه مـن ضرر ،والضرر المـادي يأخذ أشكالاً أبرزها: 1 - ضرر التأخير في تسليم العمل:

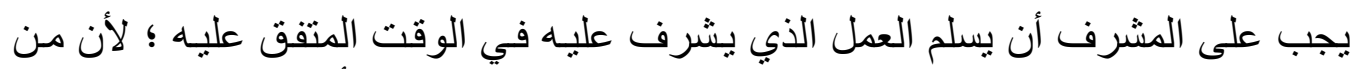

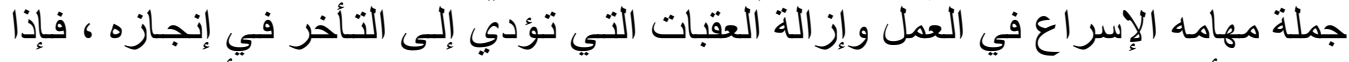

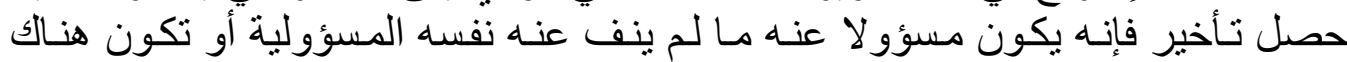

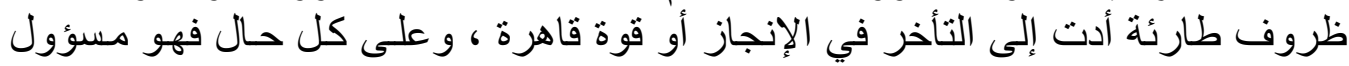

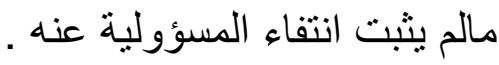

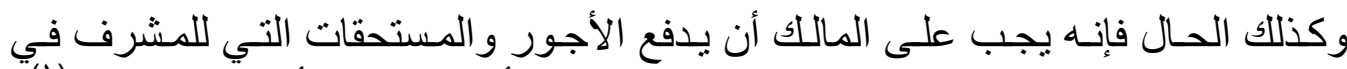
الوقت المتفق عليه، وإلا فلا حق له في مطالبته بعدم التأخر في تنفيذ أعمالّه وتسليمهاب(').

بـ الضرر الحاصل بسبب عدم تسليم العمل الذي يشرف عليه بعد الانتهاء منه.

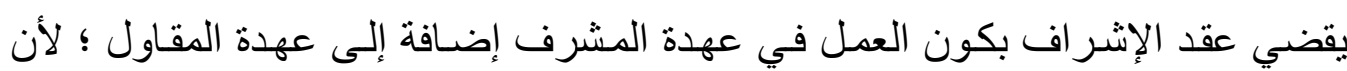

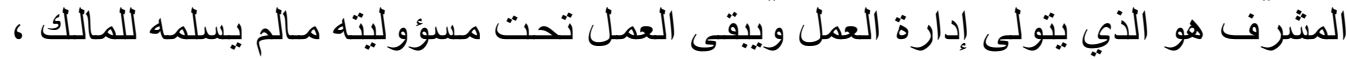

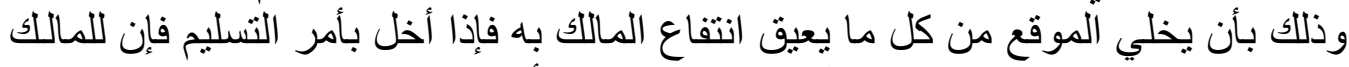

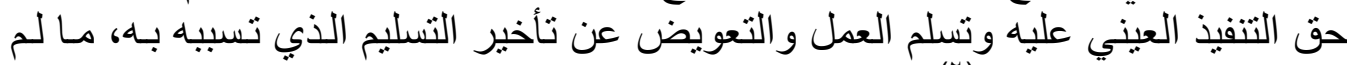

ينف عن نفسه المسؤولية)(ب)

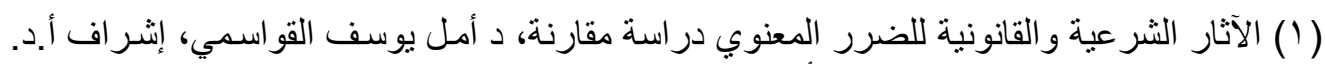

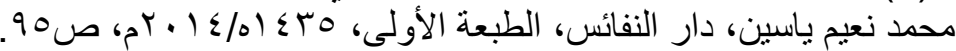

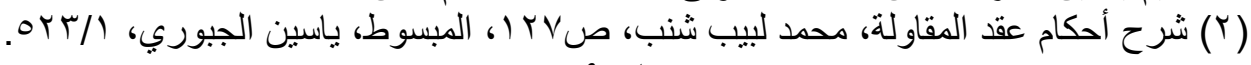




$$
\text { هـ - الضرر الحاصل بسبب العيوب في العمل: }
$$

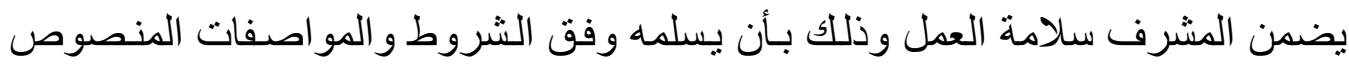

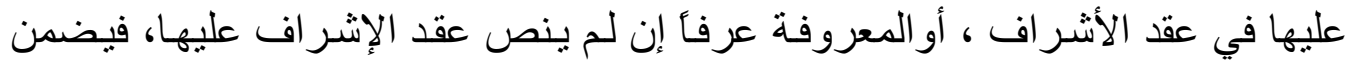

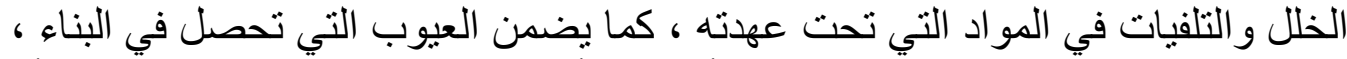

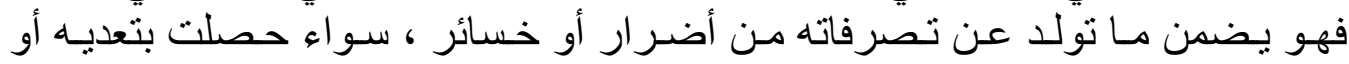

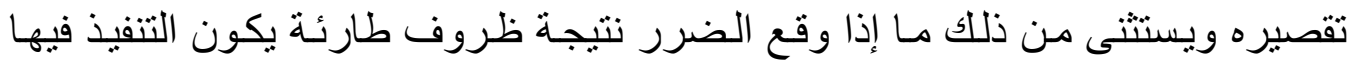
مر هقا أو قوة قاهرة لايمكن دفعها و لايمكن توقعها ويستحيل تنفيذ الالتز ام بسبيها.

\section{المطلب النانبي}

\section{الضرر المعنوبي}

يجب على من يتسبب بالضرر المعنوي أن يعوض المضرور عنه والضرر المعنوي قد

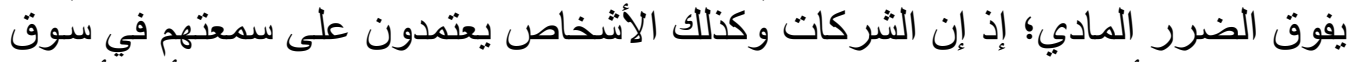

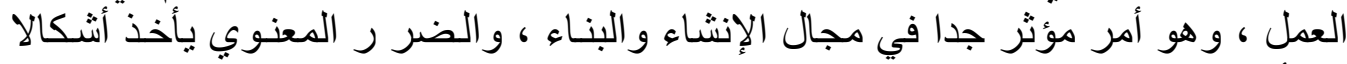
من أبرزها:

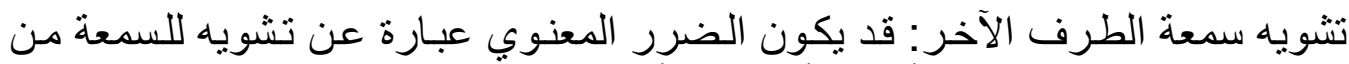

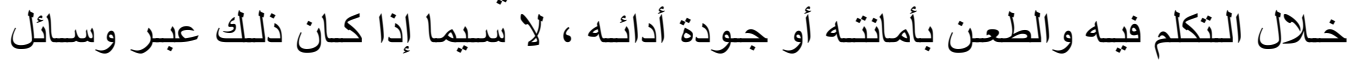

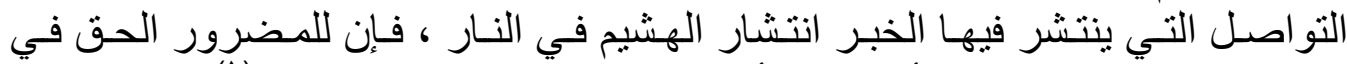

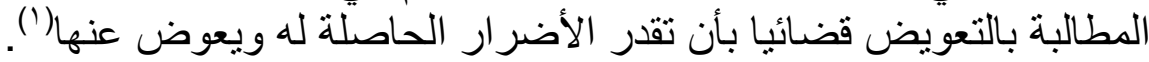

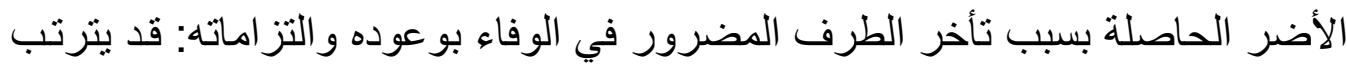

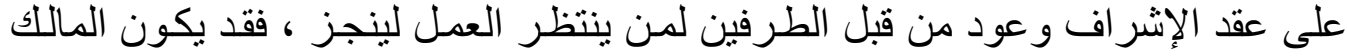

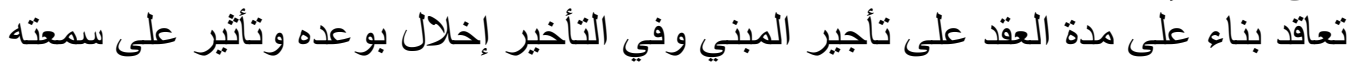
، كما قد يكون المشرف تعاقد على عمل بناء على المدة المتوقعة لعقد الإشر اف ففاته ذلاتلك

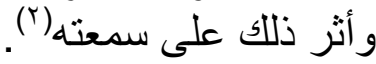

\section{المطالب الثنالث}

\section{تقدير التنعويضز}

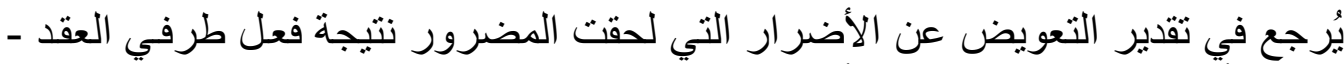

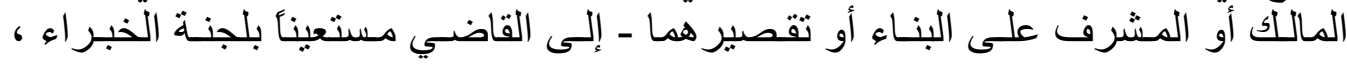

(1) الفعل الضار، مصطفى الزرقا، صع با، التعويض عن الضرر في الفقه الإسلامي، د.محمد بن

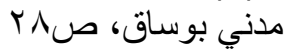

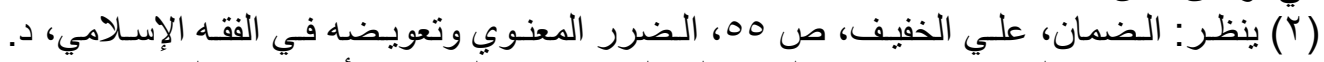

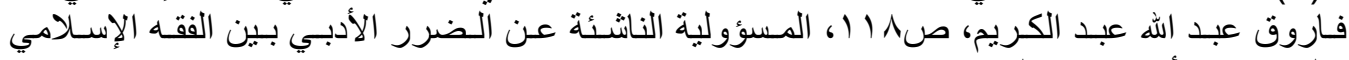

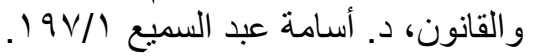




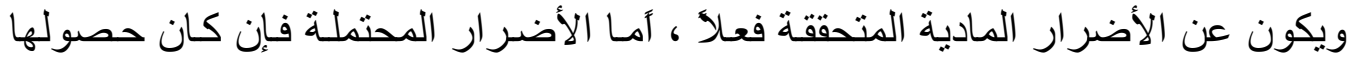

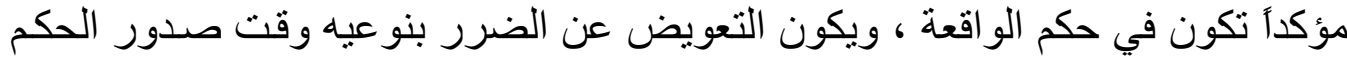

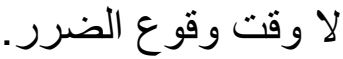
التعويض عن الضرر المادي: للقاضي سلطة تقديرية في التعويض، ويمكن أن يكون التعويض: التصدي:

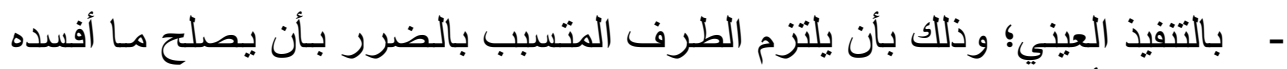

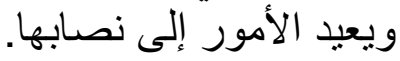

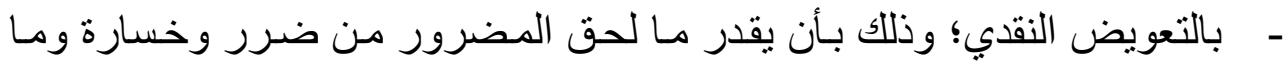

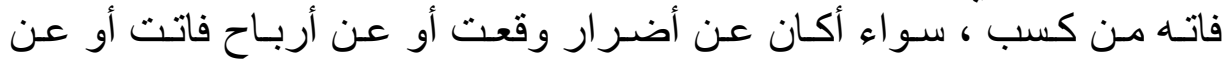

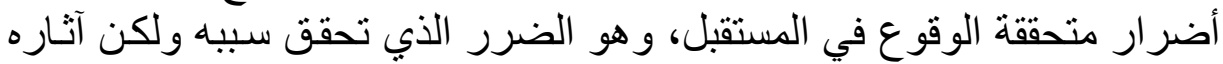
لن تظهر إلا في المستقبل. - - للقاضي أن بحتفظ للمتضرر بطلب الحق و إعـادة النظر في تقدير التعويض في

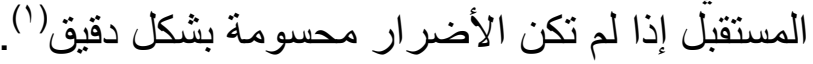

التعويض عن الضرر المعنوي: للقاضي أيضا سلطة تمكنه من الحكم بالتعويض عن الضرر المعنوي، والتعويض يأخذ

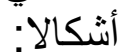
- - أن يكون التعويض معنويــ؛ مـن خـلال إلز ام المعتدي بالاعتذار ورد الاعتبـار للمضرور؛ عبر الصحف و المونو اقع الرسمية.

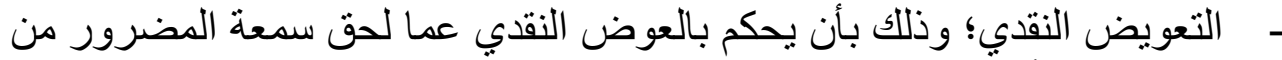

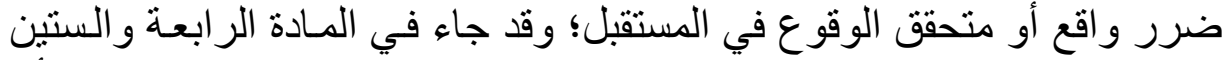

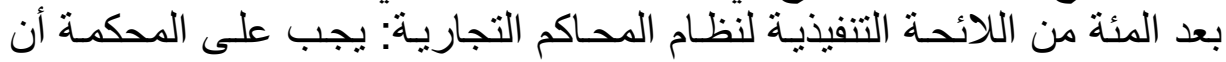

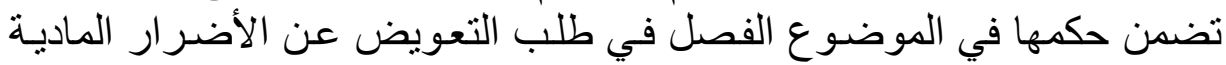

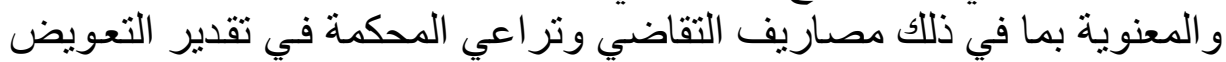
الآتي:

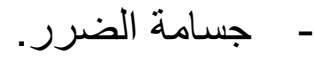

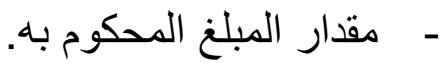
- - العرف أو العادة المستقرة.

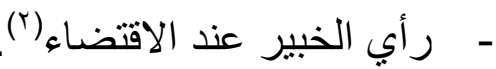

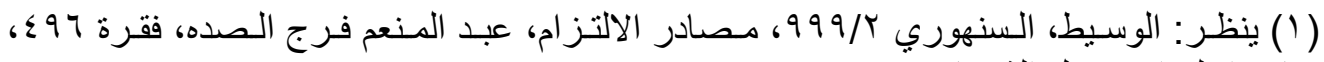

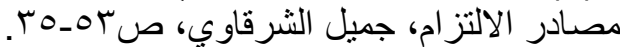

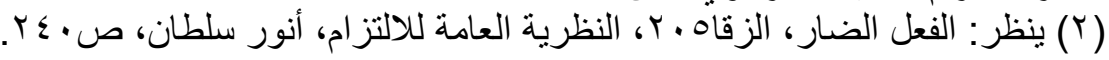




\section{المطلب الرابـ}

\section{انتهاء عقد الإشراف}

\section{ينتهي عقد الأشراف وتنقضي آثاره في إحدى الحالات التالية:}

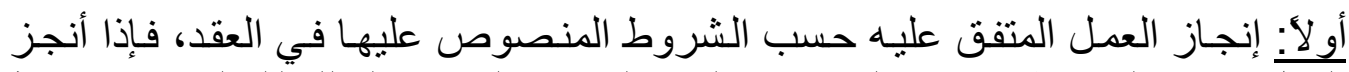

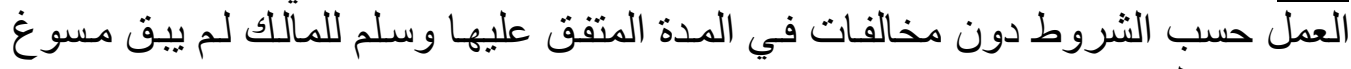

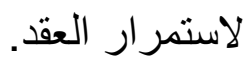

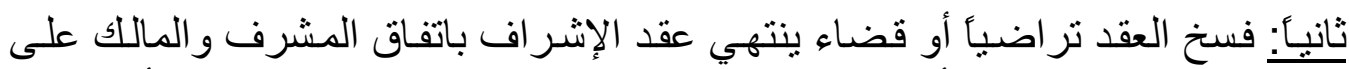

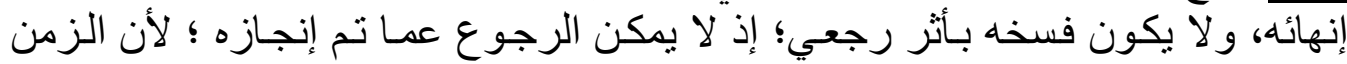
الذي يستغرقه العمل الإشر افي لا يمكن إرجاعه.

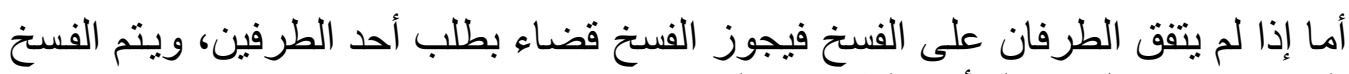
القضائي في حال إخلال أحد الطرفين بالتز اماته.

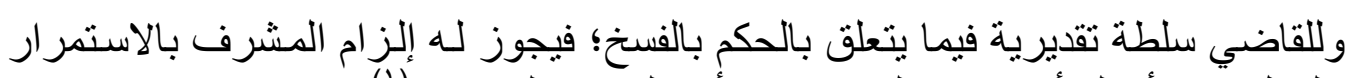

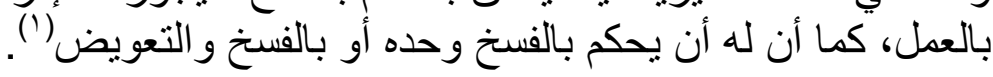

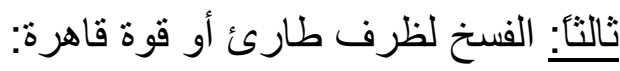

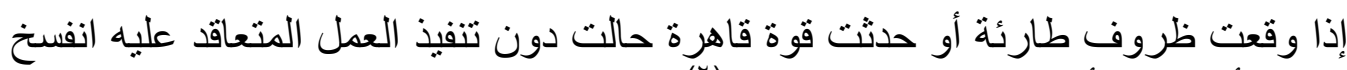

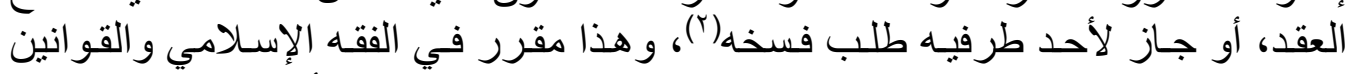

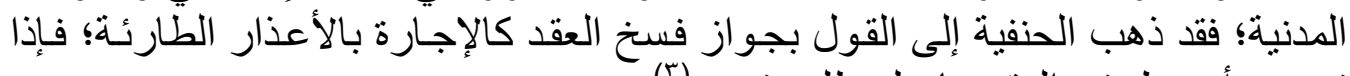

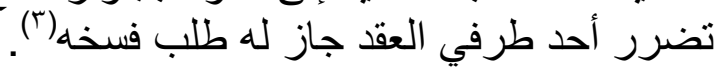

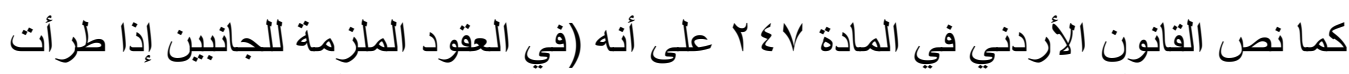

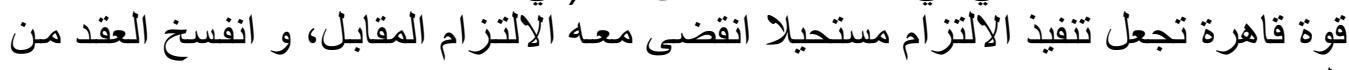
تلقاء نفسه)

$$
\text { رابعأ: موت المشرف: }
$$

ينتهي عقد الإشر اف بموت المشرف أو فقده أهلية العمل ،ويستحق ورثته قيمة الإثر اف

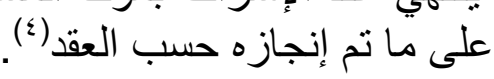

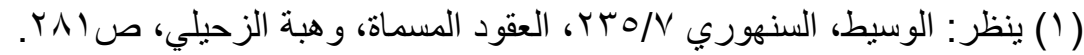

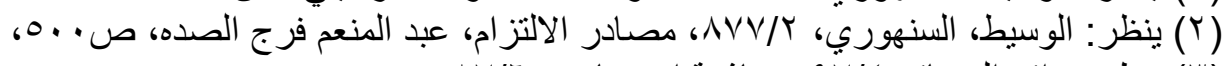

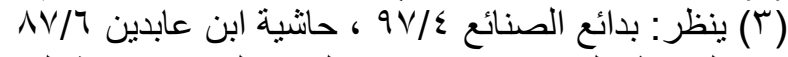

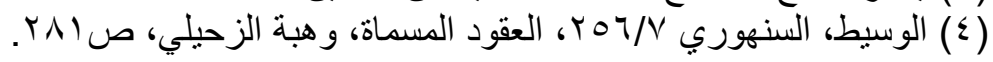




\section{الخاتمة}

الحمد لله الذي بنعمته تتم الصالحات بعد الفراغ من البحث توصل الباحث إلى

جملة من النتائج و التوصيات.

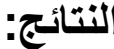

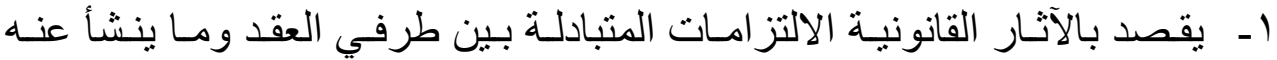
الالتز ام التعاقدي من ضمانات وتعويض عن الأضر ار المادية و المعنوية.

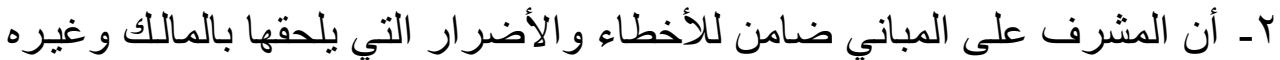

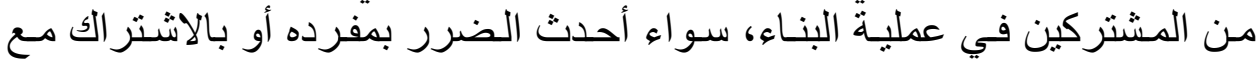
غيره.

r- أن النظام لـم يبين حقيقة الترخيص المعتبر في حق المشرف، وهل هو خبرة علمية أو عملية أو مزيج منهما.

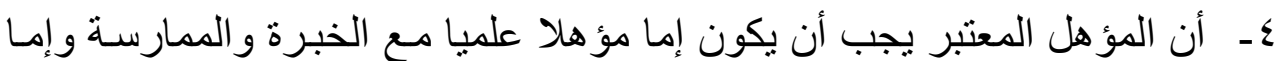

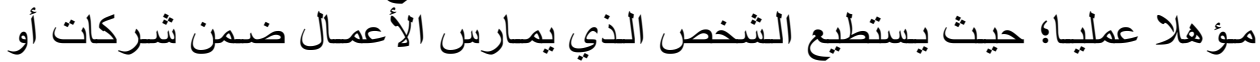
مؤسسات الحصول على شهادة خبرة تدل على مهارته و أهليته.

0ـ يعفى المخطئ من آثار الخطأ الذي ارتكبه إذا كان نخطأ غيره مستخرقا لخطأ. جـ القوة القاهرة و الظروف الطارئة قد يعفيان عن المسؤولية الحاصلة بسببهما وقد

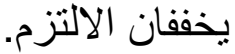
V- إذا اجتمع المباشر و المتسبب فإن المباشر يكون هو المتحمل للآثار والأضـرار

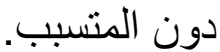

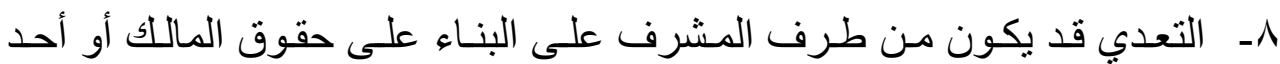

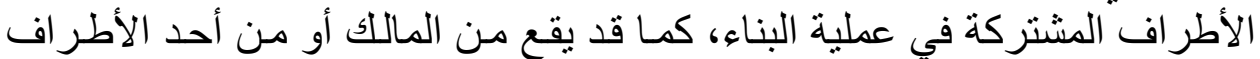

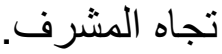
9- القيام ببعض الأعمال التي تقع على عاتق رب العمل، أو على عاتق المقاول أو المهندس أو الفني. • ا ـ يُشترط في الأجر على الإشـر اف أن يكون معلومـا ومشرو عاومقدورا على

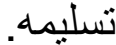

1 ا ـ أن التعدي الحاصل من مشرف البناء يكون بمخالفة نص العقد، وكذلك بمخالفة

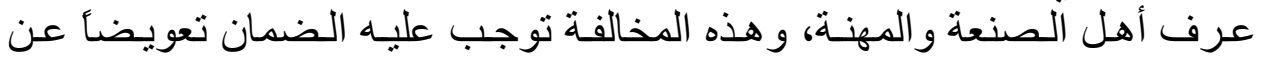
الضرر الذي لحق المالك نتيجة لتقصير المشرف في إخلاله بمهامهاه ومنابعة أعماله

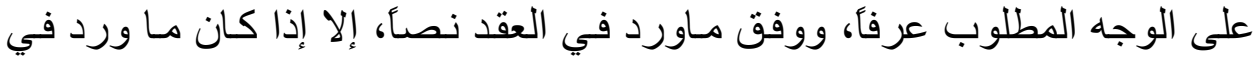
العقد يخالف نص النظام عند ذلك يجب العمل بما نص عليه النس النظام. 


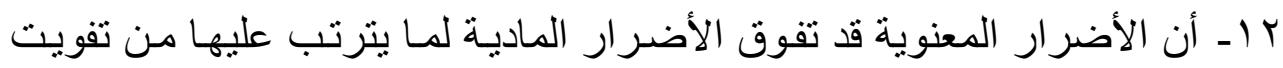

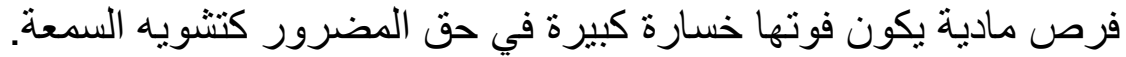

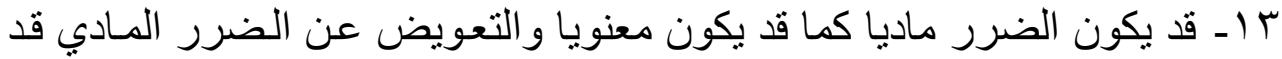
يكون معنويا كما قد يكون ماديا. ع ا ـ للثاضي سلطة تقديرية يسنطيع من خلالها أن يقدر الضرر بالتعاون مـع لجنـة الخبر اء.

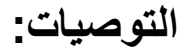
يوصي الباحث بجملة من التوصيات، وهي:

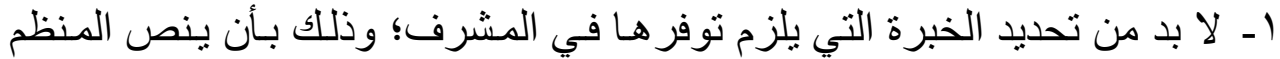

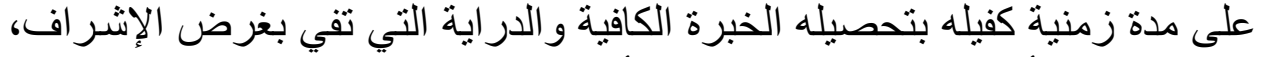
ويرى الباحث أن تكون بـ سنو اته على على الأقل

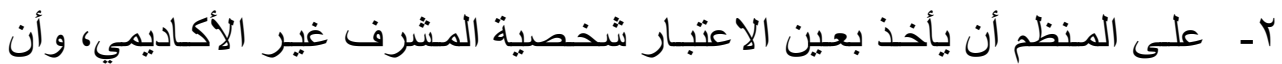

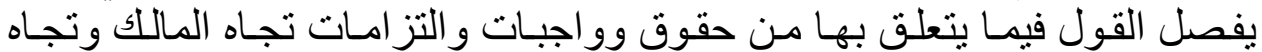

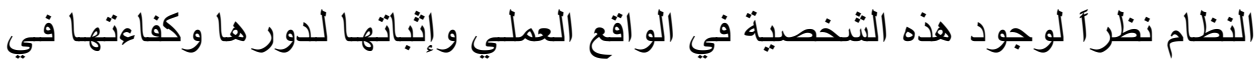

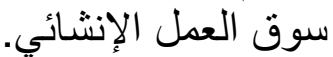

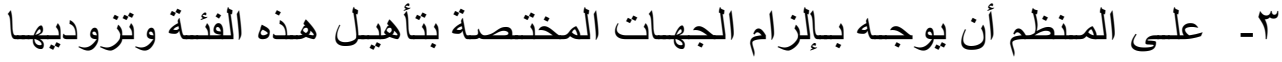
بالمهار ات والخبرات اللازمة من خلال بر امج عملية وعلمية تعد لهذا الغرض.

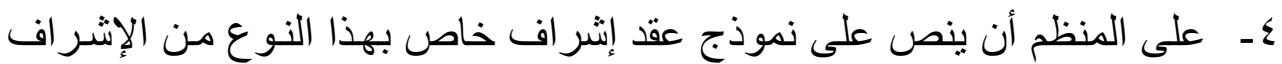

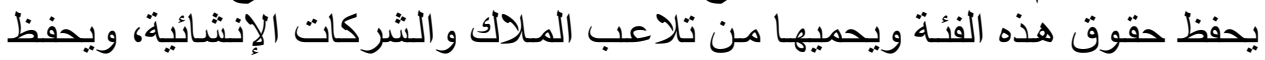
حقوق الأطر اف التي يتعاملون معها.

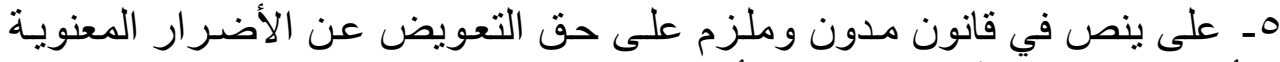
لأنها قد تفوق في آثار ها المادية الأضر ار المادية المبادئ الترة. 
ا الأحكام السلطانية، أبو الحسن علي بـن محمد بـن محمد بـن حبيب البصري

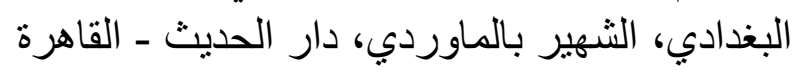

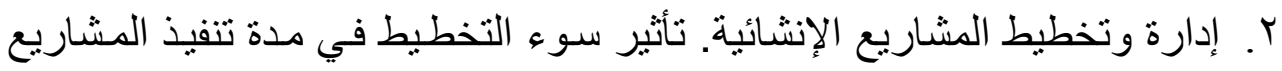

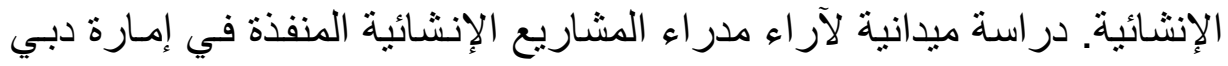

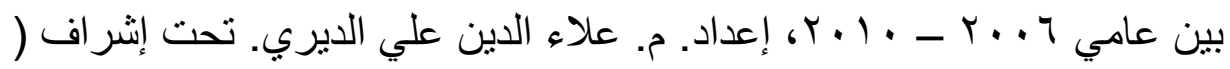

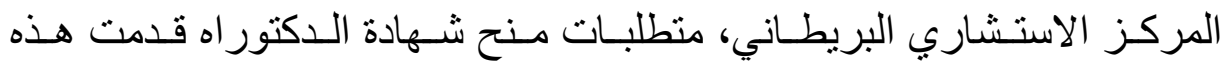

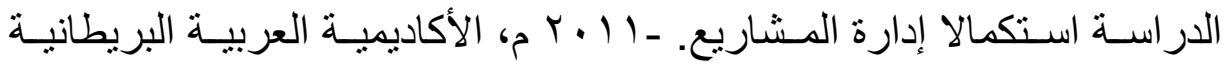
للتعليم العالي.

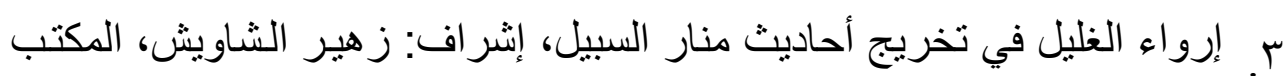

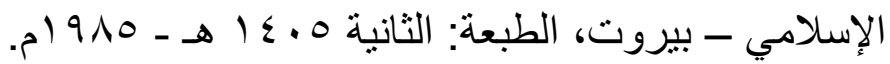

ع. الأشباه و النظائر على مذهب أبي حنيفة النعمان، زين الدين بن إبر اهيم بن محمد،

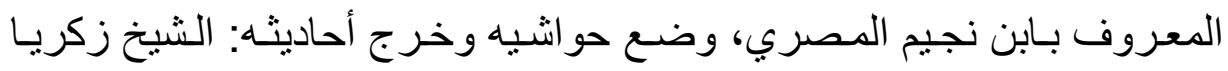

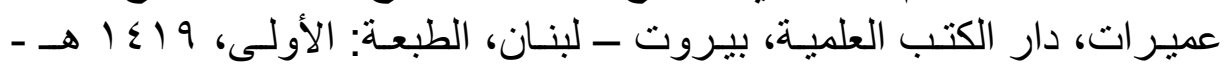
. 1999

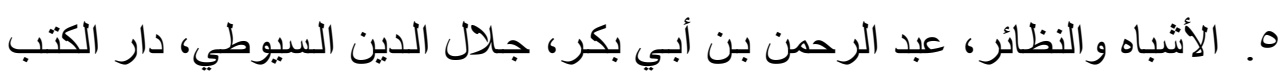

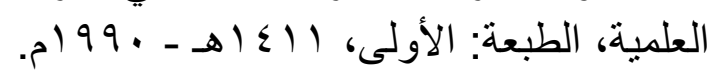

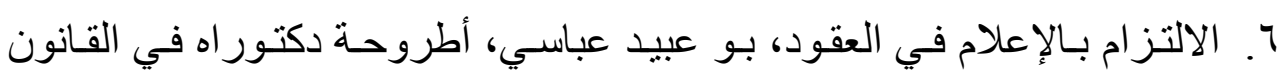

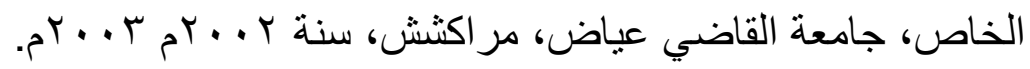

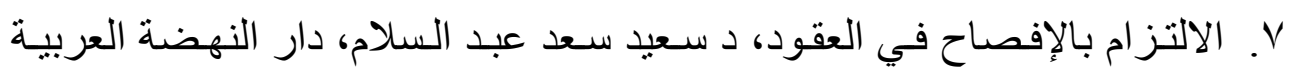
. 1999

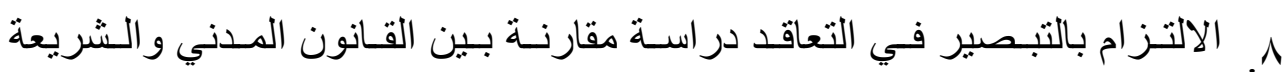

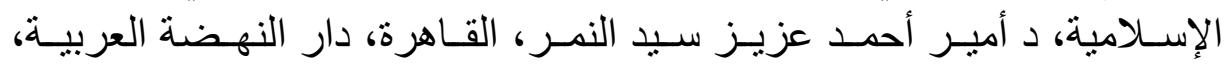
. $1 \mathrm{r}$

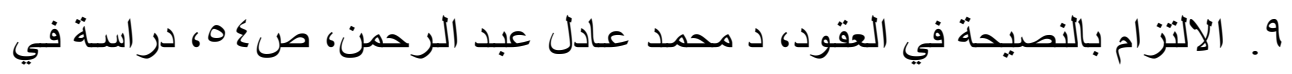

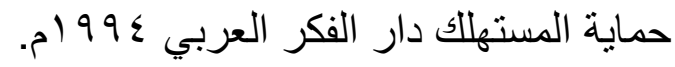

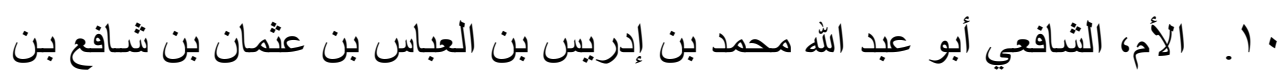

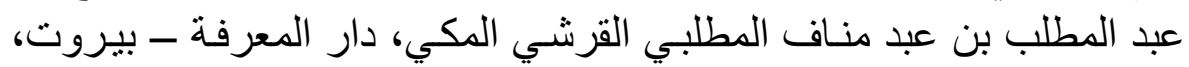

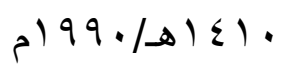




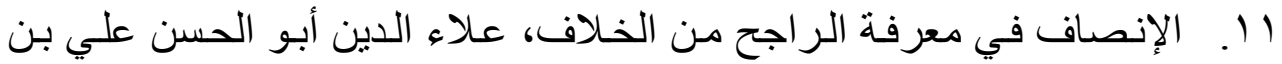

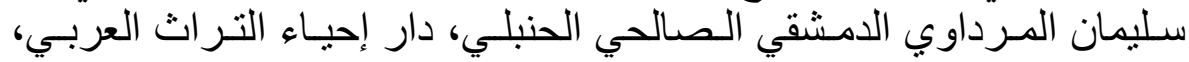
الطبعة: الثانية.

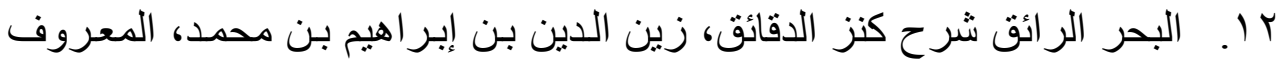

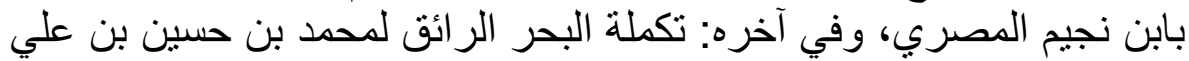

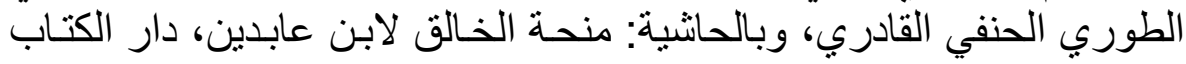
الإسلامي، الطبعة: الثانية.

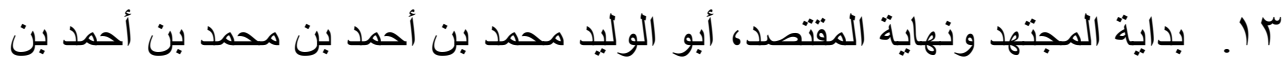

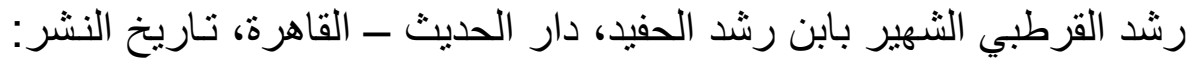

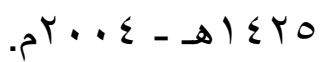

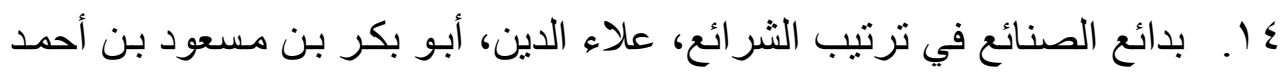

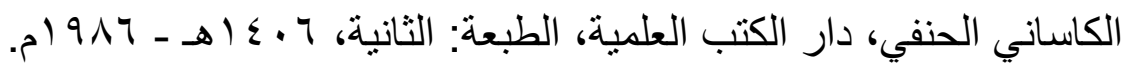

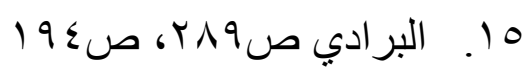

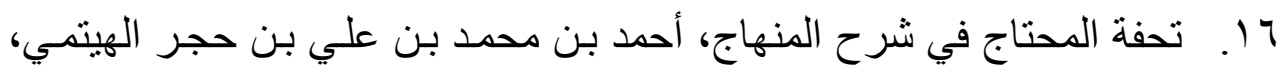

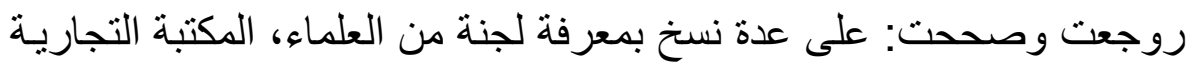

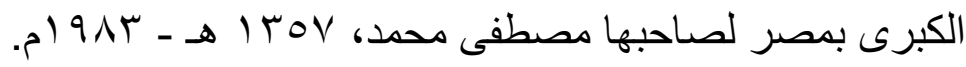

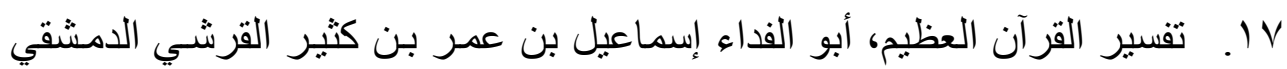

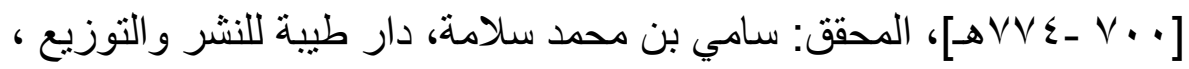

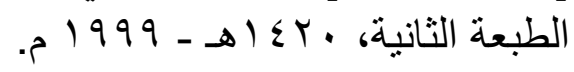
1 1. التكييف الثرعي والقانوني للمسؤولية المدنية الناثئة عن مضسار الجوار، مراد

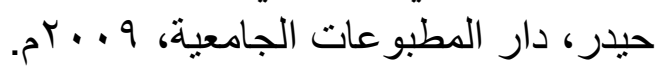

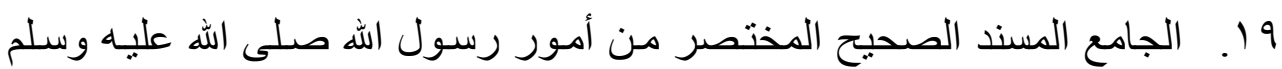

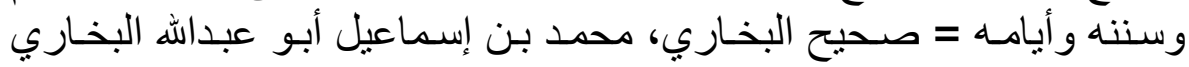

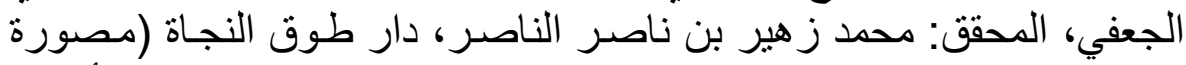

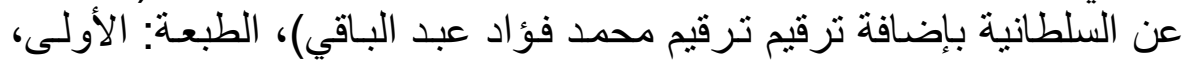
(ه

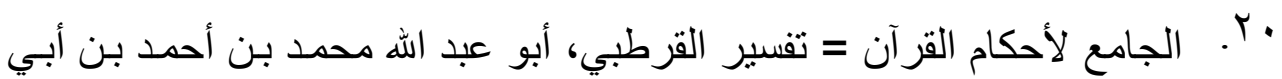

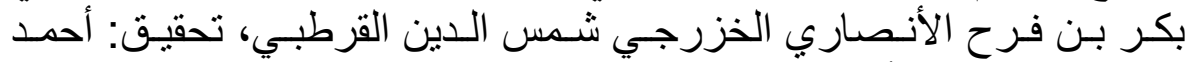

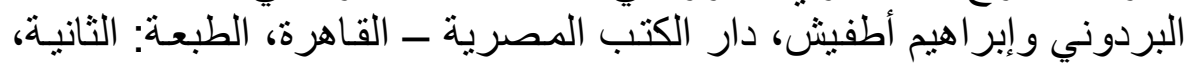
ع آهـ 


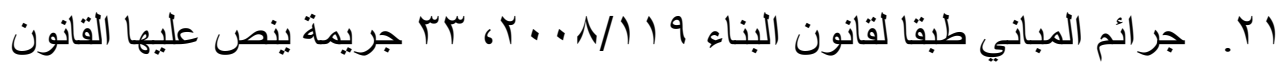

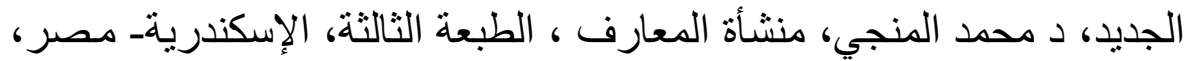
. 1 .

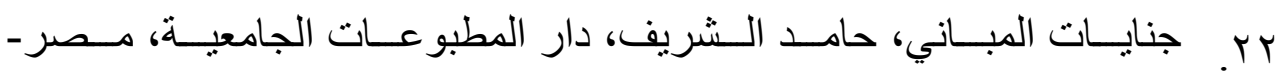

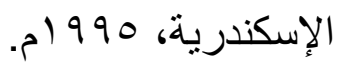

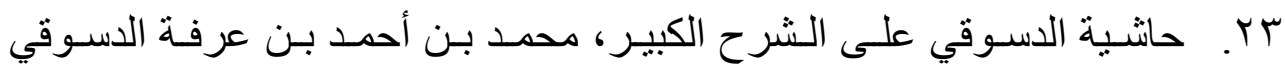
المالكي، دار الفكر . الفئ.

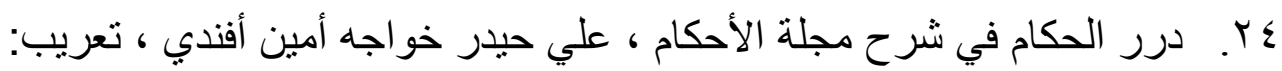

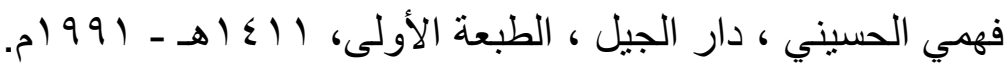

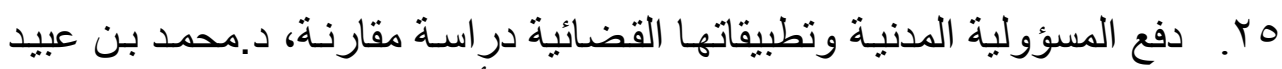

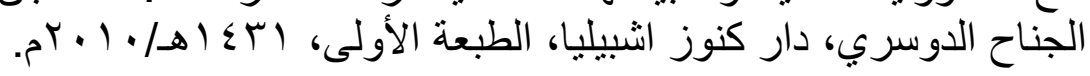

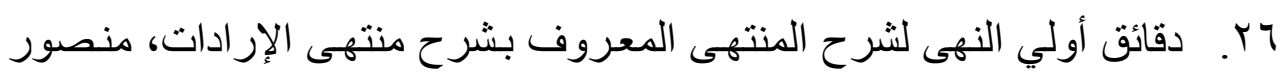

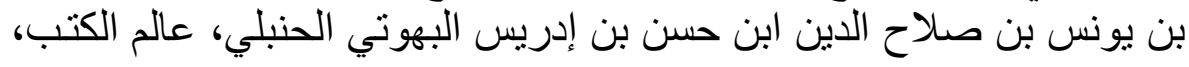

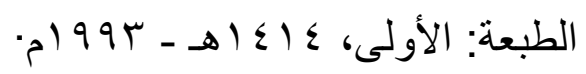

rV

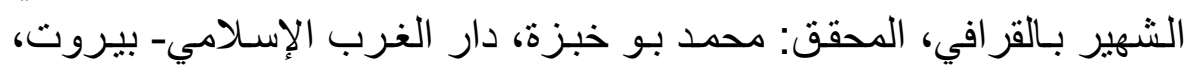

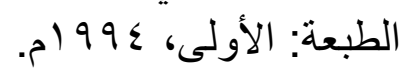

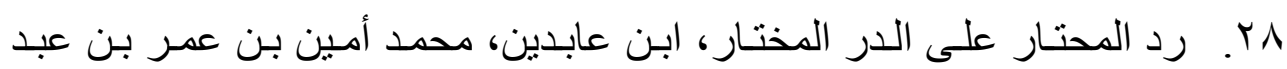

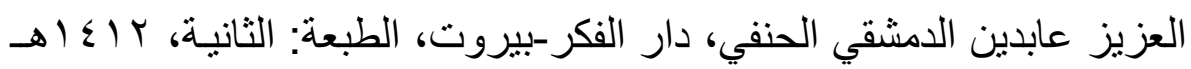

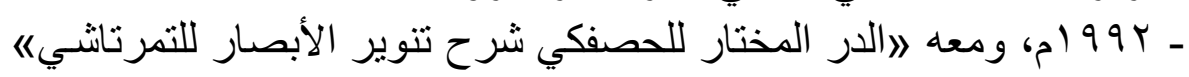

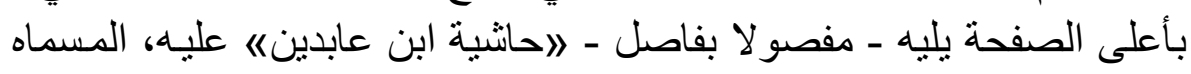

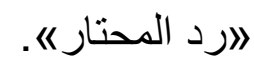

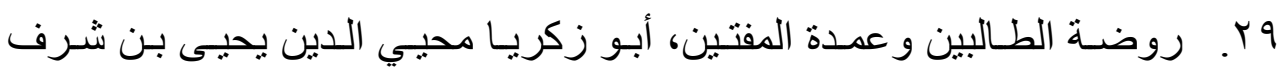

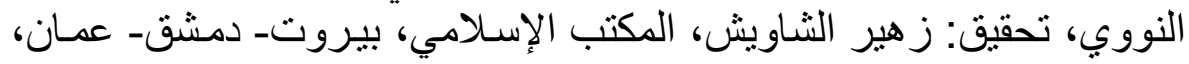

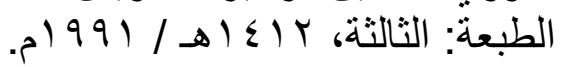
•r. . سعوديون يستثرون في الإشر اف على المباني ويز احمون العمالة الأجنبية،

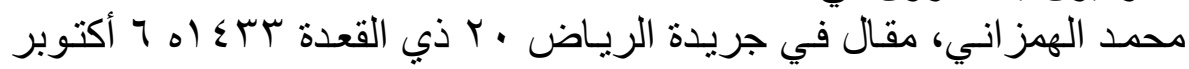

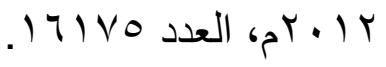




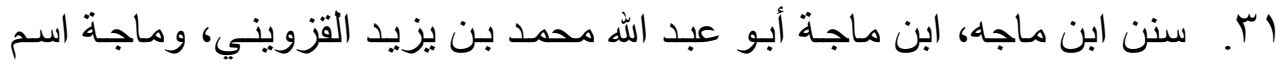

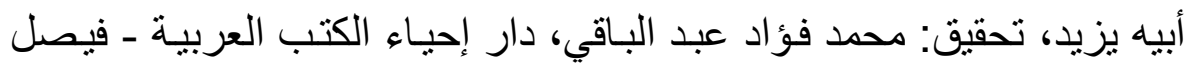

$$
\text { عيسى البابي الحلبي. }
$$

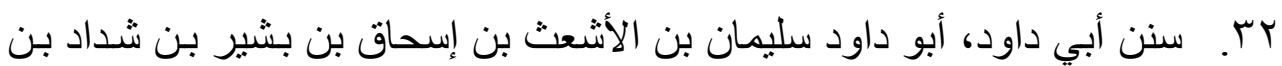

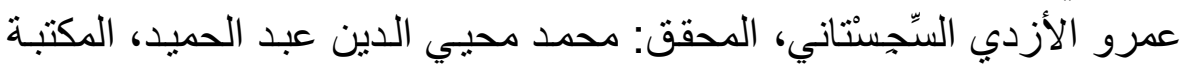

$$
\text { العصرية، صيدا - بيروت. }
$$

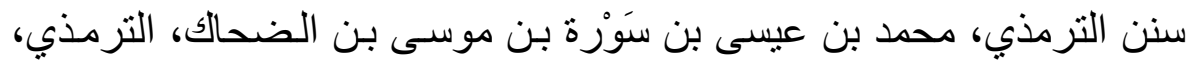

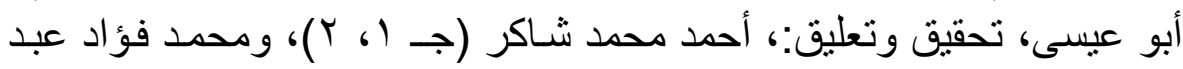

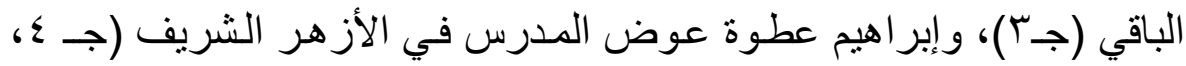

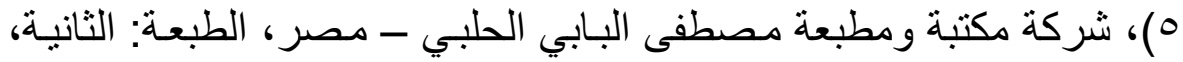
. ) $9 \vee 0-11790$

ع ا. شرح التلويح على التوضيح، سعد الدين مسعود بن عمر التقتاز اني، مكتبة صبيح بمصر.

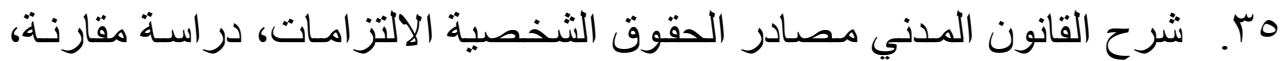

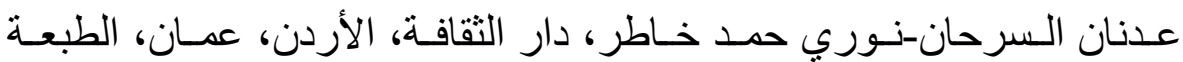

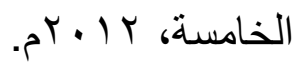
דr. شرح القو اعد الفقهية، تأليف: أحمد بن الثيخ محمد الزرقا، الطبعة الثانية بقلم:

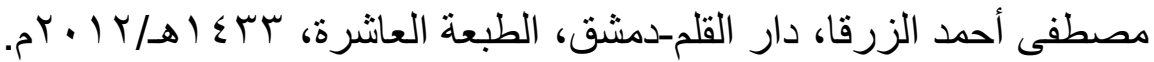
rV

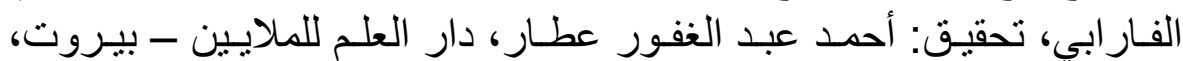

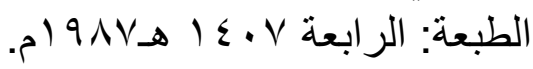

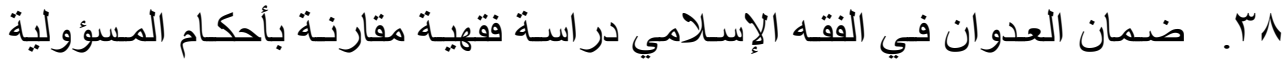

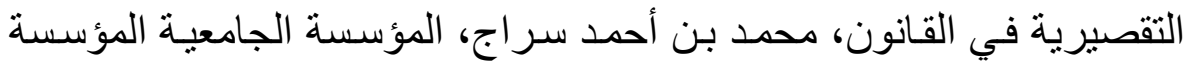

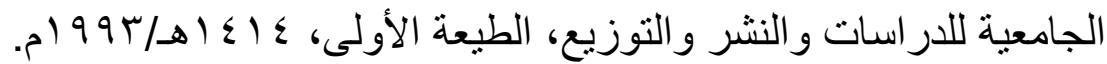
qج. ضمان المتلفات في الفقه الإسـامي، د/ سليمان محمد أحمد، مطبعة السعادة،

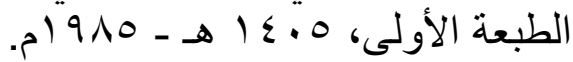
•ـ. الضمان في الفقه الإسلامي، علي الخفيف، المطبعة الفنية الحديثة.

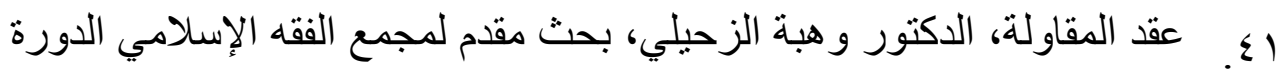

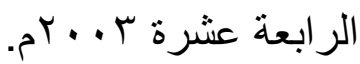


عقد تقديم المشورة -در اسة قانونية لعقد تقديم الاستشارة الفنية، حسن حسين

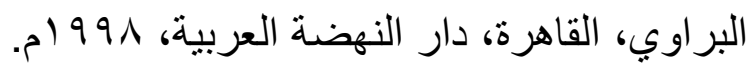
$\varepsilon r$

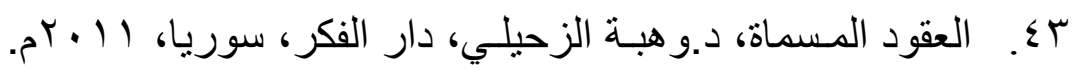

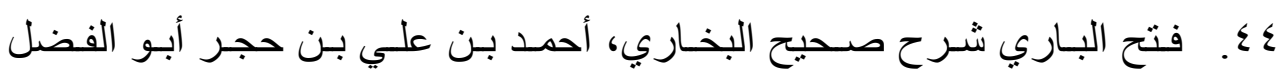

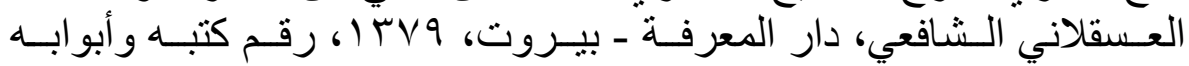

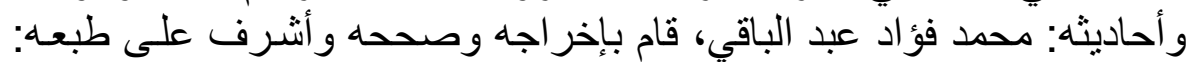
محب الدين الخطيب، عليه تعليقات العلامة: عبد العزيه والديز بن عبد الله بن باز.

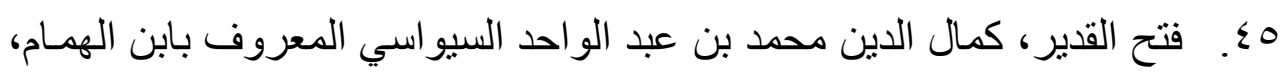
دار الفكر.

7ـ. الفروق = أنوار البروق في أنواء الفروق، أبو العباس شهاب الدين أحمد بن إدريس بن عبد الرحمن المالكي الثهير بالقر افي، عالم الكتب.

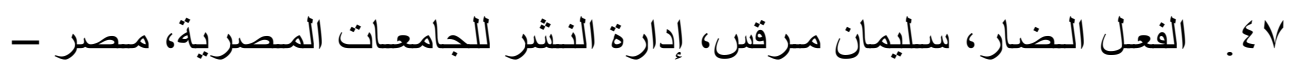

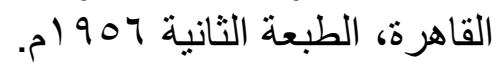

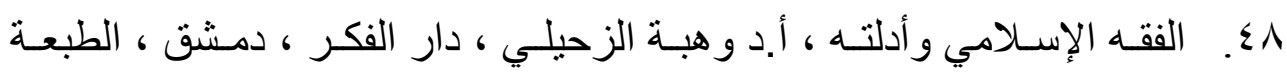

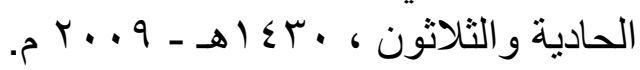

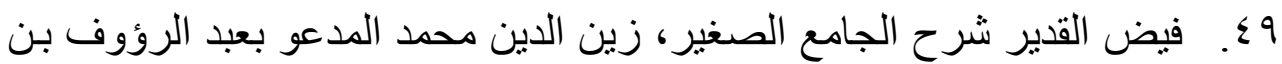

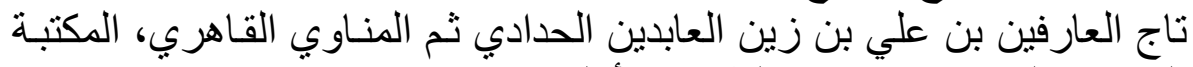

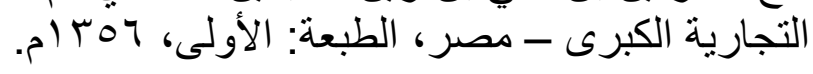

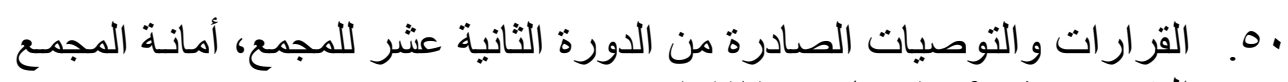

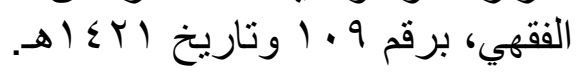

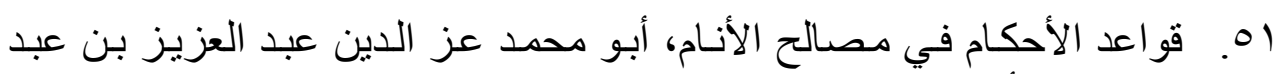

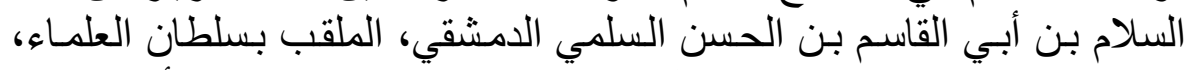

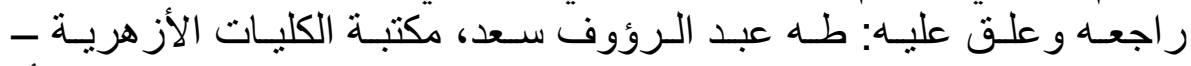

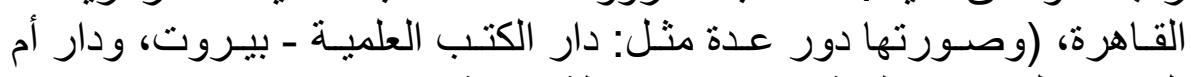

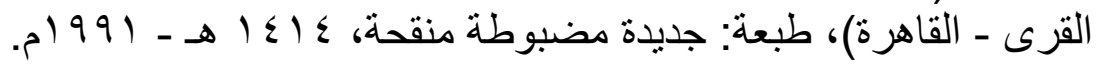

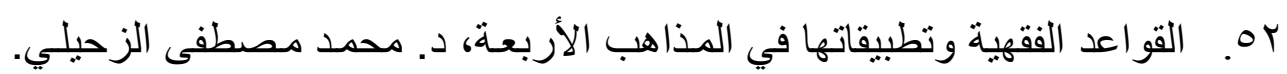

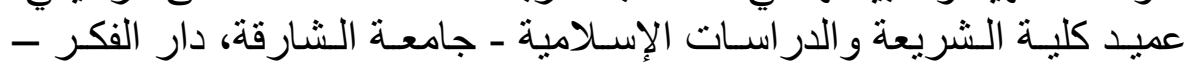

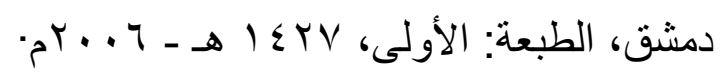

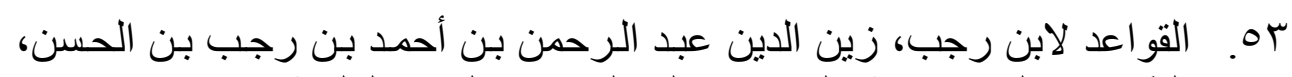

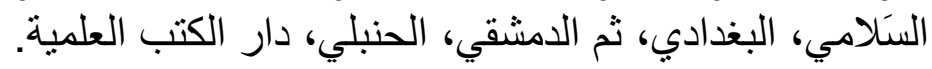

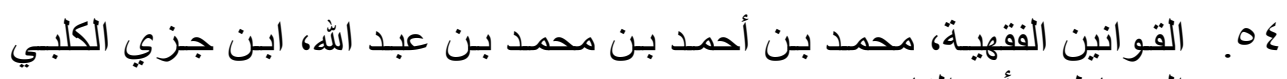

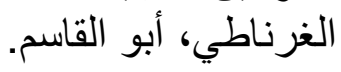




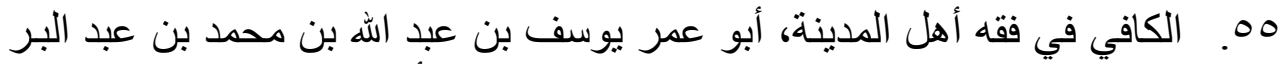

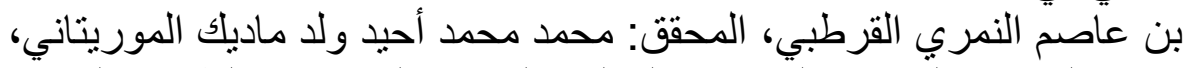
مكتبة الرياض الحديثة، الرياض، المملكة العربية السعودية، الطبعة: الثانية،

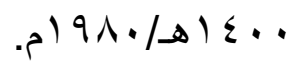

07. كتاب التعريفات، علي بن محمد بن علي الزين الشريف الجرجاني، المحقق:

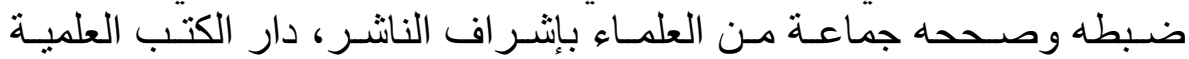

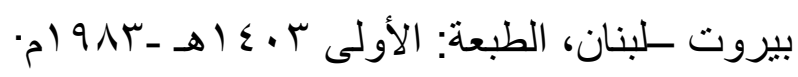

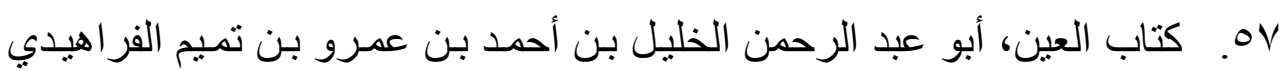

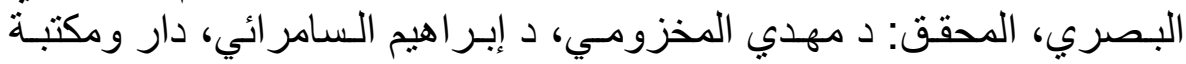

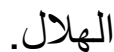

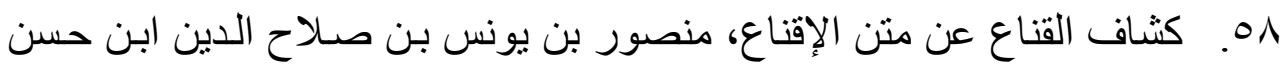
بن إدريس البهوتى الحنبلي، دار الكتب العلمية.

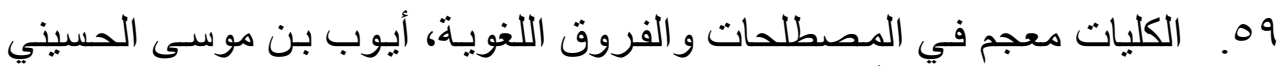

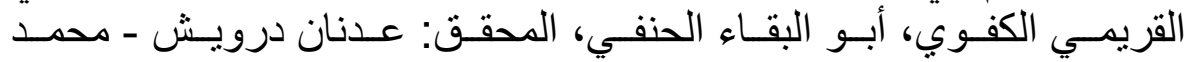

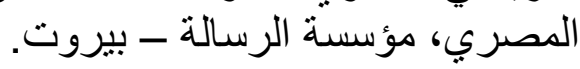

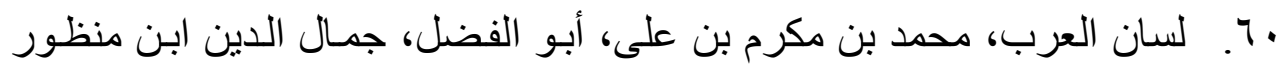

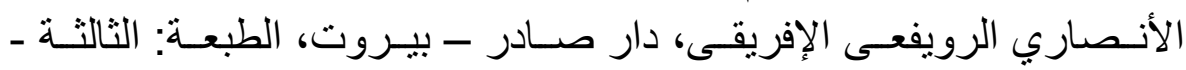

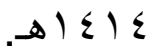

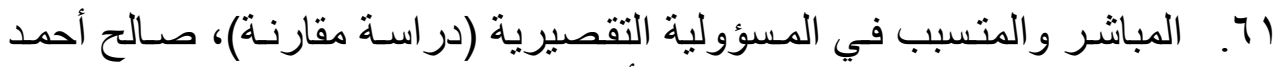

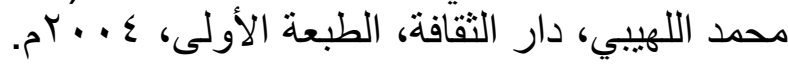

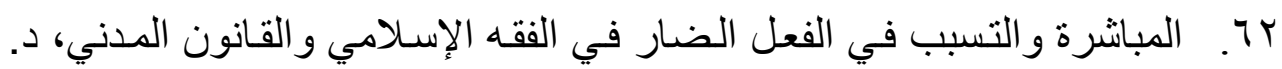

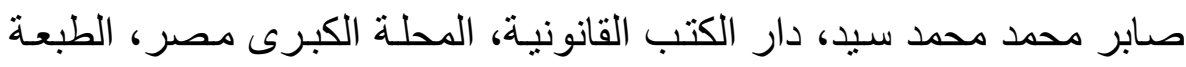

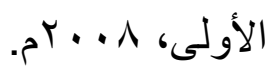

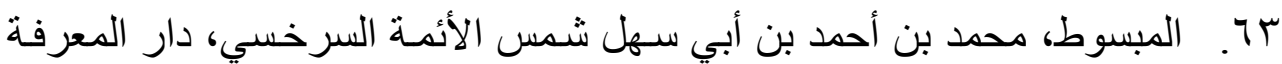

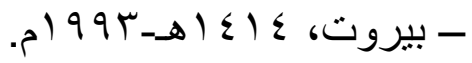

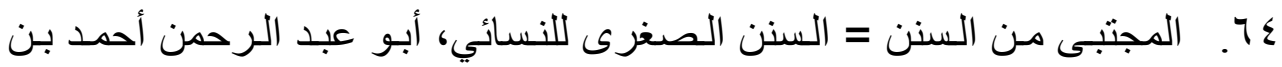

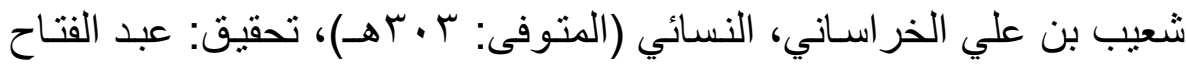

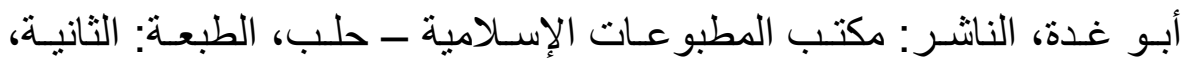

$$
\text { م) } 917-8 \text { - } 18.7
$$

70. مجلة البحوث الفقهية المعاصرة، مسائل في الفقه، العدد الثنامن عشر. 
77 7. مجمع الضمانات، أبو محمد غـانم بـن محمد البغدادي الحنفي، دار الكتـاب

الإسلامين.

V7. مجمل اللغة لابن فارس، أحمد بن فـارس بن زكريـاء القزويني الرازي، أبو

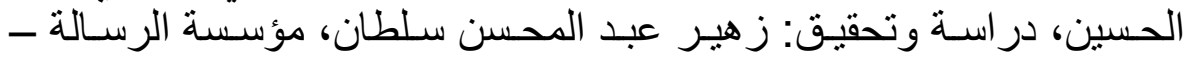

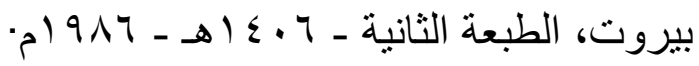

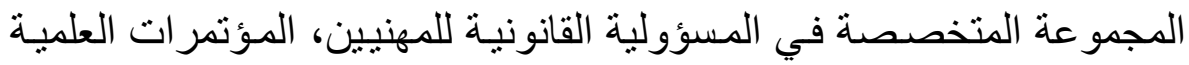

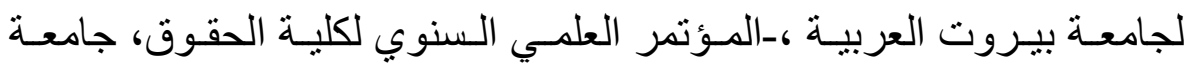

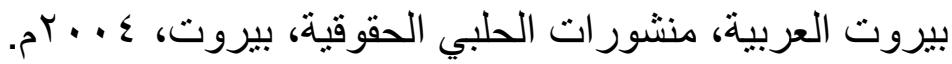
97. المدخل الفقهي العام، مصطفى أحمد الزرقا، دار القلم، دمثق، الطبعة الثالثة،

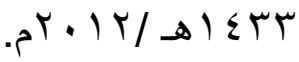

• .

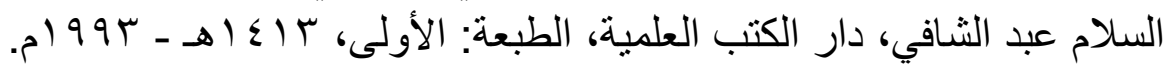

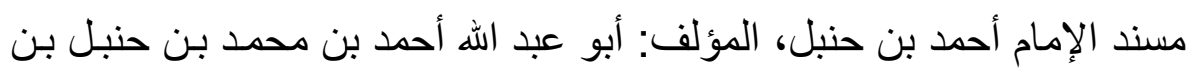

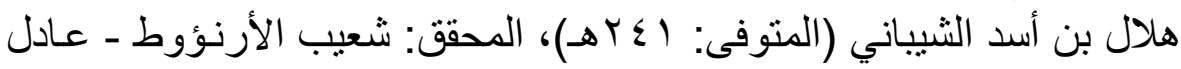

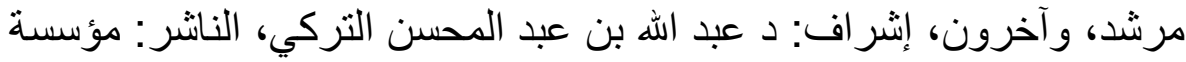

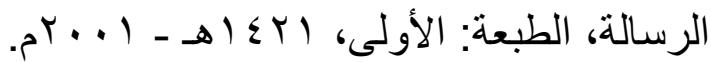

VY المسند الصحيح المختصر بنقل العدل عن العدل إلى رسول الله صلى الله عليه

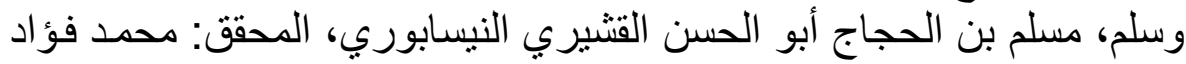

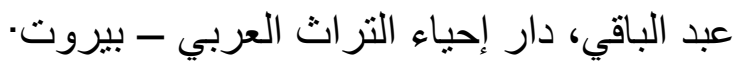

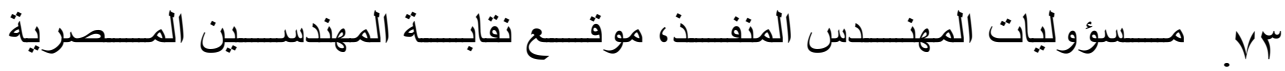
http://eea.org.eg/default.aspx

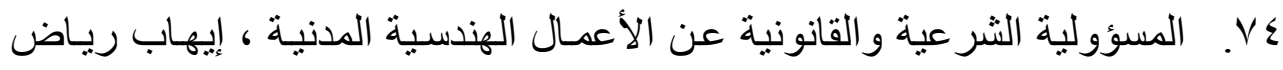

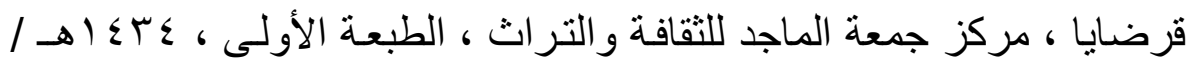

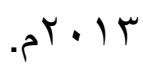

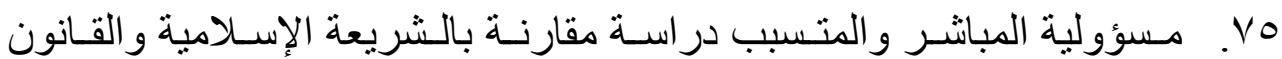

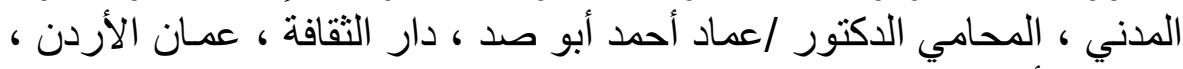

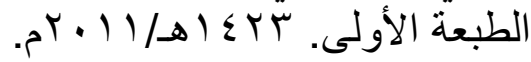

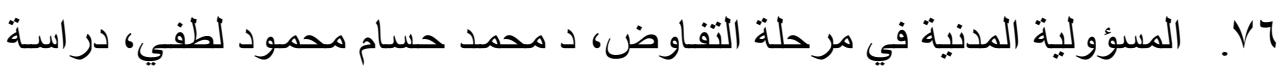
مقارنة في القانونين المصري مرحي و الفرنسي القاهرة، 990 ام. 


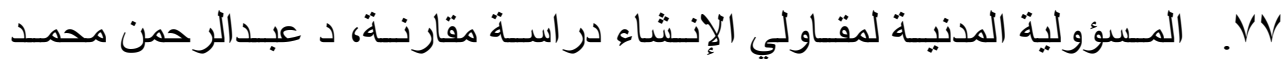

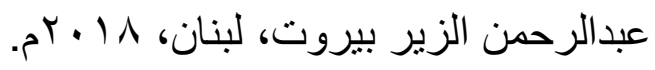

V^. مسؤولية المهندس الاستشاري و المقاول في مجال العقود المدنية وعقد تسليم

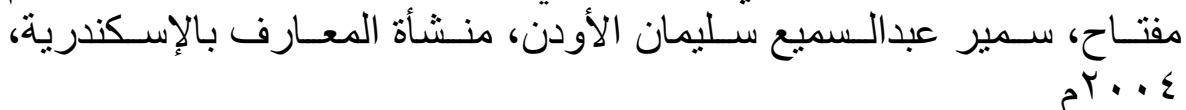

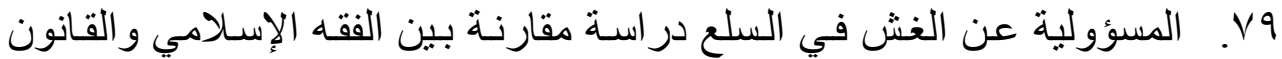

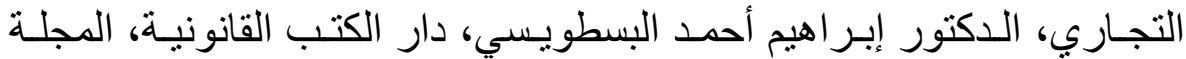

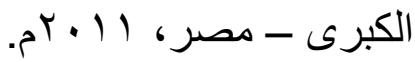

•^. . مصادر الالتزام ، د.عبدالمنعم فرج الصده، دار النهضة العربية، 979 (م.

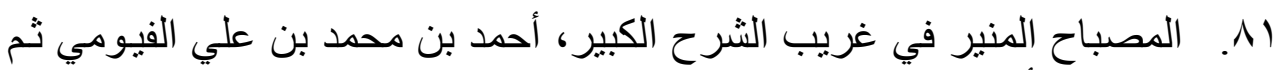

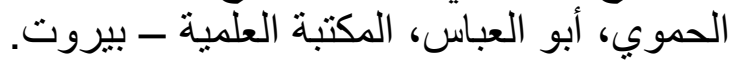

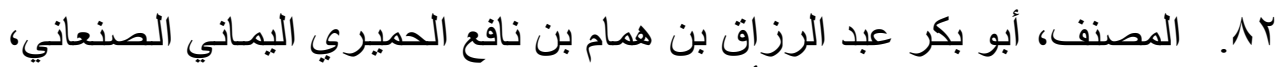

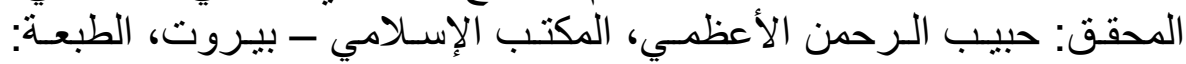
الثانية، ب + الهـ الهـ

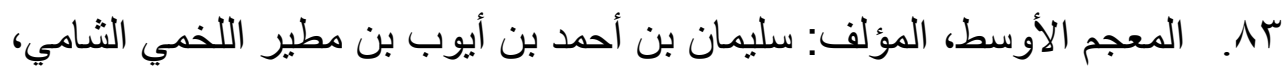

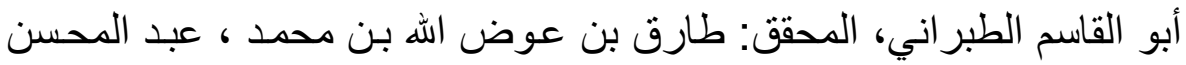
بن إير اهيم الحسيني، دار الحرمين - القاهرة.

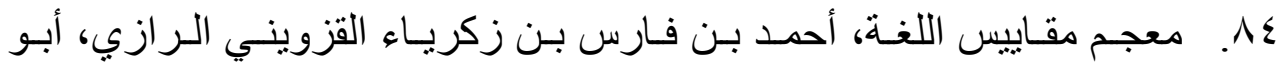

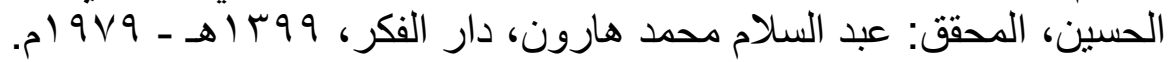

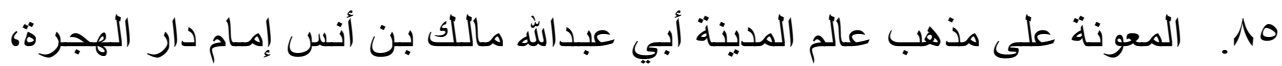

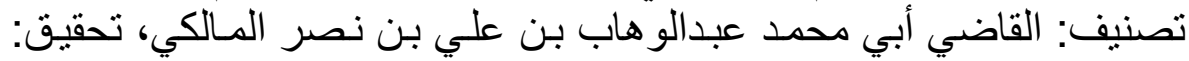

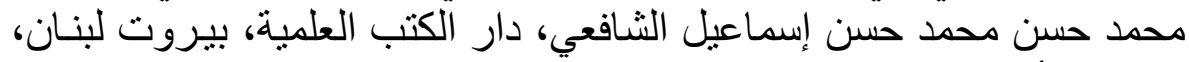

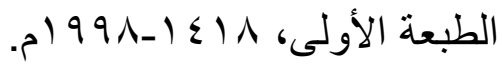

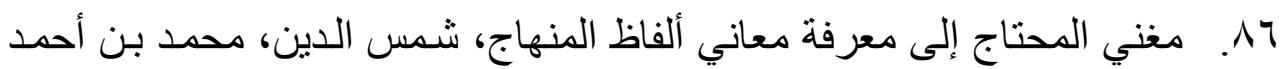

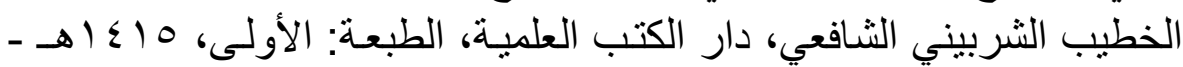
.م) $99 \leq$

AV

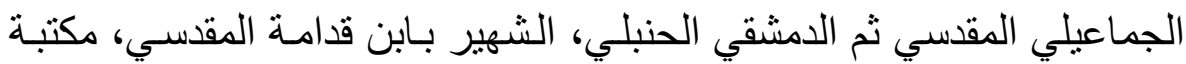
القاهرة.

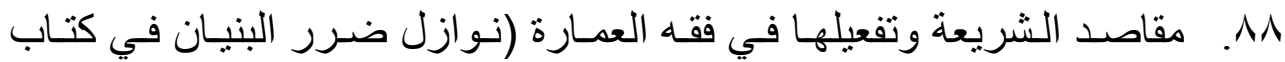

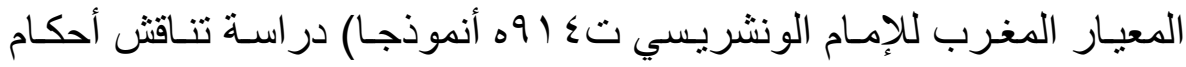


البنيان و آثنار ها ومقاصها وسبل تفعيلها في الأبنية المعاصرة، الدكتور حسني

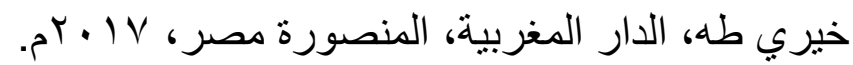

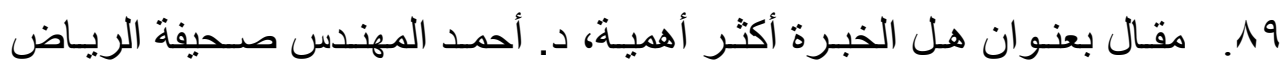

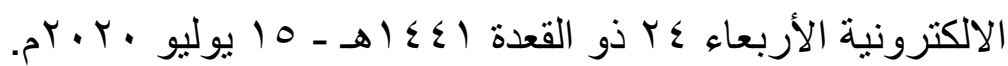

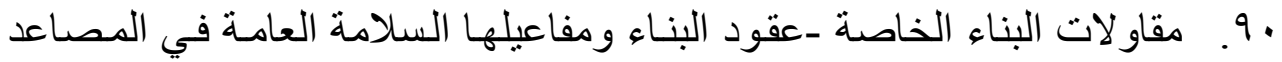

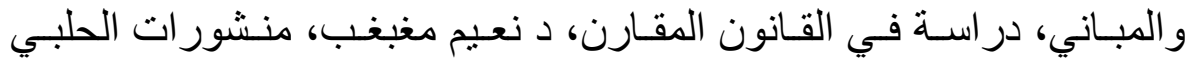

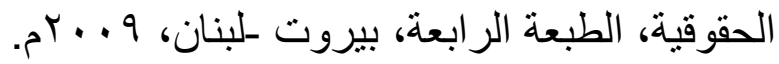
منح الجليل شرح مختصر خليل، محمد بن أحمد بن محمد عليش، أبو عبد الله .91

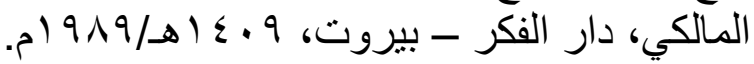

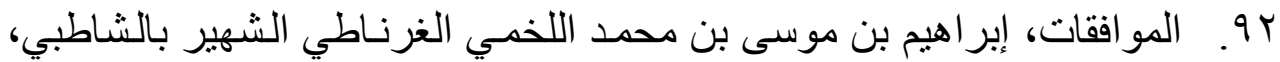

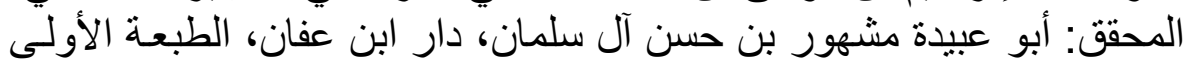

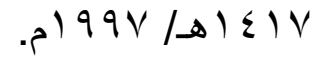

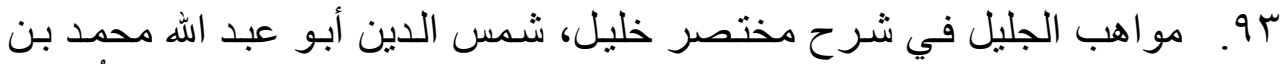

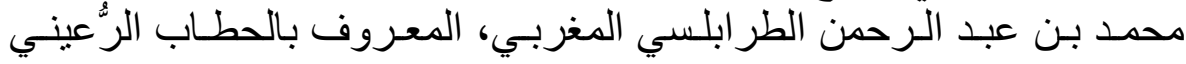

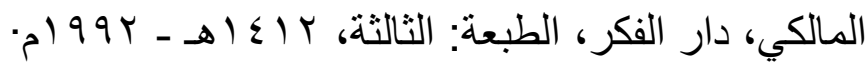

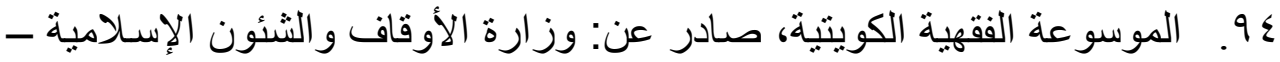

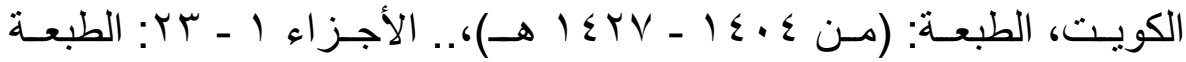

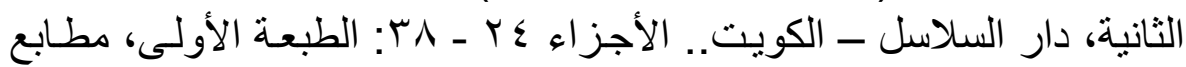

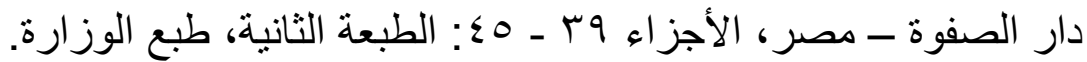
90. الموطأ، مالك بن أنس بن مالك بن عامر الأصبحي المدني، المحقق: محمد

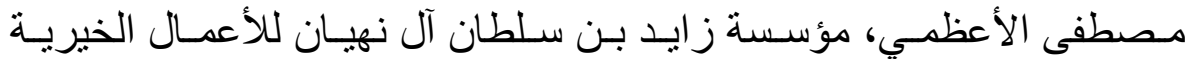

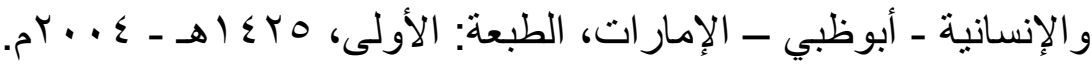

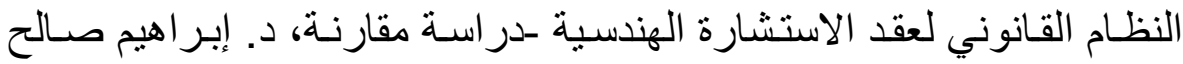

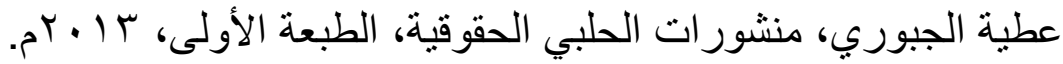
9V. النظريـات الفقهيـة، فتحسي الدريني، جامعـة الحقوق، كليـة الشريعة، الطبعـة الثانية.

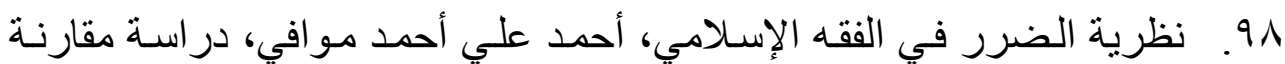

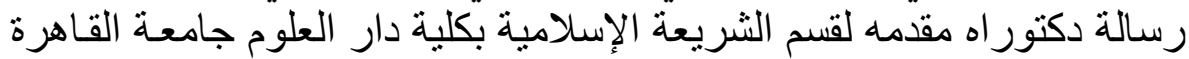

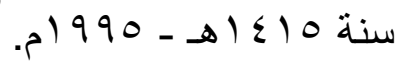

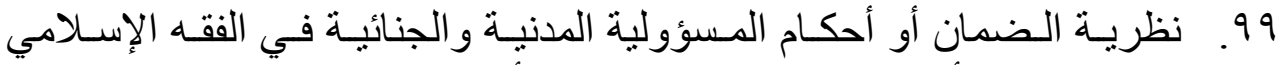

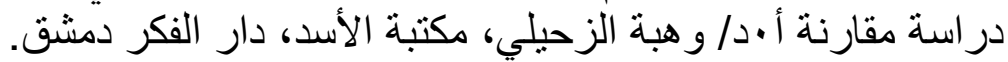


. . . . نظرية الضمان في الفقه الإسلامي العام، د. محمد فوزي فيض الله، بمكتبـة

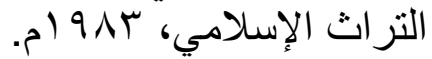

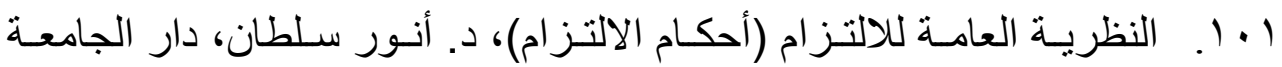

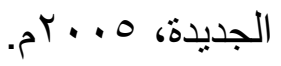

r ـ 1. النظرية العامـة للالتزام، وفقا للقانون الكويتي، د عبد الحي حجازي، سـنة

$$
\text { 6) } 91 \text {. }
$$

ץ. 1. الو افي في شرح القانون المدني، د.سليمان مرقس، الطبعة السادسة.

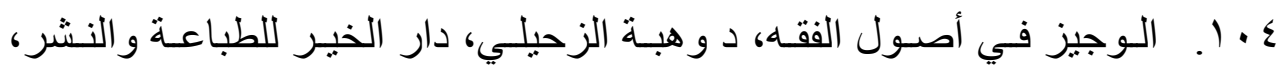
دمشق، سوريا.

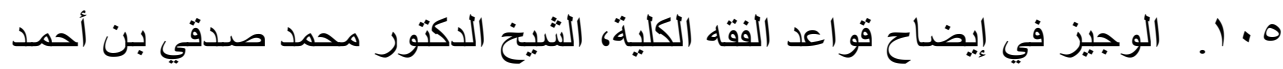

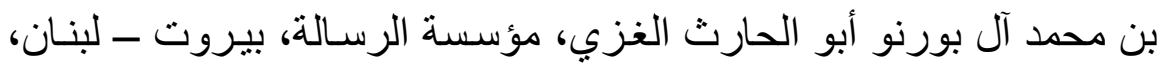

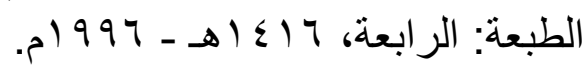
ج • 1. الـوجيز في شـرح القـانون المـدني الأردنـي، ياسـين محمد الجبـوري، دار

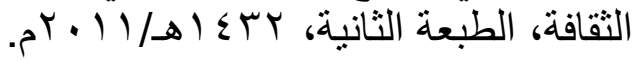

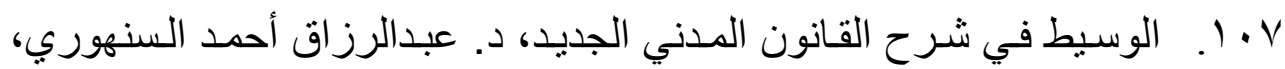

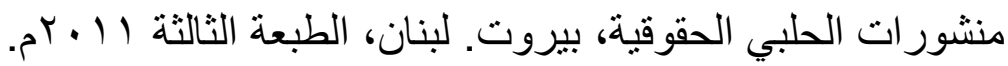

1 • . . الوسيط في شرح القانون المدني مصادر الالتزامات و أحكامها در اسة مقارنة

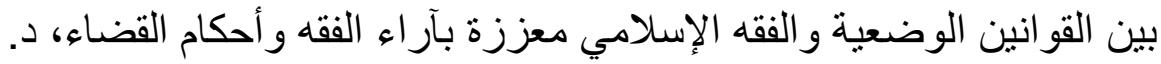

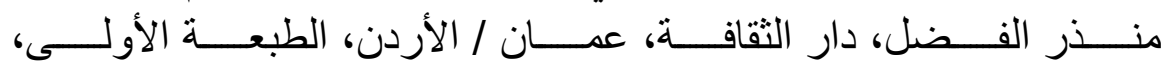

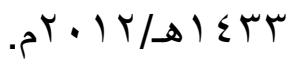
https://www.alukah.net/culture/0/103098/\#ixzz6S5 .1.9 dS6pbo اللوائح والأنظمة:

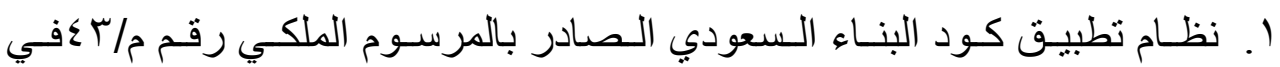
.0) $\leqslant \pi N / \varepsilon / T T$

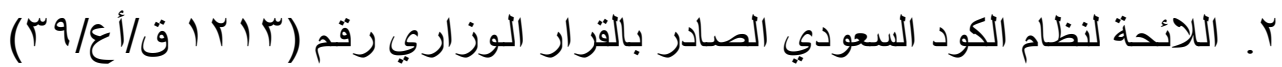

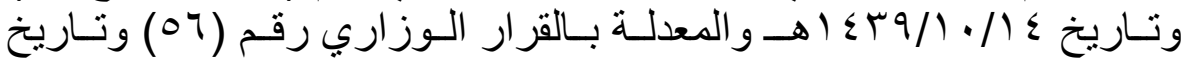




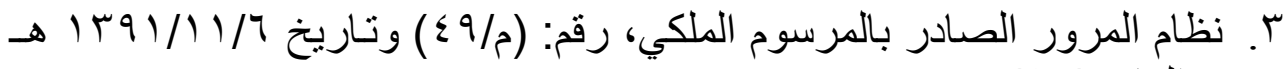

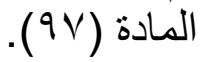

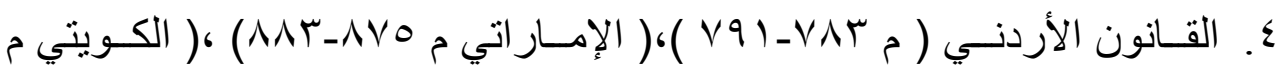
. (7V・--7T7

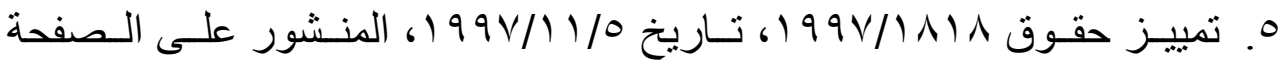

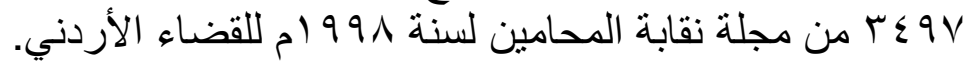

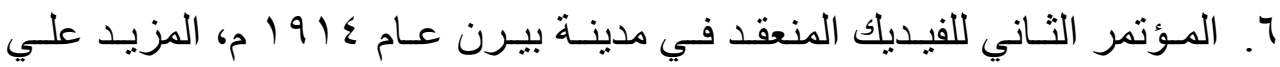

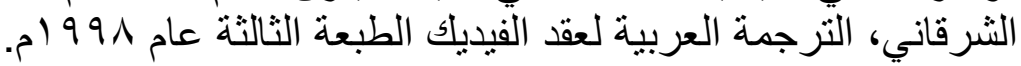

